\title{
ESTIMATIVA DA FLUÊNCIA DE GEOTÊXTEIS NÃO TECIDOS DE POLIÉSTER POR MEIO DE ENSAIOS CONVENCIONAIS E ACELERADOS
}

\author{
Lucas Deroide do Nascimento
}

Engํㅡㄹ Civil, Escola de Engenharia de São Carlos - USP, 2012

\begin{abstract}
Dissertação apresentada à Escola de Engenharia de São Carlos da Universidade de São Paulo, como parte dos requisitos para obtenção do título de Mestre em Ciências, Programa de PósGraduação em Geotecnia.
\end{abstract}

Área de Concentração: Geotecnia

ORIENTADOR: Prof. Dr. Jefferson Lins da Silva

\author{
São Carlos - SP \\ 2015
}

Versão corrigida

Original se encontra disponível na Unidade que aloja o Programa 
AUTORIZO A REPRODUÇÃO TOTAL OU PARCIAL DESTE TRABALHO POR QUALQUER MEIO CONVENCIONAL OU ELETRO̊NICO, PARA FINS DE ESTUDO E PESQUISA, DESDE QUE CITADA A FONTE.

Nascimento, Lucas Deroide do
N244e Estimativa da fluência de poliéster por meio de ensaios convencionais e acelerados / Lucas Deroide do Nascimento; orientador Prof. Jefferso Lins da Silva. São Carlos, 2015.

Dissertação (Mestrado) - Programa de Pós-Graduação e Area de Concentração em Geotecnia -- Escola de Engenharia de São Carlos da Universidade de São Paulo, 2015 .

1. Geotêxteis não tecidos. 2. Fluência. 3. Ensaios acelerados. 4. Stepped sorhermal method. I. Título. 


\section{FOLHA DE JULGAMENTO}

Candidato: Engenheiro LUCAS DEROIDE DO NASCIMENTO.

Título da dissertação: "Estimativa da fluência de geotêxteis não tecidos de poliéster por meio de ensaios convencionais e acelerados".

Data da defesa: 19/10/2015

Comissāo Julgadora:

Resultado:

Prof. Dr. Jefferson Lins da Silva (Orientador)

(Orientador)

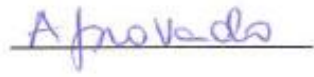

(Escola de Engenharia de São Carlos/EESC)

Profa. Dra. Delma de Mattos Vidal

(Instituto Tecnológico de Aeronáutica/ITA)

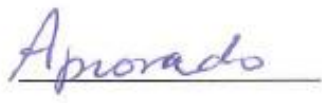

Profa. Dra. Karla Maria Wingler Rebelo

(Universidade Federal do Espírito Santo/UFES)

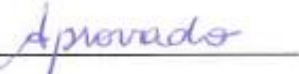

Coordenador do Programa de Pós-Graduação em Geotecnia:

Prof. Dr. Edmundo Rogério Esquivel

Presidente da Comissão de Pós-Graduação:

Prof. Associado Paulo César Lima Segantine 
“Não receie crescer devagar; só tenha medo de permanecer imóvel." (Proverbio chinês) 
Muito especialmente, desejo agradecer ao meu orientador Prof. Dr. Jefferson Lins da Silva, pela disponibilidade, atenção dispensada, paciência, dedicação e profissionalismo ... um Muito Obrigado.

À minha família, em particular, aos meus pais Carlos e Maria Inês, ao meu irmão Eduardo pelo zelo, investimento, confiança e apoio incondicional, e a minha namorada Mirela pelo carinho. Muito obrigado por sempre acreditarem em mim, e ensinarem que o conhecimento é o maior e melhor bem adquirido pelo homem.

Aos técnicos do Laboratório de Geossintéticos da EESC-USP, Clever, Thiago, Manuel e Walter, pelas brincadeiras descontraídas e conhecimentos transmitidos.

As empresas Ober Geossintéticos e Bidim - Mexichem pela doação dos geotêxteis.

Ao CNPq pela bolsa de estudos.

À FAPESP pelos recursos disponibilizados ao longo do mestrado.

$\mathrm{O}$ meu profundo e sentido agradecimento a todas as pessoas que contribuíram para a concretização desta tese, estimulando-me intelectual e emocionalmente.

Espero que esta etapa, que agora termino, possa de alguma forma, retribuir e compensar todo o carinho, apoio e dedicação que, constantemente, me ofereceram. A todos, dedico este trabalho.

Lembrando que ninguém vence sozinho, e que a alegria desta experiência é fruto de muito suor e dedicação. 


\section{SUMÁRIO}

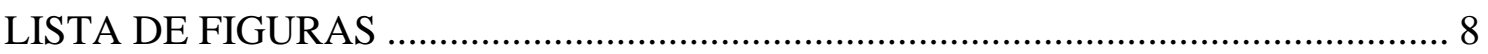

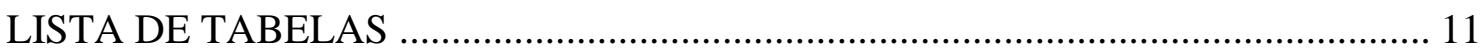

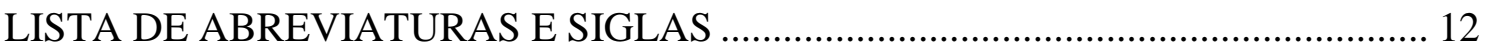

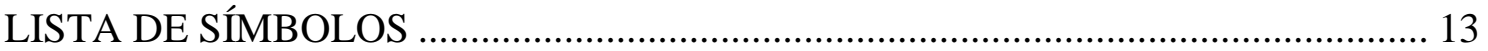

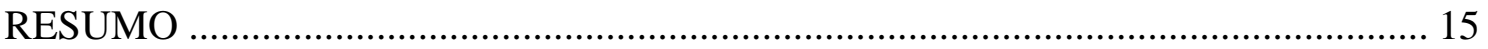

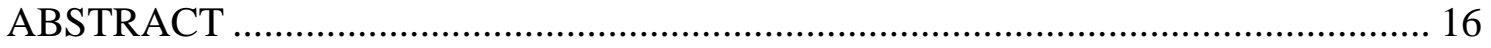

1. INTRODUÇÃ

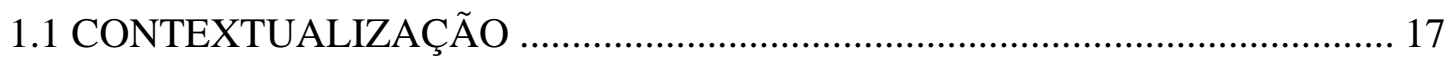

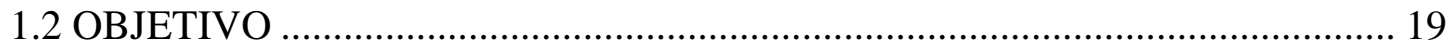

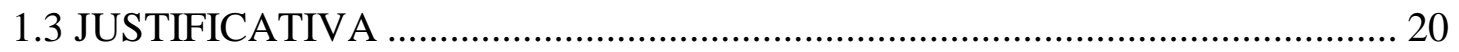

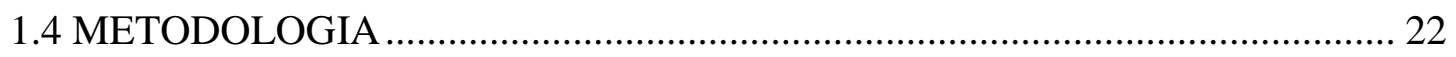

1.5 ORGANIZAÇÃO DA DISSERTAÇÃO ....................................................... 23

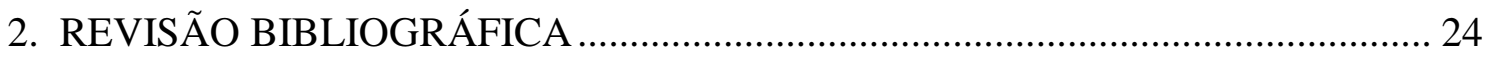

2.1 FLUÊNCIA EM GEOTÊXTEIS _................................................................. 24

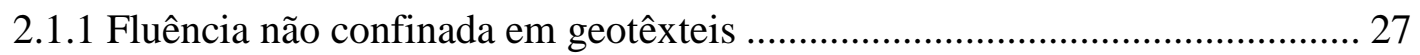

2.1.2 Fluência confinada em geotêxteis ........................................................... 41

2.2 MODELOS DE DEFORMAÇÃO .................................................................. 44

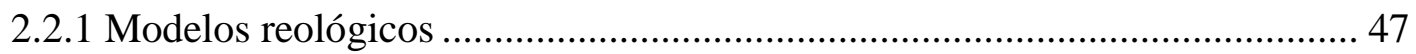

2.2.2 Equação de Arrhenius e equação de Williams-Landel-Ferry......................... 52

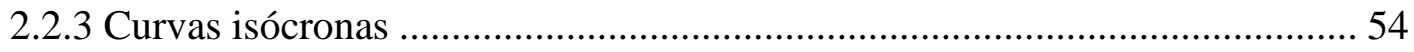

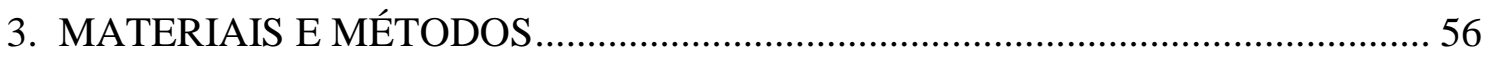

3.1 CARACTERIZAÇÃO DOS GEOTÊXTEIS NÃO TECIDOS ............................ 56

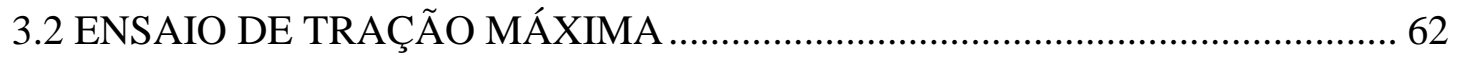

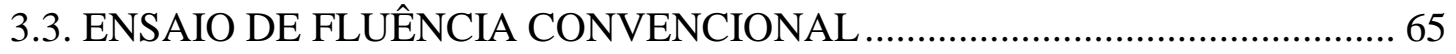

3.4 ENSAIO DE FLUÊNCIA ACELERADA (MÉTODO SIM) .............................. 68

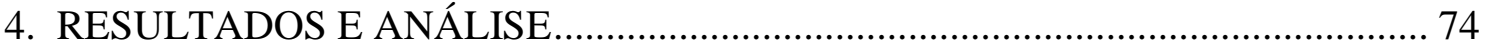


4.1. GEOTÊXTIL DE FILAMENTO CONTÍNUO

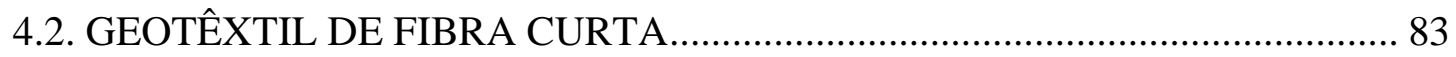

4.3. ESTADO LIMITE DE SERVIÇO ................................................................ 93

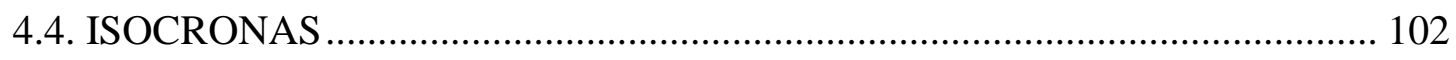

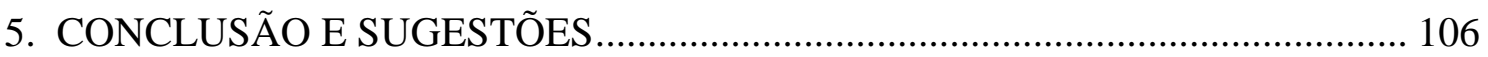

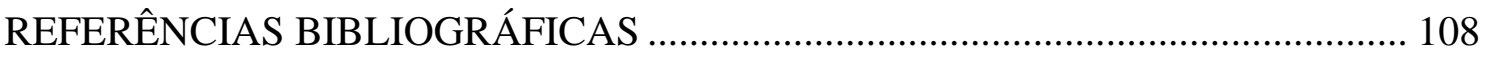




\section{LISTA DE FIGURAS}

Figura 2-1 - Fluência de polímeros com carregamento a $20 \%$ da resistência a tração. Fonte: DEN HOEDT (1986) 26

Figura 2-2 - Curva Típica de Fluência em geotêxteis. Fonte: REDDY \& BUTUL (1999). 29

Figura 2-3 - Fator de translação versus temperatura. Fonte: FARRAG (1998). 30

Figura 2-4 - Comportamento Viscoelástico Linear. 31

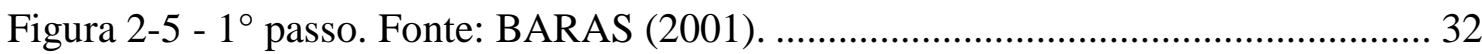

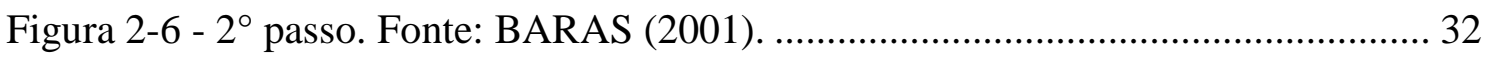

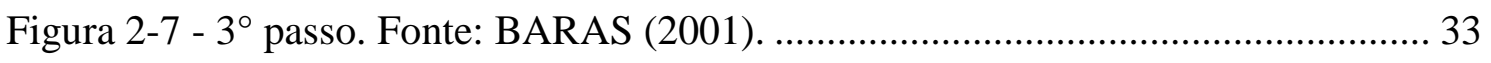

Figura 2-8 - $4^{\circ}$ e $5^{\circ}$ passos. Fonte: BARAS (2001). .................................................... 33

Figura 2-9 - Ensaio convencional, geotêxtil de polipropileno. Fonte: BARAS (2001). 34

Figura 2-10 - Ensaio convencional, geotêxtil de poliéster. Fonte: BARAS (2001),...... 35

Figura 2-11 - Ensaio acelerado, geotêxtil de polipropileno. Fonte: BARAS (2001).... 35

Figura 2-12 - Ensaio acelerado, geotêxtil de poliéster. Fonte: BARAS (2001)............. 35

Figura 2-13 - Fluência geotêxtil de polipropileno. Fonte: COSTANZI (2003). ............ 37

Figura 2-14 - Fluência geotêxtil de poliéster. Fonte: COSTANZI (2003).................... 37

Figura 2-15 - Ruptura por fluência, polipropileno. Fonte: COSTANZI (2003)............. 38

Figura 2-16 - Ruptura por fluência, poliéster. Fonte: COSTANZI (2003)..................... 39

Figura 2-17 - Definição de falha por fluência. Fonte: Zornberg (2004)........................ 40

Figura 2-18 - Equipamento desenvolvido por COSTA (2004). .................................... 41

Figura 2-19 - Comparação entre fluência confinada e não confinada. Fonte: COSTA

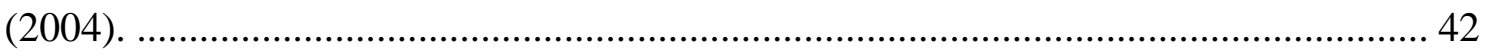

Figura 2-20 - Equipamento desenvolvido por FRANÇA (2012), .................................. 43

Figura 2-21 - Ensaio geotêxtil poliéster, FRANÇA et. al. (2011)................................. 43

Figura 2-22 - Elemento com característica elástica.................................................... 45

Figura 2-23 - Elemento com característica viscosa...................................................... 46

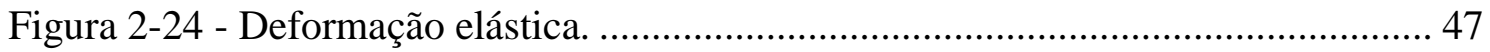

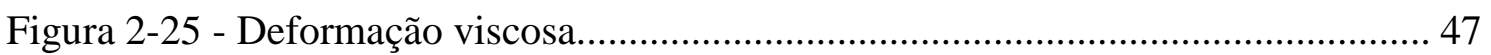

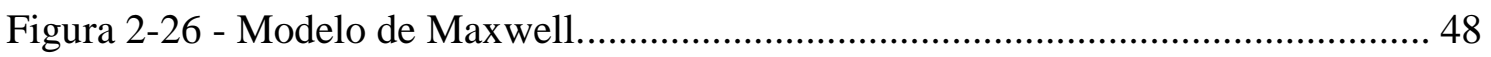

Figura 2-27 - Diagrama básico do modelo de kelvin. Fonte: YEO (2007)................... 48

Figura 2-28 - Comportamento segundo modelo de VOIGT ........................................ 49 
Figura 2-29 - Modelo reológico Kelvin-Chain. Fonte: KOERNER (2001).

Figura 2-30 - a) tempo-deformação; b) deformação-carregamento aplicado (isócrona).55

Figura 3-1 - Equipamento utilizado para obter a carga de ruptura, INSTRON. 63

Figura 3-2 - Coeficiente de variação nos resultados dos ensaios dos geotêxteis........... 65

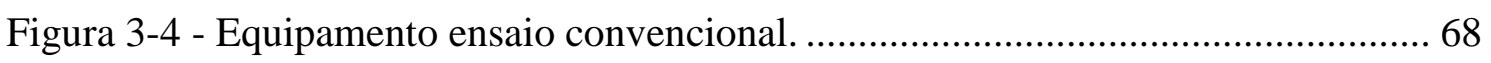

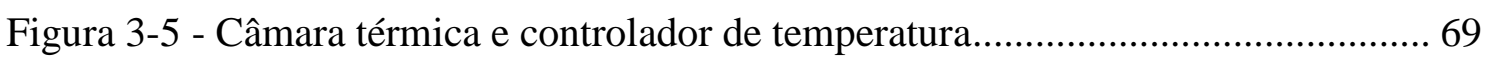

Figura 3-6 - Câmara térmica e controlador de temperatura............................................ 70

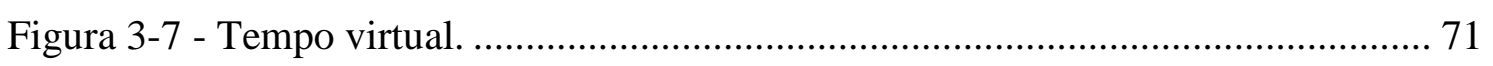

Figura 3-8 - Ajuste do eixo das abcissas. .................................................................... 72

Figura 3-9 - Curva final de fluência. .......................................................................... 73

Figura 4-1 - GTnwL - 5\%, a) Ensaio Convencional, b) SIM - Tempo Virtual, SIM Curva Final.

Figura 4-2 - GTnwL - 10\%, a) Ensaio Convencional, b) SIM - Tempo Virtual, SIM Curva Final.

Figura 4-3 - GTnwL - 20\%, a) Ensaio Convencional, b) SIM - Tempo Virtual, SIM Curva Final.

O alcance das curvas de fluência pelo método idealizado por Thornton foi de 24 a 168 anos.

Figura 4-4 - GTnwL - 40\%, a) Ensaio Convencional, b) SIM - Tempo Virtual, SIM Curva Final. 80

Figura 4-5 - GTnwL - 60\%, a) Ensaio Convencional, b) SIM - Tempo Virtual, SIM Curva Final.

Figura 4-6 - GTnwS - 50\%, a) Ensaio Convencional, b) SIM - Tempo Virtual, SIM Curva Final.

Figura 4-7 - GTnwS - 10\%, a) Ensaio Convencional, b) SIM - Tempo Virtual, SIM Curva Final. 86

Figura 4-8 - GTnwS - 20\%, a) Ensaio Convencional, b) SIM - Tempo Virtual, SIM Curva Final. 88

Figura 4-9 - GTnwS - 40\%, a) Ensaio Convencional, b) SIM - Tempo Virtual, SIM Curva Final.

Figura 4-10 - GTnwS - 60\%, a) Ensaio Convencional, b) SIM - Tempo Virtual, SIM Curva Final. 91

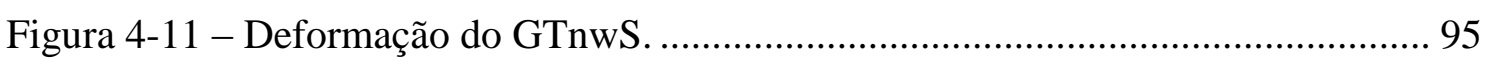

Figura 4-12 - Deformação do GTnwL................................................................ 95 


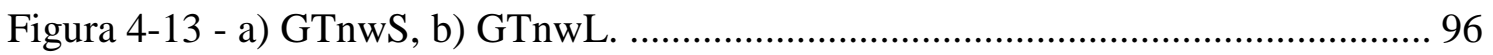

Figura 4-13 - Coeficiente de variação - a) GTnwL, b) GTnwS................................. 101

Figura 4-14 - Módulo de deformação - GTnwS. ........................................................ 102

Figura 4-15 - Módulo de deformação - GTnwL...................................................... 103

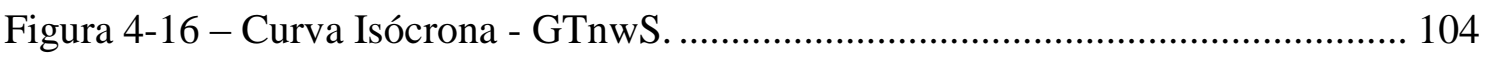

Figura 4-17 - Curva Isócrona - GTnwL.................................................................. 105 


\section{LISTA DE TABELAS}

Tabela 2-1 - Fatores de redução devido a fluência. Fonte: COSTANZI (2003)............ 40

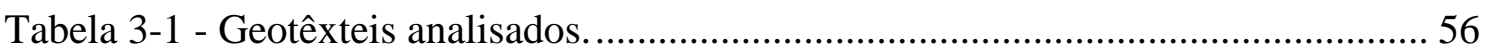

Tabela 3-2 - Espessura e massa por unidade de área - GTnwS. ….............................. 57

Tabela 3-3 - Espessura e massa por unidade de área - GTnwL................................... 58

Tabela 3-4 - Ensaio GRAB para GTnwS PET, segundo a ASTM D 4632 (2008). ....... 59

Tabela 3-5 - Ensaio GRAB para GTnwL PET, conforme a ASTM D 4632 (2008)...... 59

Tabela 3-6 - Ensaio de Puncionamento Estático, de acordo com a NBR 13359 (1993). 60

Tabela 3-7 - Punção de GTnw PET, segundo norma ASTM D 4833 (2000)................ 61

Tabela 3-8 - Resistência ao Rasgo, de acordo com a ASTM D 4533 (1991).................. 62

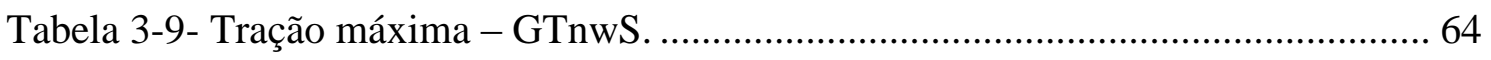

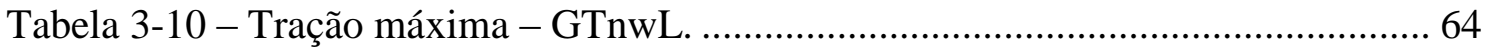

Tabela 4-1 - Coeficientes das curvas pelo método SIM do GTnwL. ............................. 83

Tabela 4-2 - Coeficientes das curvas pelo método SIM, fibra curta. ............................. 92

Tabela 4-3 - Resultados de alongamento (cm) de fluência do GTnwS. ........................ 98

Tabela 4-4 - Resultados de deformação por fluência (\%) do GTnwS. .......................... 98

Tabela 4-5 - Resultados de alongamento (cm) de fluência do GTnwL........................ 99

Tabela 4-6 - Resultados de deformação por fluência (\%) do GTnwL......................... 100 


\section{LISTA DE ABREVIATURAS E SIGLAS}

ABNT

ASTM

EESC

USP

NBR

WLF

PET

PP

PE

PA

C.V.

SIM

ISO
Associação Brasileira de Normas Técnicas

American Society for Testing and Materials

Escola de Engenharia de São Carlos

Universidade de São Paulo

Norma Brasileira

Equação de Williams, Landel e Ferry (1955)

Poliéster

Polipropileno

Polietileno

Poliamida

Coeficiente de Variação

Stepped Isothermal Method

International Organization for Standardization 


\section{LISTA DE SÍMBOLOS}

fcr

$\mathrm{T}_{\max }$

$\mathrm{Tg}$

$\varepsilon_{(\mathrm{t})}$

$\varepsilon_{\mathrm{i}}$

$\varepsilon_{\mathrm{I}}$

$\varepsilon_{\text {II }}$

$\varepsilon_{\text {III }}$

$\mathrm{t}$

$\alpha_{\mathrm{T}}$

$\mathrm{T}_{0}$

$\mathrm{T}$

$\Delta \sigma$

$\mathrm{T}_{\mathrm{a}}$

F

$\sigma$

E

$\varepsilon$

$\eta$

$\mathrm{E}_{0}$

Eat

$\mathrm{R}$

$\varepsilon_{1}^{\prime}$ e $\varepsilon_{2}^{\prime}$

$\mathrm{C}_{1}$ e $\mathrm{C}_{2}$

Fator parcial de redução de fluência

Tensão máxima de carregamento

Temperatura de transição vítrea

Deformação total

Deformações instantâneas

Deformação por fluência primaria

Deformação por fluência secundaria

Deformação por fluência terciaria

Tempo

Fator de translação

Temperatura de referencia

Temperatura qualquer do ensaio

Varação de tensão aplicada

Tensão admissível para certo período

Força concentrada aplicada no corpo de prova

Tensão axial do sistema

Módulo de Young do material

Deformação

Viscosidade do material

Módulo de elasticidade do elemento isolado

Energia de ativação

Constante universal dos gases

Taxas de deformação associadas a $\mathrm{T}_{1}$ e $\mathrm{T}_{2}$

Constantes empíricas da Equação de WLF (Williams, Landel e Ferry, 1955)

Q Carregamento aplicado nas isócronas.

$\varepsilon_{1-1}, \varepsilon_{2-2}, \varepsilon \ldots \quad$ Deformações dos corpos de prova para tempos iguais a $\mathrm{T}_{1}, \mathrm{~T}_{2}, \mathrm{~T}$.

$\mu \quad$ Média

$v \quad$ Coeficiente de variação das amostras

$\mathrm{F}_{\text {máx, long }} \quad$ Força concentrada máxima aplicada no sentido longitudinal da amostra

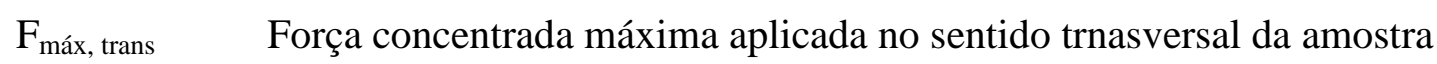


${ }^{\circ} \mathrm{C}$

$\mathrm{P}_{\mathrm{Tx}}$

$\mathrm{P}_{\mathrm{tx}}$

$\mathrm{P}_{\mathrm{t}(\mathrm{x}-1)}$

$\mathrm{P}_{\mathrm{T}(\mathrm{x}-1)}$

$\mathrm{F}_{\mathrm{t}}$

Y

a

b

$\mathrm{R}^{2}$

$\operatorname{LOG}(\mathrm{t})$

$\varepsilon_{\text {inicial }}$

$\varepsilon_{100 \mathrm{anos}}$

$F_{R}$

$\mathrm{T}_{\mathrm{a}}$

$\mathrm{T}_{\mathrm{t}}$

$\mathrm{F}_{\mathrm{R} f l}$

Def max

$\mathrm{D} e f_{f l}$
Graus Celsius

Translação horizontal para a leitura requerida

Tempo virtual da leitura requerida

Tempo virtual da leitura anterior à requerida

Tempo obtido na translação horizontal a leitura anterior a requerida

Fator de translação

Amostra ensaiada

Coeficiente angular da curva de fluência

Constante da curva de fluência

R quadrado da curva de fluência

Logaritmo do tempo da curva de fluência

Deformação inicial de fluência

Deformação de fluência para período de 100 anos

Fator de redução global

Tração admissível

Tração total

Fator de redução da fluência

Deformação máxima obtida no ensaio de tração faixa larga

Deformação obtida no ensaio de fluência pelo método SIM 
NASCIMENTO, L. D. (2015). Estimativa da fluência de geotêxteis não tecidos de poliéster por meio de ensaios convencionais e acelerados. Dissertação (Mestrado) Escola de Engenharia de São Carlos, Universidade de São Paulo, São Carlos - SP, $112 \mathrm{p}$.

O método convencional de ensaios para a obtenção das curvas de fluência de geossintéticos pode necessitar de períodos de até 10.000 horas. Entretanto, a utilização de ensaios acelerados têm se mostrado bastante eficiente, especialmente para avaliar rapidamente a qualidade do material. Estudos bem sucedidos realizados por diversos autores, utilizaram o método Stepped Isothermal Method (SIM) para acelerar a fluência nos geotêxteis. Neste trabalho, com base neste método foi estimada a fluência de dois geotêxteis com $300 \mathrm{~g} / \mathrm{m}^{2}$ do tipo não tecido de poliéster (PET) de fibra curta e contínua. Neste estudo, foi analisada a fluência causada por carregamentos de 5, 10, 20, 40 e 60\% da carga que causa a ruptura do material. Com base nos resultados conclui-se que os valores de deformação por fluência obtidos são satisfatórios, pois as previsões de alcance de até 355 anos estão próximos aos valores encontrados na literatura internacional. Ainda, para o tempo de 100 anos ficou evidenciado que para o geotêxtil não tecido do tipo PET, de fibra curta ou contínua, o comportamento mecânico do geotêxtil é mais influenciado pela deformação inicial do que pela fluência.

Palavras-chave: geotêxteis não tecidos, fluência, ensaios acelerados, stepped isothermal method. 
NASCIMENTO, L. D. (2015). Creep estimation of geotextiles non-woven polyester by conventional and accelerated tests. Dissertation (MSc.) - Engineering School of São Carlos, University of São Paulo. São Carlos, 108p.

The conventional method of tests to achieve the geosynthetic creep curves may require times of up to 10,000 hours. However, the use of accelerated tests have shown to be very effective, especially for rapidly assessing the quality of the material. Successful studies by various authors used the Stepped Isothermal Method Method (SIM) to accelerate creep in geotextiles. In this work, based on this method was estimated creep of two non-woven geotextiles of polyester with $300 \mathrm{~g} / \mathrm{m}^{2}$, short or continuous fiber. In this study, creep caused by loads of $5,10,20,40$ and $60 \%$ of the rupture load of the material was analyzed. Based on the results, it is concluded that the creep strain values obtained are satisfactory, because up to 355 years range forecasts are close to those found in the literature. Still, for the 100-year time, it became evident that for the nonwoven geotextile type PET with short or continuous fiber, the mechanical behavior of the geotextile is more influenced by the initial deformation than by creep.

Keywords: non-woven geotextile, creep, accelerated test, stepped isothermal method. 


\section{INTRODUÇÃO}

\subsection{CONTEXTUALIZAÇÃO}

Geotêxteis são materiais sintéticos que apresentam uma história de aplicação relativamente nova nas obras geotécnicas (Andrawes et al. 1984). Apesar do pouco tempo do uso de geotêxteis se comparado a outros materiais da construção civil, é perceptível um grande aumento de sua utilização no Brasil, principalmente em decorrência das inúmeras possibilidades de emprego do produto, como taludes reforçados, muros de arrimo, contenção de resíduos e aterros, drenagem e filtração, e também pelo caráter econômico associado aos geossintéticos (Elias et al. 2001).

O estudo do comportamento mecânico do geotêxtil aplicado nas obras geotécnicas ao longo de sua vida útil ainda na fase de projeto é de suma importância. Para isto, ensaios como o de tração de faixa larga (ABNT NBR 12824:1993), que determina a resistência à tração não confinada, e o de fluência sob tração não confinada (ABNT NBR 15226:2005), que determina o desempenho em deformação e na ruptura, entre outros; são comumente realizados para uma adequada caracterização física e avaliação do comportamento mecânico do material.

Por ser um material polimérico, e estar submetido a esforço de tração em toda a sua vida útil, no geotêxtil atua um fenômeno físico denominado de fluência, o qual pode causar danos ao sistema estrutural correspondente. Segundo Koerner (1988): "fluência é a deformação de um material quando submetido a um carregamento constante".

Para o estudo da fluência nos geotêxteis, alguns ensaios são considerados bem simples, um deles é o ensaio de fluência não confinada convencional. Costa (1999) descreve com clareza a simplicidade de montagem e os equipamentos necessários para o emprego deste ensaio. Uma desvantagem do ensaio convencional é o fator tempo, pois estas técnicas demandam ensaios de 1000 até 10000 horas, conforme a ABNT NBR 15226:2005.

Em contrapartida ao longo tempo dos ensaios convencionais, uma técnica que vem ganhando grande destaque é a utilização de ensaios não confinados acelerados, como o SIM (Stepped Isothermal Method) inicialmente idealizado por Thornton et al. (1998). Isto porque as deformações por fluência podem ser estimadas em intervalos de tempo 
razoavelmente menores, se comparados aos resultados oriundos dos ensaios convencionais, o que facilita a qualidade da extrapolação do ensaio convencional e o controle de qualidade dos produtos para os quais o ensaio acelerado se mostre conveniente.

O método SIM trabalha com o carregamento de uma mesmo corpo de prova que fica exposta ao aumento controlado de temperatura. A base conceitual deste ensaio é o da superposição tempo-temperatura que geram as curvas isócronas, que permitem observar como o geossintético se comporta quando submetido a um carregamento constante, ao longo do tempo. Tais curvas auxiliam no dimensionamento de estruturas de solos reforçados com geotêxteis.

No Brasil, estudos sobre ensaios de fluência convencional e acelerada já foram realizados por Baras (2001) e por Costanzi (2003) para geotêxteis não tecidos, os quais relacionaram comparativamente os resultados obtidos entre os dois tipos de ensaios, e também os fatores de redução da resistência à tração com os dados bibliográficos existentes.

O trabalho de pesquisa proposto pretende analisar a fluência de geotêxteis não tecidos por meio de ensaios de fluência convencionais e acelerados, complementando e aumentando os dados já obtidos por Baras (2001) e por Costanzi (2003), considerando para isto a utilização de um novo equipamento disponível no Laboratório de Geossintéticos do Departamento de Geotecnia da Escola de Engenharia de São Carlos da Universidade de São Paulo.

A fluência estimada pelos dois procedimentos analisados nesta pesquisa tem como objetivo determinar a resistência à tração disponível do geossintético a partir da redução do valor da resistência nominal garantida pelo fabricante por meio do fator de redução total que leva em consideração os processos de degradação a que o geossintético estará submetido, por exemplo: a fluência em tração, os danos mecânicos de instalação e a degradação ambiental (química ou biológica). 


\subsection{OBJETIVO}

O objetivo desta pesquisa é avaliar a fluência de dois tipos de geotêxteis constituídos de poliéster (PET) com estruturas diferentes e massa por unidade de área semelhante por meio de procedimentos convencionais e acelerados com o intuito de contribuir com a questão da fluência apresentada pelos geotêxteis em estruturas de solo reforçado com geotêxteis. Os objetivos específicos da pesquisa são:

- Realizar ensaios para uma adequada caracterização física dos geotêxteis;

- Pretende-se analisar os níveis de carregamento de 5, 10, 20, 40 e 60\% da carga que provoca a deformação por fluência;

- Quantificar a fluência não confinada conforme o procedimento convencional, segundo a norma ISO 13431 (1998) e a ABNT NBR 15226:2005;

- Implementar a utilização de um equipamento novo para a realização de ensaios de fluência acelerada utilizando o método SIM (ASTM D 6992 03);

- Analisar os resultados da fluência convencional e acelerada; considerando a variabilidade da deformação por fluência em tração. 


\subsection{JUSTIFICATIVA}

Uma solução de engenharia geotécnica que apresenta tendência crescente em projetos é a utilização de geossintéticos como material de reforço. Além de reforçar, estes produtos exercem outras inúmeras formas de aplicação e por serem fabricados geralmente estão associados a um rigoroso controle de qualidade.

Os geossintéticos também apresentam um apelo ambiental relevante com a contribuição destes materiais na mitigação dos impactos ambientais e na proteção do meio ambiente. Porem a possibilidade de reciclar o poliéster tem repercussão pequena até porque os produtos reciclados não podem ser aplicados com função de reforço e exigem matéria prima de altíssima qualidade para poderem ser empregados em obras geotécnicas com vida de serviço maior que 5 anos, como é o caso do geotêxtil não tecido de poliéster, material estudado nesta pesquisa.

Por apresentar uma ampla gama de produtos no mercado, o geotêxtil pode apresentar significativas variações em suas características, sendo algumas destas apresentadas com grande relevância no comportamento mecânico de estruturas de solo reforçado. O fenômeno de fluência em materiais viscoelásticos como os geotêxteis deve ser considerado nos projetos geotécnicos.

A incerteza gerada em torno do comportamento de fluência do geotêxtil será a análise de estudo deste trabalho, pois o engenheiro projetista necessariamente deve escolher um valor apropriado para o fator de redução parcial de fluência $\left(\mathrm{FR}_{\mathrm{FL}}\right)$. $\mathrm{O}$ valor adotado pelo engenheiro pode influir diretamente na probabilidade de falha do geotêxtil inserido numa obra geotécnica.

Outro motivo deste estudo é a grande faixa de valores possíveis de utilização em projetos básicos para o fator de redução parcial por fluência. Segundo Vertematti (2004) este fator parcial deve ser utilizado na ausência de indicação do produtor ou de ensaios de fluência realizados por laboratório, com um valor mínimo de 2 e pode chegar a um valor máximo igual a 5, em função do tipo de polímero empregado. Esta variação pode gerar uma redução da resistência a tração do produto que poderá variar de $20 \%$ a $50 \%$ da resistência máxima característica do material. Esta redução influi diretamente no 
valor final da obra, tornando-a mais onerosa ou mesmo mais insegura dependendo do $\mathrm{FR}_{\mathrm{FL}}$ adotado pelo projetista. 


\subsection{METODOLOGIA}

O princípio da dissertação foi composto pela busca de conhecimento através de uma intensa revisão bibliográfica do assunto em questão. $\mathrm{O}$ ponto de partida foi $\mathrm{o}$ entendimento de publicações realizadas por pesquisadores da área de geossintéticos. Em paralelo a isto, foi implementado um novo equipamento para realização de ensaios acelerados de fluência de geossintéticos no Laboratório de Geossintéticos da EESC.

Seguindo o rumo obtido na revisão bibliográfica e definido os materiais ensaiados, foi realizada a caracterização física e mecânica dos geotêxteis estudados para, em seguida, iniciar a parte experimental do trabalho proposto, ou seja, os ensaios convencionais e acelerados de fluência.

A pesquisa bibliográfica foi realizada com o intuito de reunir o maior número possível de resultados de fluência sob tração para os materiais utilizados, visto que, existem poucos dados experimentais na bibliografia brasileira e internacional.

Os resultados obtidos foram analisados por meio da interpretação de modelos reológicos juntamente com as diretrizes indicadas por Thornton et al. (1998), para estimar o comportamento futuro e realístico do geotêxtil.

Os dados existentes na bibliografia foram utilizados como metodologia para desenvolvimento da realização dos ensaios, e por conseguinte, como parâmetro para o interpretar e verificar possível evolução das características resistentes dos materiais. 


\subsection{ORGANIZAÇÃO DA DISSERTAÇÃO}

O texto da dissertação é formado por 5 capítulos. O primeiro capítulo apresenta a introdução e ressalta a importância de novos estudos sobre fluência em geossintéticos, referenciando alguns pesquisadores. O objetivo principal da pesquisa é discutido neste capítulo.

A revisão bibliográfica compõe o segundo capítulo da dissertação, inicialmente é explanado como a fluência age sobre as diferentes características dos geossintéticos. Apresenta-se os ensaios necessários à quantificação das deformações ocorridas por fluência e modelos de cálculo que adequam-se ao cenário proposto.

O capitulo três é uma abordagem direta dos métodos necessários aos ensaios realizados. A caracterização física e mecânica do material é realizada através de procedimentos normativos, utilizando métodos já consagrados no meio científico. Ao final deste capitulo é apresentado o equipamento utilizado para o ensaio de fluência acelerada, bem como o procedimento de cálculo para obtenção do ajuste da curva de deformação deste ensaio.

O quarto capítulo refere-se a aplicação da metodologia de ensaios bem como os resultados encontrados nesta pesquisa. O capítulo é composto por duas partes distintas, inicialmente é exposto os resultados obtidos nos ensaios de fluência, convencional e SIM, para dois diferentes tipos de geotêxteis. Em seguida, a variabilidade dos resultados encontrados é estudada com base em pesquisas anteriores e, realiza-se uma análise com base no estado limite de serviço do material.

O capítulo cinco apresenta as conclusões obtidas através dos estudos de fluência realizados, bem como sugestões e direcionamentos para novas pesquisas. Por fim, são apresentadas as referências bibliográficas. 


\section{REVISÃO BIBLIOGRÁFICA}

Este capítulo tem como objetivo apresentar estudos e resultados anteriores relacionados ao tema desta pesquisa, bem como as metodologias aplicadas e os ensaios realizados. Foi realizado um resumo cronológico dos diferentes ensaios de fluência e também dos procedimentos executados pelos pesquisadores.

Inicialmente são expostos os diferentes geotêxteis existentes e suas características inerentes. Após isto, é demonstrado a evolução do ensaio de fluência e o desenvolvimento de interpretação do ensaio acelerado (FARRAG (1998), THORNTON et al. (1998)) e também é apresentado o ensaio de fluência confinada (COSTA (2004), FRANÇA (2012)).

\subsection{FLUÊNCIA EM GEOTÊXTEIS}

Existem diversos tipos de geossintéticos, entre eles estão os geotêxteis, que são produtos permeáveis que se diferenciam entre si por meio da composição da matéria prima e do processo de fabricação, podem ser composto de fibras cortadas, filamentos contínuos, monofilamentos, laminetes ou fios, segundo a NBR ISSO 2013. Os geotêxteis podem ser tecidos e não tecidos, além desses tipos, de acordo com JOHN (1987) e KOERNER (1994), existe um terceiro tipo, o tricotado.

Os geotêxteis não tecidos apresentam resistência à degradação química e biológica, a esforços de tração e puncionamento e podem ser disponíveis em polipropileno e também em poliéster.

Devido a sua capacidade de permeabilidade, os geotêxteis não tecidos podem ser usados como dreno e filtro, retendo as partículas sólidas e permitindo a passagem dos fluidos, a característica mecânica que o diferencia de outros produtos é a significativa redução de deformação inicial quando confinado, sendo esta redução mais significativa que a deformação por fluência nos produtos submetidos à solicitações em tração distante da condição de ruptura. 
Já os geotêxteis tecidos apresentam boa resistência mecânica com baixa deformação. Este tipo de geotêxtil é indicado para reforço de solo e também como elemento de separação entre solos com diferentes granulometrias, sendo aplicado como filtro quando há interesse de maior rigidez do conjunto.

Segundo BARAS (2001), o geotêxtil quando confinado ganha rigidez e, por se tratar de um material compressível, a fluência é reduzida.

Existem vários fatores que podem influenciar a fluência de geotêxteis não tecidos. Dentre eles, COSTANZI (2003) sugere:

- TIPO DE POLÍMERO: os polímeros apresentam longas cadeias moleculares e complexas formas geométricas.

O comportamento do polímero é estabelecido através de uma relação entre as quantidades de zonas cristalinas e amorfas que o compõe. Os materiais poliméricos, quanto submetidos a cargas ou temperaturas variadas, deformam-se por meio de movimentos moleculares como a distorção do comprimento e dos ângulos das ligações químicas e também pelo rearranjo dos átomos (ROYLANCE, 2001).

O material PET (poliéster), que é o geotêxtil não tecido analisado nesta pesquisa, apresenta-se com cerca de $30 \%$ a $40 \%$ de zonas cristalinas em sua composição. Tais zonas são as responsáveis pela resistência mecânica do material, e isto influencia diretamente na fluência do geotêxtil.

Autores como CAFFUZZI, (1997) e DEN HOEDT, (1986) classificaram o geotêxtil não tecido de poliéster, no estado não confinado, como a deformação por fluência menos variável, isto porque o tipo de formação polimérica nele encontrado apresenta temperatura de transição vítrea bem maior que a temperatura ambiente de utilização (a temperatura de transição vítrea do PET é de aproximadamente $80^{\circ} \mathrm{C}$ ) (Figura 2-1). 


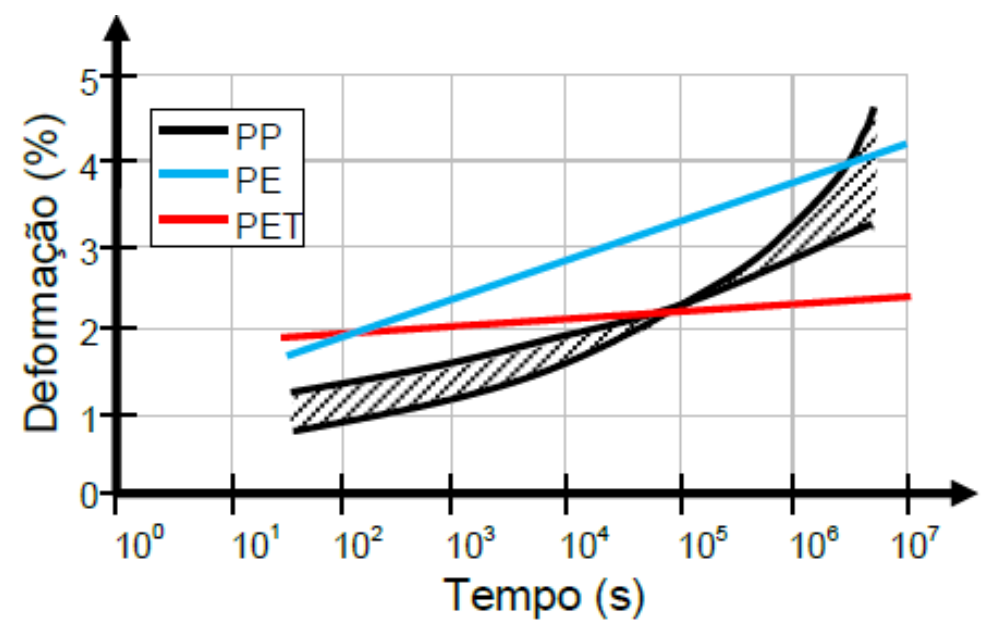

Figura 2-1 - Fluência de polímeros com carregamento a $20 \%$ da resistência a tração. Fonte: DEN HOEDT (1986).

- FORMA DE FABRICAÇÃO: a forma de fabricação do geotêxtil pode influenciar nas deformações por fluência através das diferentes estruturas de composição, e também dos processos de fabricação.

Características como a qualidade da matéria prima de fabricação ou da estrutura final do material influenciam na resposta de fluência do material. Segundo FRANÇA (2012) uma porcentagem da fluência apresentada pelo geotêxtil é devida ao rearranjo estrutural macroscópico regido pelos diferentes graus de liberdade entre as fibras que o compõe.

- TEMPERATURA: a deformação por fluência também é afetado pela temperatura. Em temperaturas abaixo da transição vítrea do polímero, as ligações moleculares como as de hidrogênio ou a de van der Waals são responsáveis por manter as cadeias moleculares ligadas uma a uma, e o geossintético apresenta apenas alongamento destas ligações. A temperatura de transição vítrea (Tg) refere-se à temperatura a qual ocorre uma mudança de fase no material, o material passa de um estado físico sólido para outro estado de mobilidade onde se torna mais deformável (ROYLANCE, 2001). 
- CONFINAMENTO EM SOlOS: estudos de autores como COSTA, (2004); BENJAMIM, (2006) e FRANÇA, (2011) denotam uma diminuição do efeito da fluência em estruturas solo-geotêxtil. Isto acontece porque o solo reduz a liberdade estrutural e o movimento entre as fibras do material, isto quando o solo estiver atuando na zona passiva; para a zona ativa de solicitação, o solo se torna o causador da deformação por imposição de solicitação.

Verifica-se que para geotêxteis não tecidos do tipo PET, o confinamento não influência significativamente a deformação por fluência. Somente as deformações iniciais que apresentam maior redução na fluência (MCGOWN; ANDRAWES; KABIR (1982)).

\subsubsection{Fluência não confinada em geotêxteis}

Segundo ABRAMENTO (1995), define-se fluência em geossintéticos, como a habilidade do corpo em alongar-se, quando submetido à influência de um esforço constante e de longa duração.

Os resultados encontrados a partir de ensaios de fluência em laboratórios auxiliam o engenheiro a ter um melhor entendimento de como a ação das cargas constantes, ao qual o geotêxtil será submetido, geram deformações das fibras dos geotêxteis, podendo afetar a estrutura reforçada através de excesso de deformação ou mesmo falha no sistema (COSTANZI, 2003).

Ensaios de fluência em geotêxteis podem ser realizados pelo método convencional e também pelo acelerado. Os ensaios convencionais não confinados são normatizados pela ABNT (NBR-15226, 2005), e sua realização acontece com temperatura e umidade controladas no laboratório. A determinação do comportamento de deformações por fluência convencional deve ser medida em intervalos de tempo específicos e a carga é mantida constante por um período de 1000 horas até 10000 horas.

Já em ensaios acelerados, os corpos de prova estão submetidos a esforços constantes, nos quais ocorre a variação da temperatura de tempos em tempos. Os resultados e os procedimentos para a realização dos ensaios acelerados podem ser 
baseados na ASTM D5262 (1992). As analises destes resultados e posterior aceitação dos dados está definida na ISO 20432 (2007).

Segundo alguns autores que estudaram o processo de fluência em materiais, como CAZZUFFI et al. (1997) e MSOUTI et al. (1997), a fluência é um fenômeno composto de três fases distintas, no qual o geotêxtil, quando sofre a ação de um carregamento, apresenta uma deformação total $\left(\varepsilon_{(\mathrm{t})}\right)$ composta por um somatório de quatro tipos de deformação. São elas, as deformações do tipo instantâneas $\left(\varepsilon_{i}\right)$, por fluência primaria $\left(\varepsilon_{\mathrm{I}}\right)$, por fluência secundaria $\left(\varepsilon_{\mathrm{II}}\right)$ e por fluência terciaria $\left(\varepsilon_{\text {III }}\right)$, como mostra a Equação (2.1). Esta conclusão também foi adotada por pesquisadores brasileiros, como BARAS (2001) e COSTANZI (2003).

$$
\varepsilon_{(\mathrm{t})=} \varepsilon_{\mathrm{i+}} \varepsilon_{\mathrm{I+}} \varepsilon_{\mathrm{II}+} \varepsilon_{\mathrm{III}}
$$

A deformação instantânea ocorre no momento em que o material sofre o carregamento.

As três fases de deformação por fluência são:

- Fluência primária: ocorre uma rápida deformação, com uma diminuição da taxa de deformação. Quando plotado em um gráfico deformação versus $\log ($ tempo), o trecho tem um comportamento linear;

- Fluência secundária: ocorre uma lenta taxa de deformação decrescente. Quando plotado em um gráfico deformação versus tempo, o trecho tem um comportamento linear;

- Fluência terciária: ocorre um aumento da taxa de deformação seguido da ruptura do material.

A Figura 2-2 demonstra as três fases de deformação e também a taxa de deformação que os geotêxteis podem apresentar. 


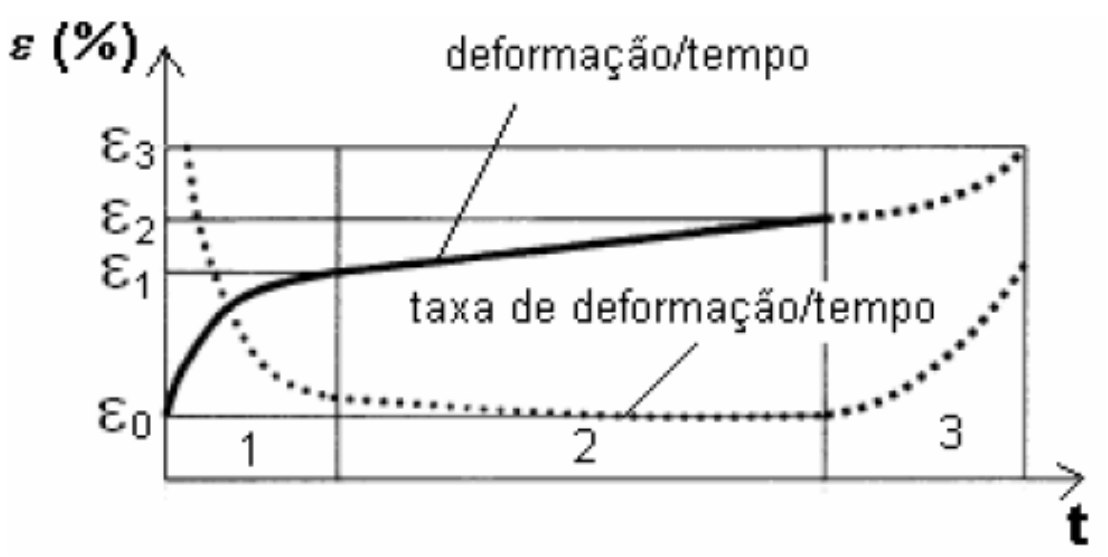

Figura 2-2 - Curva Típica de Fluência em geotêxteis. Fonte: REDDY \& BUTUL (1999).

Existem algumas maneiras de estudar o comportamento dos geotêxteis quanto à fluência, segundo KOERNER et al. (1988), são elas:

- Ensaios de laboratório: confinados e não confinados (convencional e acelerado);

- Projeções analíticas: necessitam de dados laboratoriais para o cálculo por meio de modelos empíricos, ou modelos reológicos;

Os ensaios de fluência apresentam uma concepção simples, no qual a finalidade é submeter um corpo de prova a um carregamento constante por certo período de tempo. O equipamento utilizado é composto por um sistema de ancoragem, um sistema de aplicação de carga e também por um método de acompanhamento das deformações, a análise das deformações é feita por um software de tratamento de imagens.

BARAS (2001) e COSTANZI (2003) estudaram o fenômeno de fluência em geotêxteis não tecidos. Eles utilizaram dois métodos de ensaios de fluência para estes estudos, o primeiro foi o ensaio convencional com duração de 42 dias, já o segundo método foi o ensaio acelerado proposto por THORNTON (1998), cujo tempo de ensaio é de apenas oito horas, este ensaio é o Stepped Isothermal Method (SIM).

FARRAG (1998) realizou ensaios acelerados por aumento de temperatura em geogrelhas de polietileno, neste estudo o autor utilizou um corpo de prova para cada aumento de temperatura, o que pode causar interferências nos resultados através da variabilidade do próprio material ensaiado. Pois cada corpo de prova apresentava uma deformação inicial diferente do outro, o que deveria ser corrigido por translações 
verticais feitas no eixo das deformações (eixo das ordenadas) no momento de criação da curva mestra.

Outro procedimento utilizado por FARRAG (1998) foi a utilização de fatores de mudança de tempo. Tais fatores auxiliavam nas translações horizontais (eixo das abcissas) fazendo com que as diferentes curvas obtidas nas respectivas temperaturas de ensaio se sobrepusessem e formassem a curva mestra extrapolada final. $\mathrm{O}$ autor se baseou na equação empírica de Williams, Landel, and Ferry (1955) com a utilização do fator de translação $\alpha_{\mathrm{T}}$, e propôs uma metodologia para estimar o valor de tal fator.

O fator $\alpha_{\mathrm{T}}$ apresenta dependência com a temperatura, isto é, o fator de translação apresenta um valor relacionado para cada temperatura escolhida no ensaio. A Figura 2-3 demonstra os resultados encontrados por FARRAG (1998) para diferentes temperaturas. $\mathrm{O}$ autor também demonstrou que o fator $\alpha_{\mathrm{T}}$ não apresenta variação significativa na mudança de seus resultados, quando o carregamento do corpo de prova é feito com diferentes cargas.

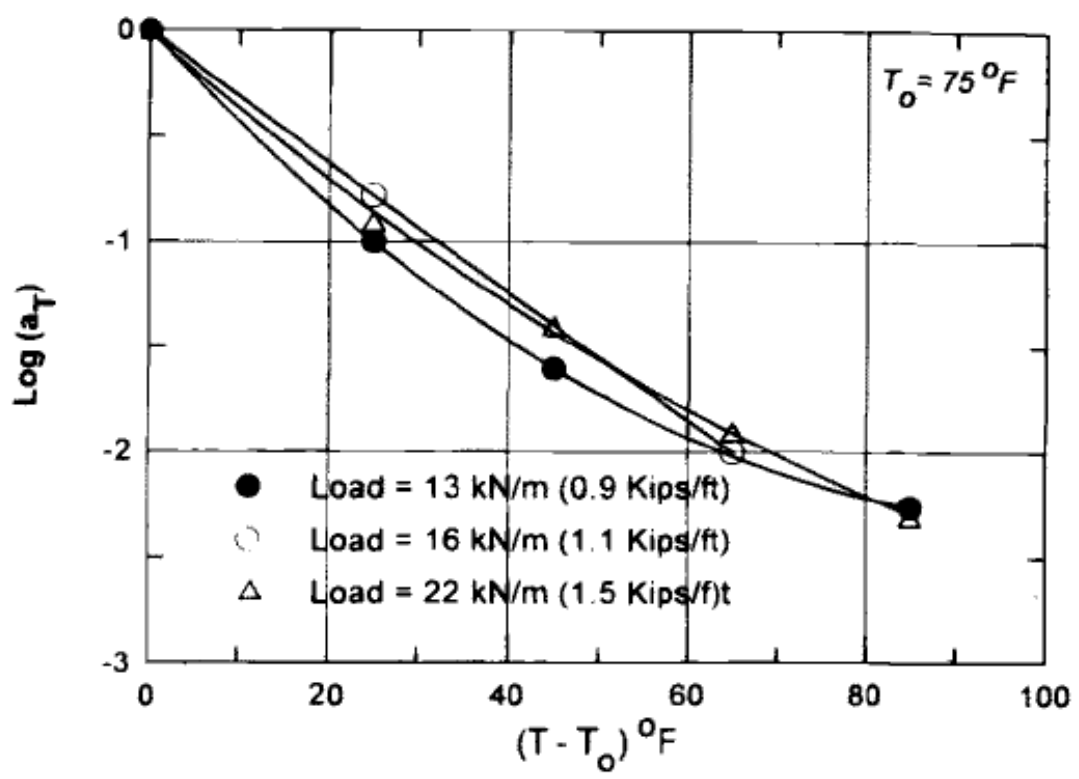

Figura 2-3 - Fator de translação versus temperatura. Fonte: FARRAG (1998).

O método SIM idealizado por THORNTON et al. (1998), busca minimizar os problemas de variabilidade do material, pois um único corpo de prova carregado com um peso constante, experimenta a variação da temperatura com o decorrer do tempo pré 
determinado para o ensaio. Tal ensaio baseia-se no princípio de Boltzmann, que admite o material com comportamento viscoelástico linear.

Para Boltzmann, a deformação por fluência é uma função da história de cargas aplicadas ao material, e cada carga aplicada é tratado como um evento independente. Sendo assim Boltzmann conclui que a soma de cada deformação, gerada por cada evento independente, resulta na deformação final do material. No método SIM a temperatura se apresenta como evento independente. A Figura 2-4 ilustra o comportamento de um material com esta característica.

O SIM apresenta carregamento constante de um corpo de prova, e tal solicitação é determinada através de uma porcentagem da tração máxima ao qual o material resiste, o corpo de prova fica exposto a incrementos de temperatura, sendo esses incrementos controlados pelo equipamento desenvolvido.

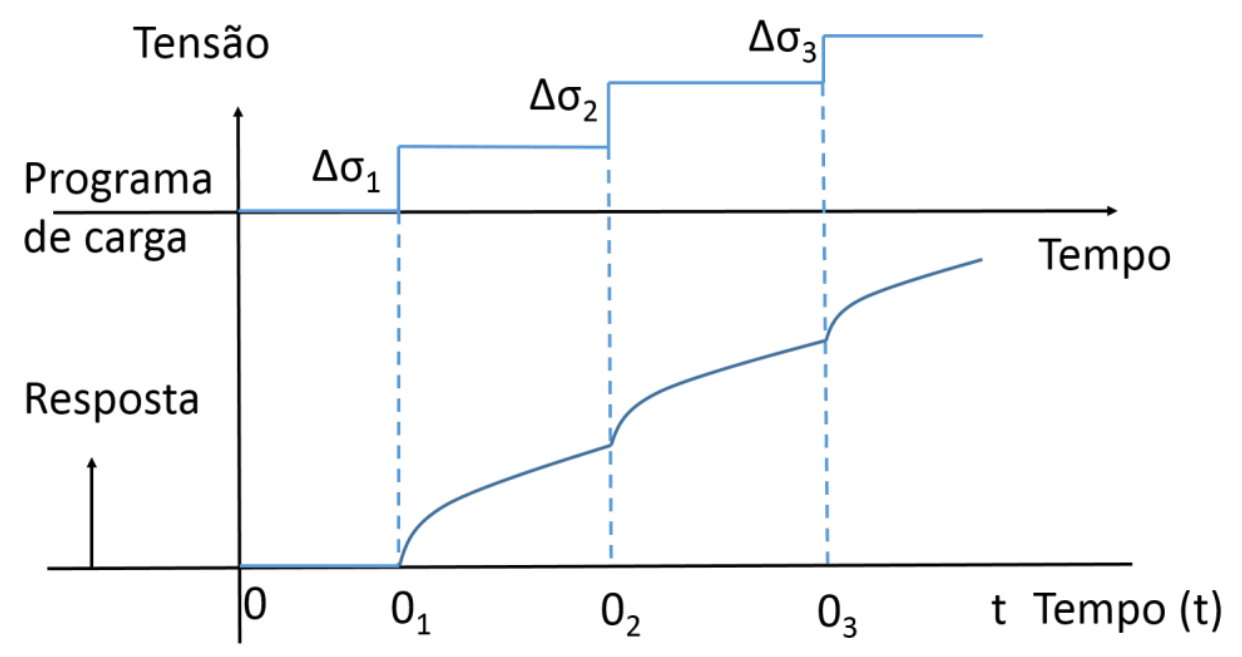

Figura 2-4 - Comportamento Viscoelástico Linear.

Nos estudos de THORNTON et al. (1998), são explicitados os passos para a obtenção da curva de fluência acelerada, as Figuras 2-5, 2-6, 2-7 e 2-8 e as exemplificações foram retiradas de BARAS (2001) e COSTANZI (2003). 
- $1^{\circ}$ passo: Plotar os dados de deformação por fluência e módulo de fluência em função do tempo, em escala linear, para identificar os tempos de início virtual dos estágios de temperatura, conforme Figura 2-5.

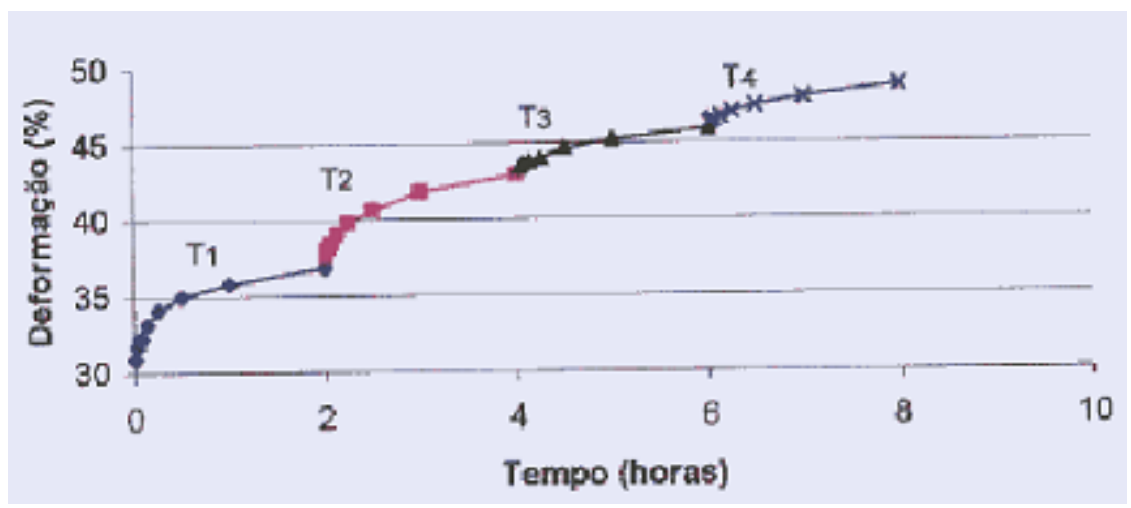

Figura 2-5 - $1^{\circ}$ passo. Fonte: BARAS (2001).

- $2^{\circ}$ passo: Usando os módulos de fluência e os parâmetros de interesse, devese plotar estes parâmetros em escala logarítmica para o eixo do tempo. Assim o primeiro ramo da curva de deformação ficara com formato linear, como pode ser visto na Figura 2-6.

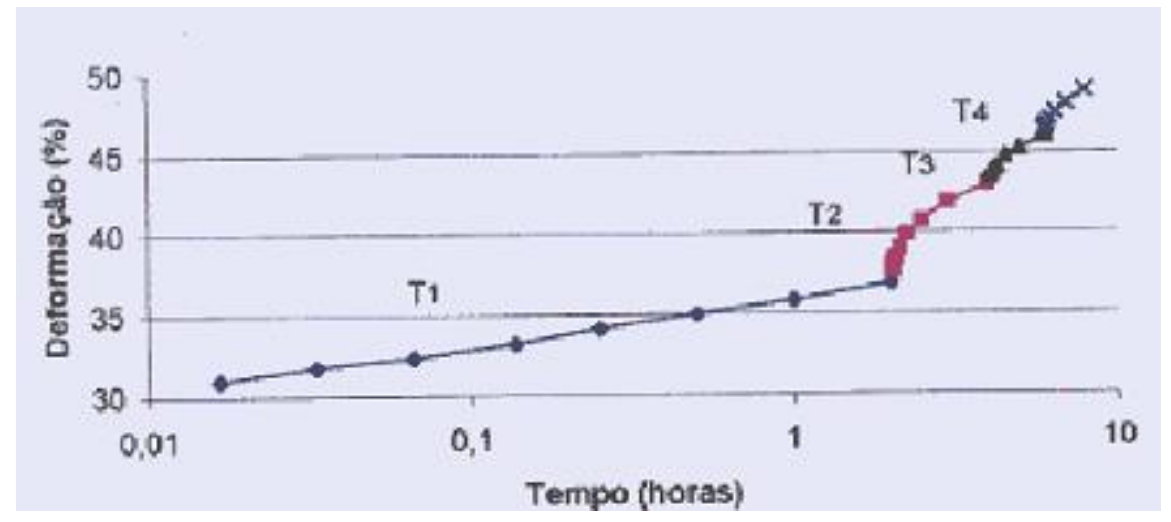

Figura 2-6 - ${ }^{\circ}$ passo. Fonte: BARAS (2001).

- $3^{\circ}$ passo: Mudar a escala de tempo para cada trecho do ensaio para plotá-los em escala logarítmica, de modo a obter seus tempos virtuais de início, como mostra a Figura 2-7. Isso ocorre quando a inclinação inicial do novo trecho é igual ao do final do trecho anterior. 


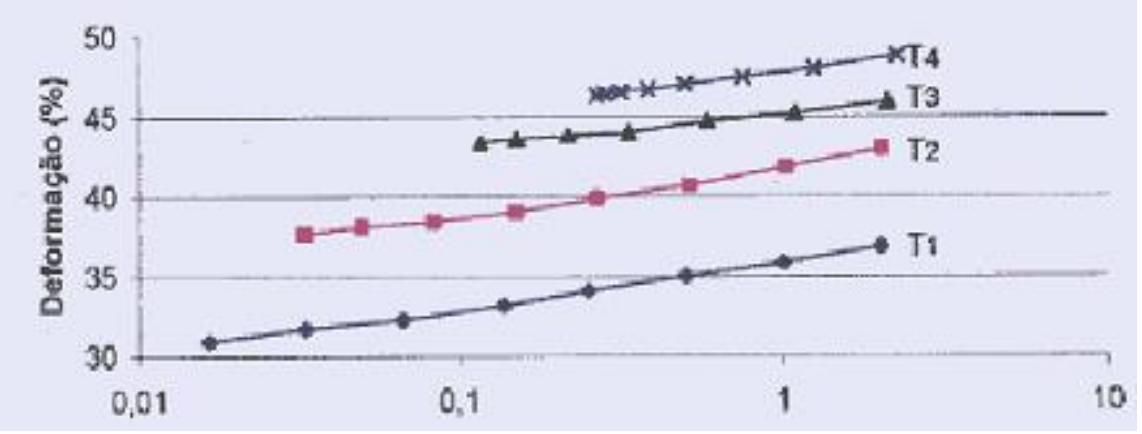

Figura 2-7 - $3^{\circ}$ passo. Fonte: BARAS (2001).

- $4^{\circ}$ passo: Remover os efeitos da expansão térmica através de translação vertical.

- $5^{\circ}$ passo: Através de translações horizontais obter a exata justaposição dos trechos e formar a curva de fluência acelerada, conforme a Figura 4-8. As translações não podem afetar as curvas obtidas anteriormente.

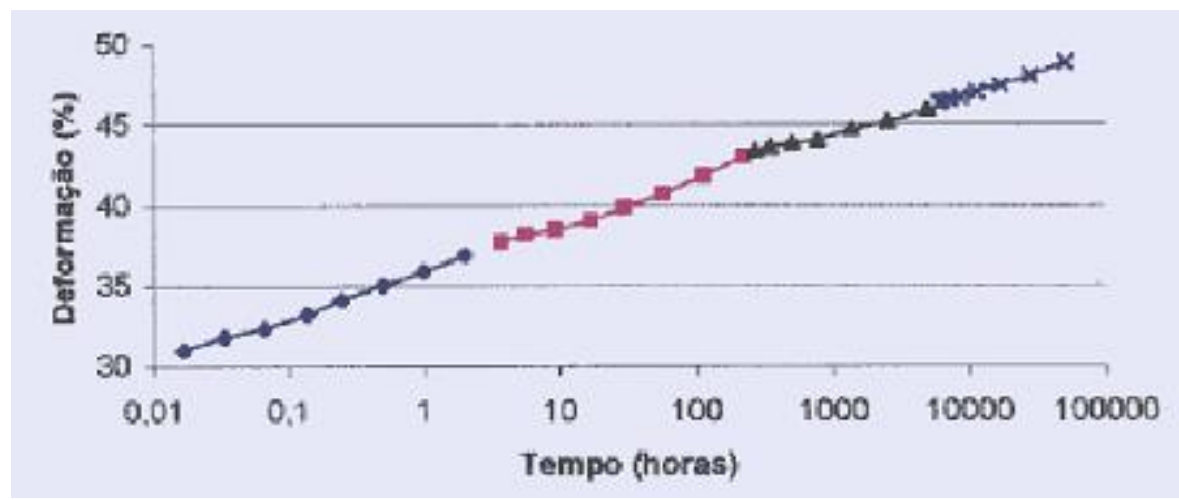

Figura 2-8 $-4^{\circ}$ e $5^{\circ}$ passos. Fonte: BARAS (2001).

BARAS (2001) ensaiou dois tipos de geotêxteis não tecidos, suas características diferiram quanto à matéria prima e o tipo de fibras. Os dois geotêxteis apresentavam estrutura agulhada, mas um deles era composto por fibras cortadas e matéria prima de polipropileno e o outro tipo era de fibra de filamentos contínuos e matéria prima de poliéster.

Os carregamentos aplicados nos corpos de prova foram da ordem de 10\%, 20\%, $40 \%$ e $60 \%$ do carregamento de tração máxima que causa a ruptura do geotêxtil. Foram ensaiados geotêxteis com a massa por unidade de área de $300 \mathrm{~g} / \mathrm{m}^{2}$. Para cada tipo de 
material foram feitos um ensaio convencional por carregamento e também um ensaio acelerado para cada um dos quatro diferentes carregamentos. As faixas de temperatura utilizadas pelo autor foram de: temperatura ambiente, $40^{\circ} \mathrm{C}, 50^{\circ} \mathrm{C}$ e $60^{\circ} \mathrm{C}$.

As Figuras 2-9 e 2-10 abaixo demonstram os resultados obtidos por BARAS (2001) nos ensaios convencionais.

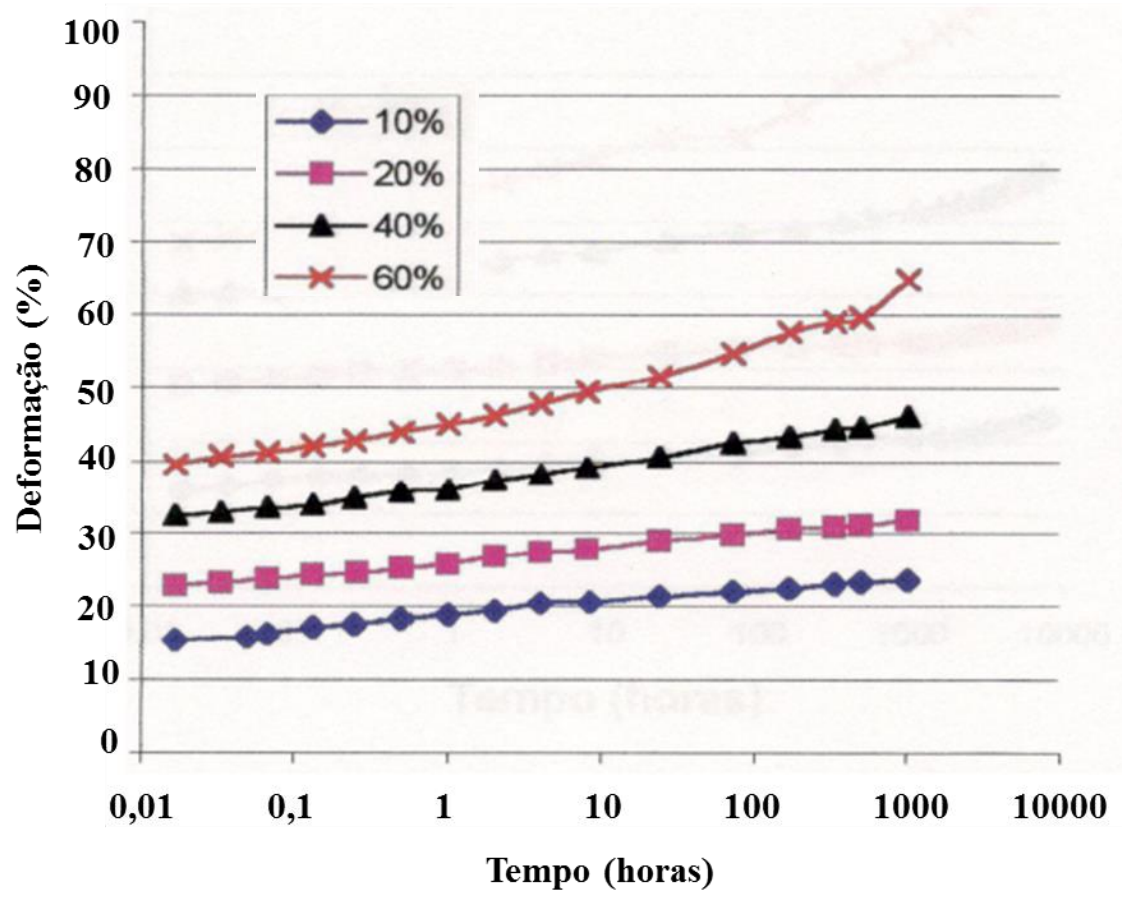

Figura 2-9 - Ensaio convencional, geotêxtil de polipropileno. Fonte: BARAS (2001).

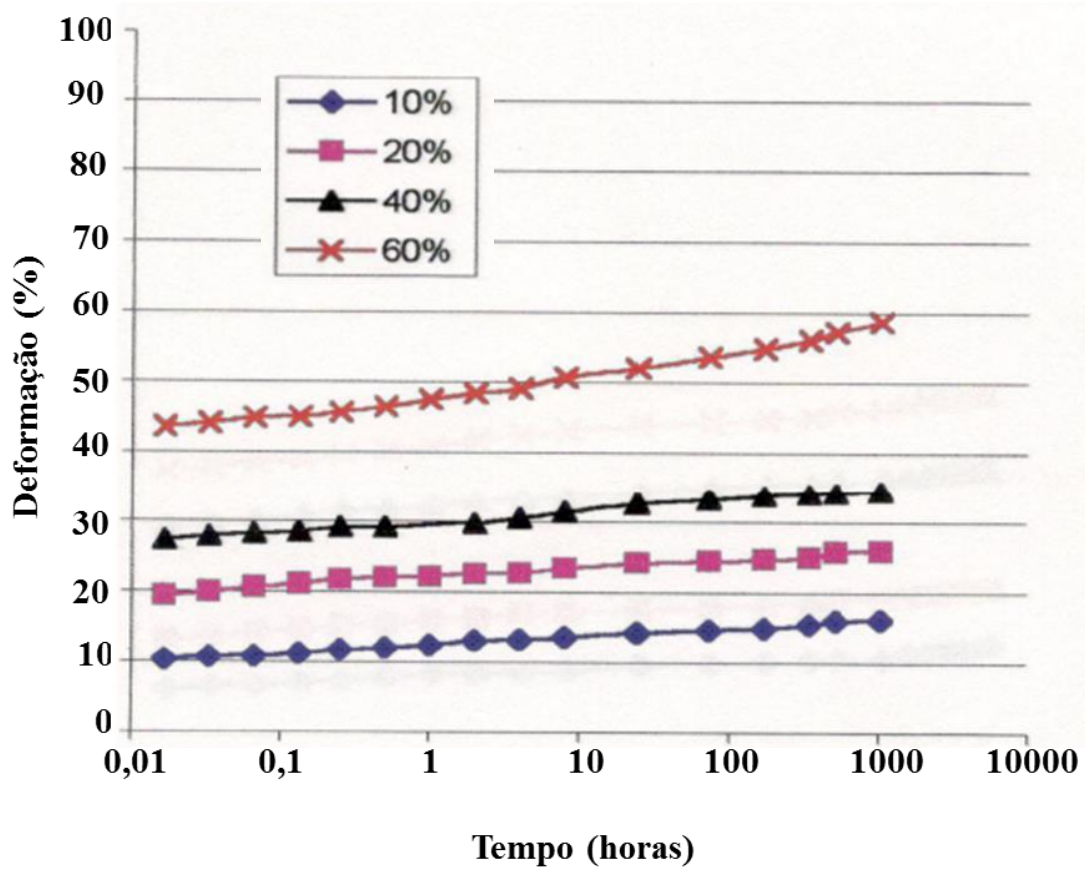


Figura 2-10 - Ensaio convencional, geotêxtil de poliéster. Fonte: BARAS (2001).

As Figuras 2-11 e 2-12 abaixo demonstram os resultados obtidos por BARAS (2001) nos ensaios acelerados para os dois diferentes tipos de geotêxteis.

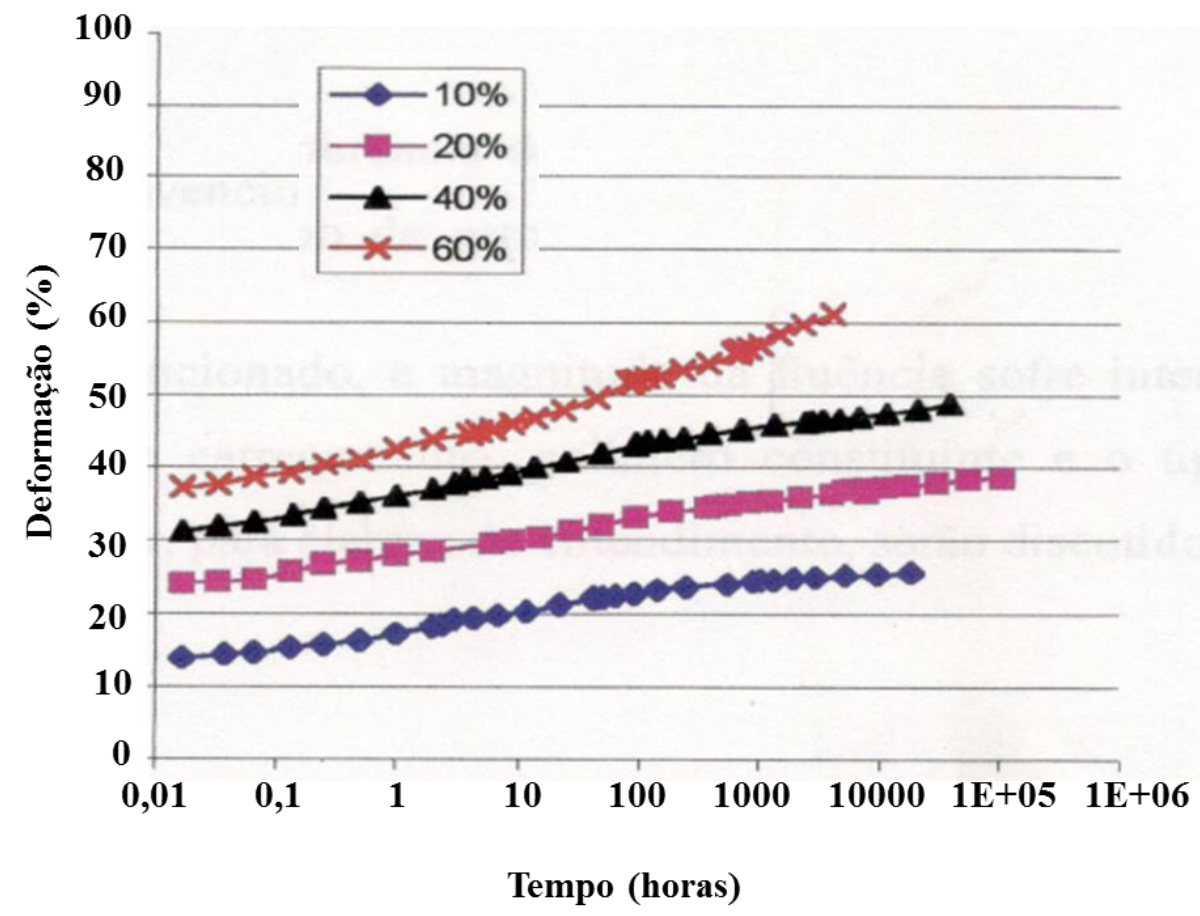

Figura 2-11 - Ensaio acelerado, geotêxtil de polipropileno. Fonte: BARAS (2001).

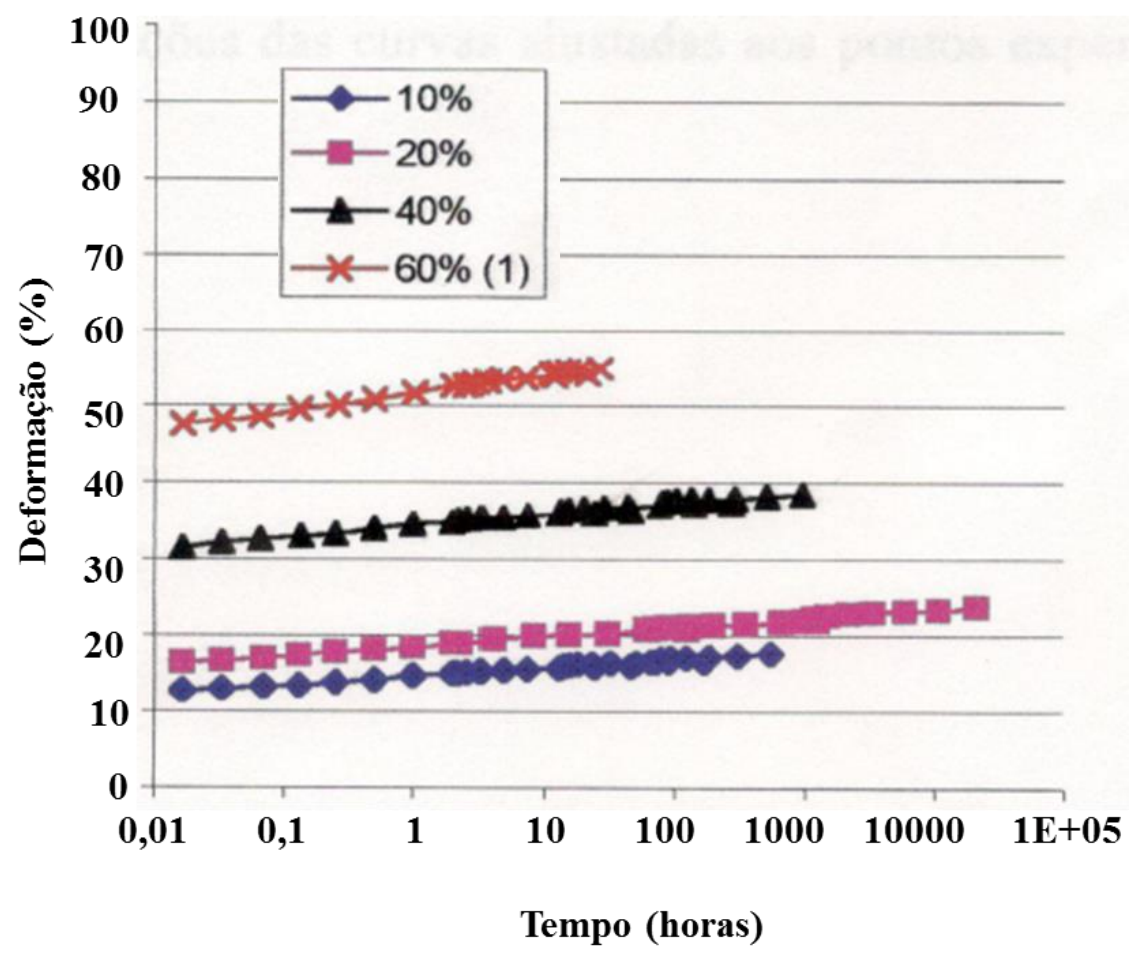

Figura 2-12 - Ensaio acelerado, geotêxtil de poliéster. Fonte: BARAS (2001). 
As curvas de fluência, tanto do ensaio acelerado como do ensaio convencional, apresentaram boa concordância para ambos os tipos de geotêxteis. BARAS (2001) fez uma comparação entre os coeficientes angulares das retas obtidas e os níveis de carregamento ao qual o geotêxtil foi solicitado, ele concluiu que quanto maior era o carregamento ao qual o material era submetido, o coeficiente angular resultante era menor, isto é, quanto maior a carga, mais intenso era a fluência no geotêxtil. Outra conclusão obtida foi a de que o geotêxtil de poliéster apresentava um coeficiente de fluência menor que os encontrados para o material de polipropileno.

Já COSTANZI (2003) estudou dois tipos de geotêxteis não tecidos, as características dos materiais eram parecidas com as estudas por BARAS (2001). Os dois geotêxteis apresentavam estrutura agulhada, um era composto por fibras cortadas e matéria prima de polipropileno e o outro tipo era de fibra curta e matéria prima de poliéster. Os dois geotêxteis possuíam massa por unidade de área média de $300 \mathrm{~g} / \mathrm{m}^{2}$.

Os carregamentos aplicados nos corpos de prova foram da mesma ordem dos utilizados no estudo realizado por BARAS (2001). Entretanto, a quantidade de ensaios foi maior, perfazendo um total de dezesseis ensaios para cada tipo de geotêxtil. Do total de ensaios para cada geotêxtil, quatro deles eram ensaios convencionais (um para cada nível de carregamento) e doze eram ensaios acelerados pelo método SIM (três para cada nível de carregamento).

Os resultados obtidos para o geotêxtil fabricado com matéria prima de polipropileno podem ser vistos na Figura 2-13. COSTANZI (2003) encontrou curvas de fluência que variavam com alcance entre 13 a 1959 anos. Esta variação das curvas foi creditada a alta variabilidade das propriedades mecânicas do material. As faixas de temperatura utilizadas pelo autor foram as mesmas utilizadas por BARAS (2001): temperatura ambiente, $40^{\circ} \mathrm{C}, 50^{\circ} \mathrm{C}$ e $60^{\circ} \mathrm{C}$. 


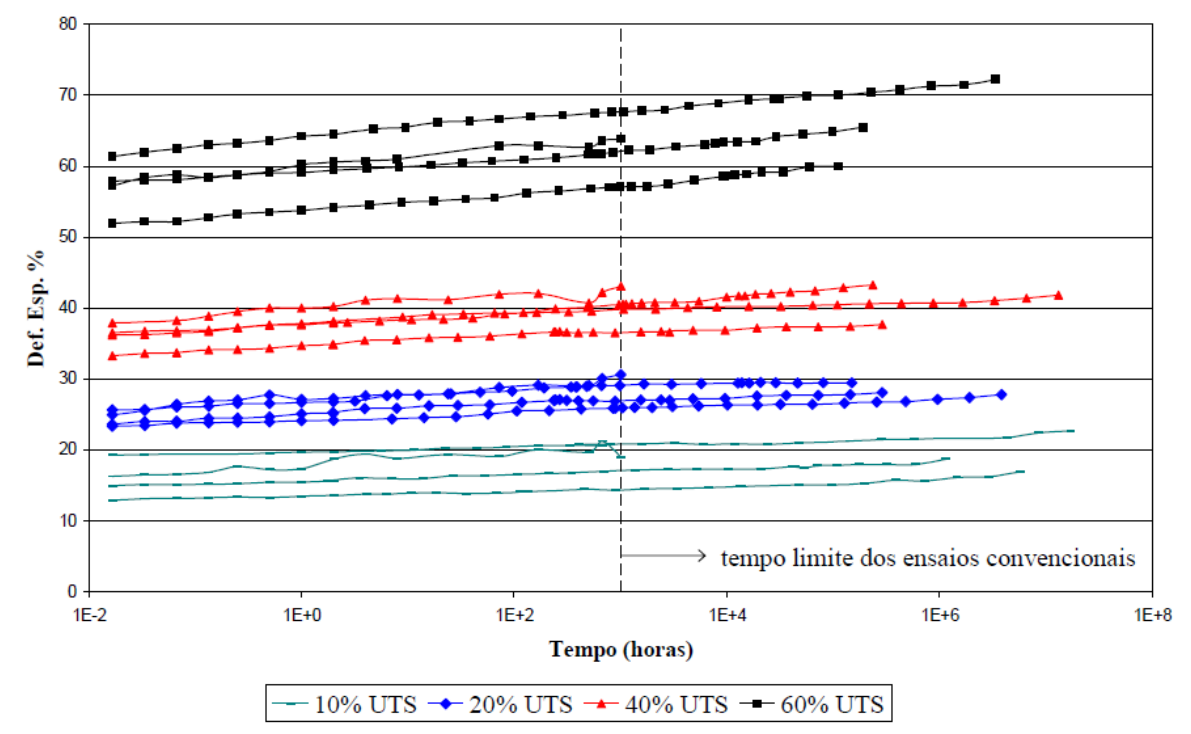

Figura 2-13 - Fluência geotêxtil de polipropileno. Fonte: COSTANZI (2003).

Já a Figura 2-14 demonstra os resultados obtidos para a fluência no material do tipo poliéster. $\mathrm{O}$ alcance das curvas apresentou uma maior variação de suas extensões se comparadas com as encontradas no material constituído de polipropileno. Os tempos encontrados perfazem uma faixa de 4 a 3649 anos. Mais uma vez o autor creditou tal oscilação temporal a alta variabilidade inerente ao material.

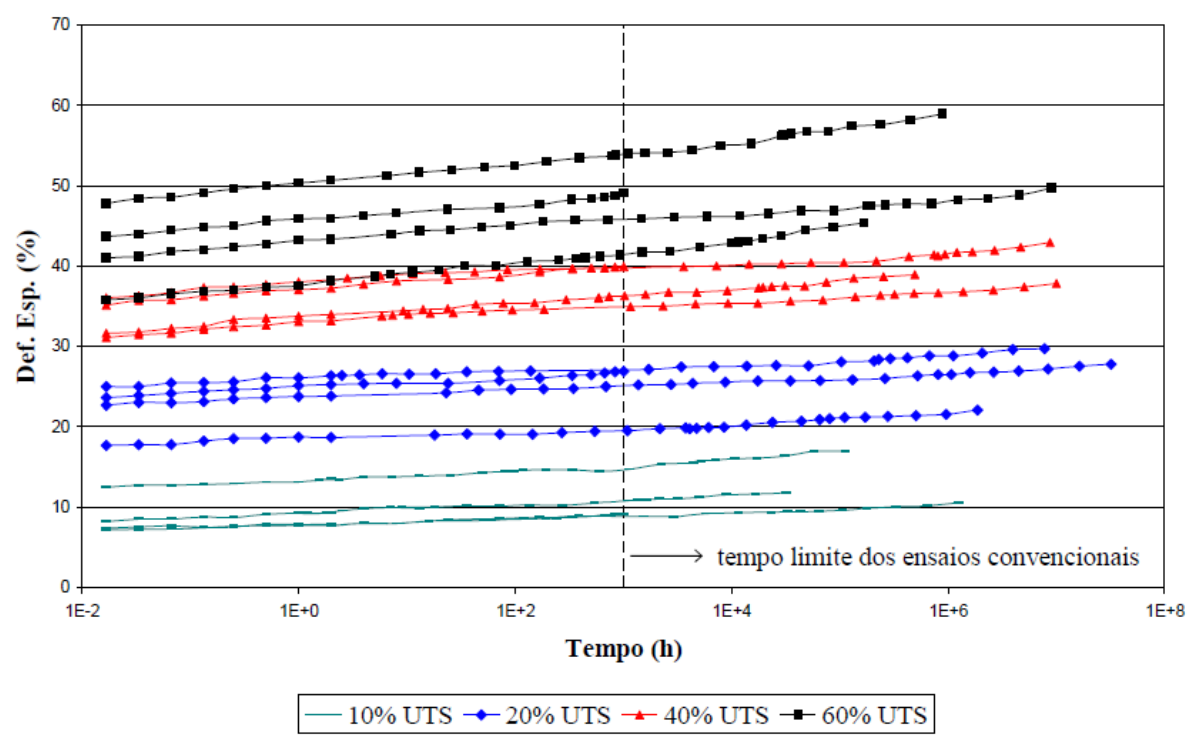

Figura 2-14 - Fluência geotêxtil de poliéster. Fonte: COSTANZI (2003). 
Observou-se também que os coeficientes angulares das curvas mestras tendem a crescer com o aumento do carregamento ao qual o corpo de prova foi submetido, o que também causou uma maior deformação inicial.

Além dos ensaios convencionais e acelerados feito pelo autor agora citado, COSTANZI (2003) também ensaiou os dois materiais até sua ruptura por fluência. O equipamento utilizado para o ensaio SIM, auxiliou no encurtamento do tempo de ensaio por ruptura, pois o aumento da temperatura e o aumento dos carregamentos aos quais os corpos de prova foram submetidos fizeram com que o material se rompesse através da fluência em tempos muito mais baixos que os convencionais.

Os carregamentos utilizados para este tipo de ensaio por ruptura foram de $65 \%$, $70 \%, 75 \%, 80 \%, 85 \%$ e $90 \%$ do carregamento de tração máxima que causa a ruptura do geotêxtil. Os tempos de ruptura variaram de 0,02 a 34,25 horas de ensaio. A partir dos resultados encontrados, pode-se traçar uma curva de ruptura por fluência, a Figura 2-15 detalha a curva encontrada para o material de polipropileno, já a Figura 2-16 demonstra o resultado obtido para o geotêxtil de poliéster.

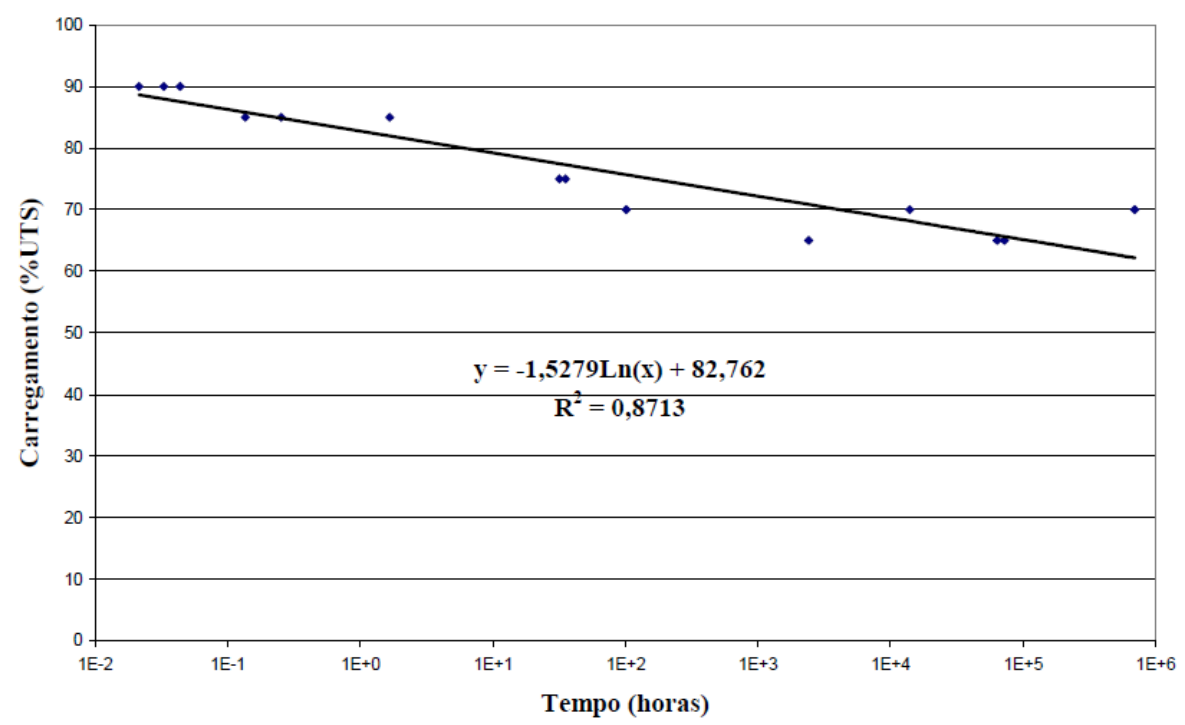

Figura 2-15 - Ruptura por fluência, polipropileno. Fonte: COSTANZI (2003). 


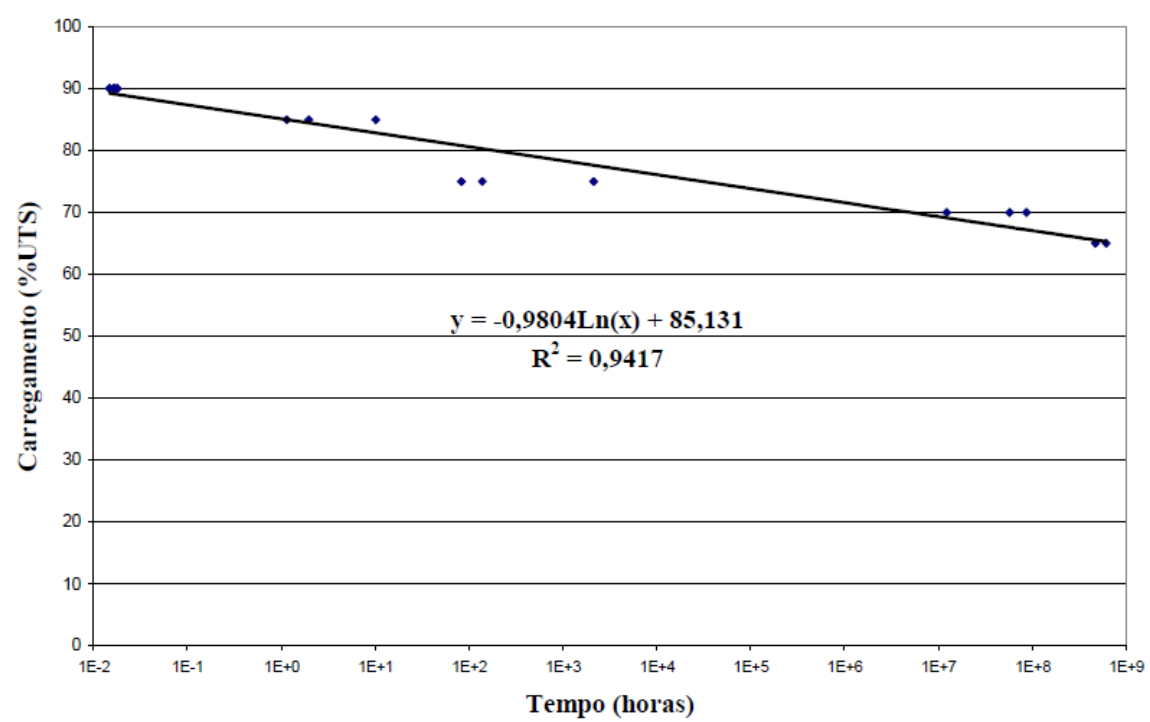

Figura 2-16 - Ruptura por fluência, poliéster. Fonte: COSTANZI (2003).

Os tempos de ruptura encontrados nos ensaios feitos para o geotêxtil de poliéster variaram de 0,02 a 49,83 horas. COSTANZI (2003) conclui que os dois resultados encontrados mostraram-se coerentes, e apesar da variabilidade do material, os coeficientes de correlação encontrados foram satisfatórios.

Com os resultados anteriores obtidos pelo autor, foi possível calcular os respectivos fatores de redução de ruptura por fluência para os dois diferentes materiais. COSTANZI (2003) se baseou na Equação 2.2 para encontrar tais valores de redução.

$$
T_{a}=\frac{T_{\max }}{F R_{F L}}
$$

Onde:

$F R_{F L}$ é o fator de redução parcial,

$\mathrm{T}_{\mathrm{a}}$ é a tensão admissível para certo período,

$\mathrm{T}_{\max }$ é a resistência a tração na ruptura.

A Tabela 2-2 abaixo determina os valores de acordo com o tempo de projeto. 
Tabela 2-1 - Fatores de redução devido a fluência. Fonte: COSTANZI (2003).

\begin{tabular}{c|c|c}
\hline \multirow{2}{*}{$\begin{array}{c}\text { Tempo de Vida } \\
\text { (Anos) }\end{array}$} & \multicolumn{2}{|c}{ Fatores de Redução } \\
\cline { 2 - 3 } & Polipropileno & Poliéster \\
\hline 1 & 1,5 & 1,3 \\
10 & 1,5 & 1,4 \\
70 & 1,6 & 1,4 \\
120 & 1,6 & 1,4 \\
\hline
\end{tabular}

Os valores de tais fatores de redução encontrados se apresentam dentro do intervalo ou mesmo abaixo dos recomendados pela literatura para os dois tipos de materiais ensaiados no estudo.

ZORNBERG et al. (2004) realizou ensaios acelerados do tipo SIM para caracterizar a curva de falha por fluência de um geotêxtil tecido de polipropileno. Para o autor o fator de redução por fluência é baseado através da curva de ruptura por fluência do geotêxtil. Já a curva de falha proposta pelo autor é definida como o ponto do gráfico onde o comportamento da curva deixa de ser linear, isto demonstra a falha do material e não a ruptura do geossintético. A Figura 2-17 demonstra este ponto.

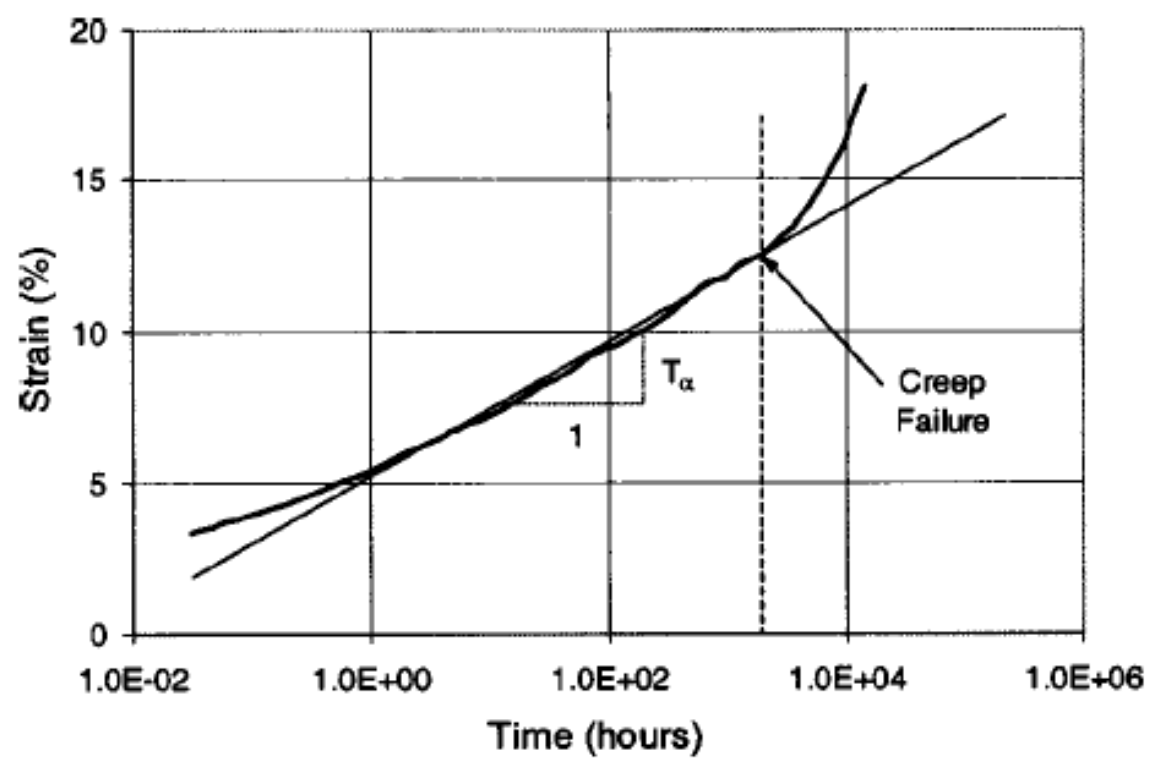

Figura 2-17 - Definição de falha por fluência. Fonte: Zornberg (2004). 


\subsubsection{Fluência confinada em geotêxteis}

Para FRANÇA (2012), o comportamento da fluência apresenta relação com as tensões confinantes ao qual o geossintético está submetido no meio. Os ensaios confinados são realizados em câmaras próprias onde o geotêxtil se apresenta confinado pelo solo.

COSTA (2004) desenvolveu um equipamento que representasse as deformações ocorridas em um elemento de solo reforçado (muro reforçado com geotêxtil). A autora simulou a transferência de carga para o solo reforçado, ocorrendo assim à deformação tanto do solo como do geotêxtil. A Figura 2-18 expõe o equipamento desenvolvido.

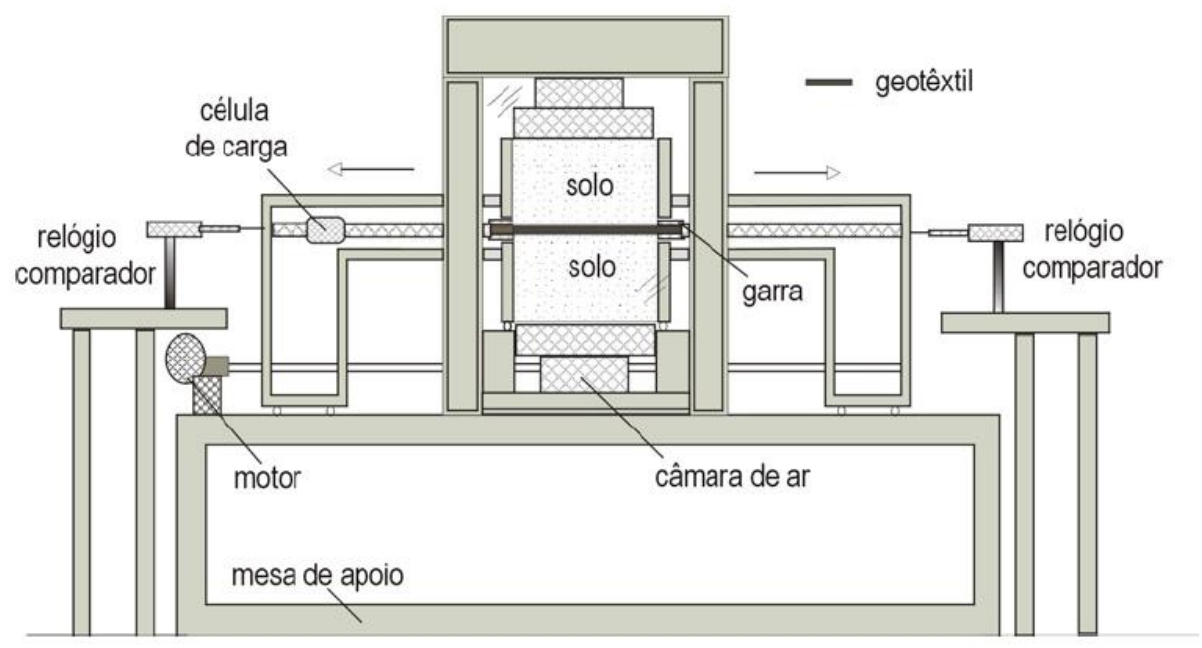

Figura 2-18 - Equipamento desenvolvido por COSTA (2004).

COSTA (2004) realizou ensaios confinados em areia, através do equipamento demonstrado pela Figura 2-18. A autora encontrou resultados de fluência confinada ao longo do tempo semelhante aos resultados encontrados em ensaios de fluência convencional. A Figura 2-19 exemplifica um dos resultados encontrados por COSTA (2004), é feito uma comparação entre o modelo confinado e as deformações de fluência não confinada. O carregamento utilizado neste resultado é de $80 \%$ do carregamento máximo do material. 


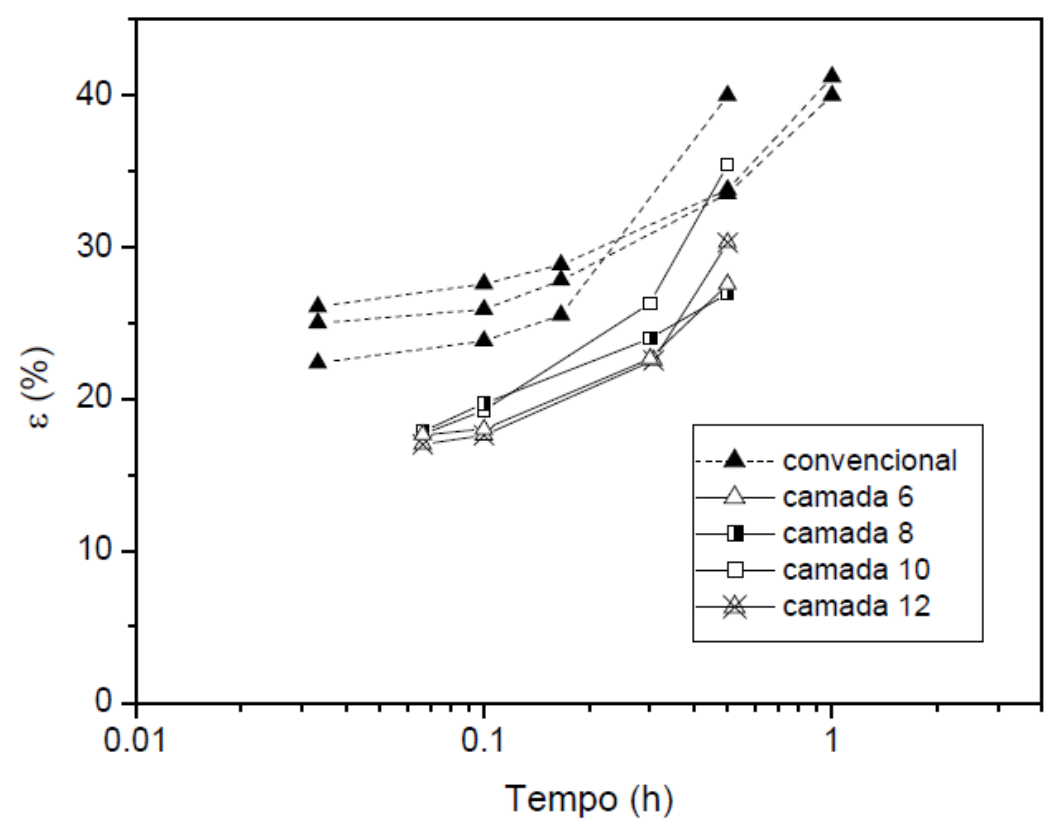

Figura 2-19 - Comparação entre fluência confinada e não confinada. Fonte: COSTA (2004).

Mesmo com o desenvolvimento de ensaios confinados, para o melhor entendimento da fluência do material quando em interação com o solo, o ensaio de fluência ainda é um fenômeno dependente de longos tempos.

FRANÇA (2012) desenvolveu um equipamento que agregava o confinamento do geotêxtil com o solo e o aumento da temperatura do meio, criando um novo ensaio de fluência por confinamento acelerado. $\mathrm{O}$ autor realizou ensaios confinados, ensaios acelerados e também ensaios confinados e acelerados, tudo isto para entender melhor como a fluência, no geotêxtil, se comporta em diferentes modelos.

A Figura 2-20 exemplifica o equipamento desenvolvido para o ensaio confinado acelerado. Tal aparelho possui elementos de aplicação de carga, câmara para o confinamento do geossintético no solo, resistências que auxiliam no aumento de temperatura e aquisição dos dados de deformação do corpo de prova.

FRANÇA et al. (2011) realizou um ensaio, neste equipamento, com um geotêxtil não tecido de matéria prima poliéster com massa por unidade de área de $313 \mathrm{~g} / \mathrm{m}^{2}$, e o meio de confinamento era composto por uma areia seca mal graduada (SP). Para fins comparativos foi realizado um ensaio convencional de fluência não confinado, um ensaio confinado na temperatura ambiente e um ensaio confinado acelerado na temperatura de $49^{\circ}$. 
A partir da Figura 2-21 abaixo, os autores concluíram que a fluência do geotêxtil não tecido de poliéster apresenta dependência com as tensões confinantes do solo. Houve uma redução de aproximadamente $50 \%$ das deformações por fluência se comparado ao ensaio convencional não confinado. Lembrando que neste modelo de ensaio o solo atua passivamente, inibindo a deformação por fluência.

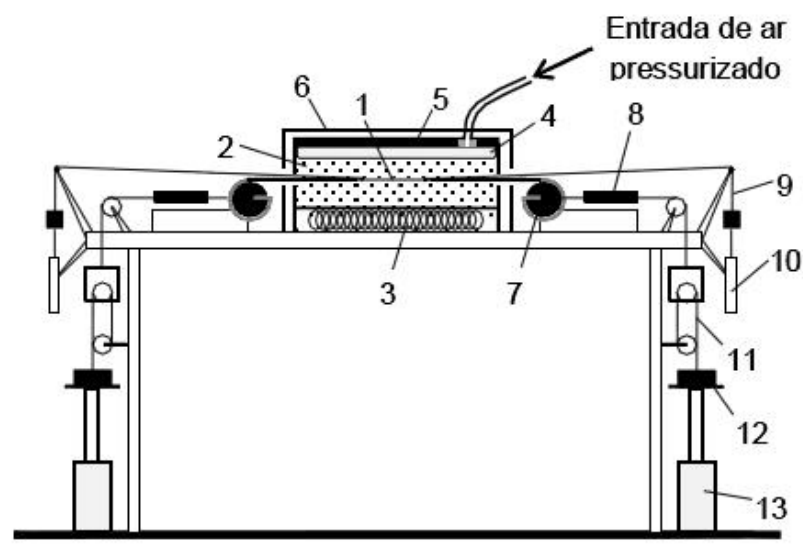

1 - Corpo de prova

2 - Compartimento superior da câmara de ensaio (meio confinante e corpo de prova)

3 - Compartimento inferior da câmara de ensaio (sistema de aquecimento)

4 - Bolsa de ar pressurizado

5 - Tampa da câmara de ensaio

6 - Cobertura em poliestireno expandido

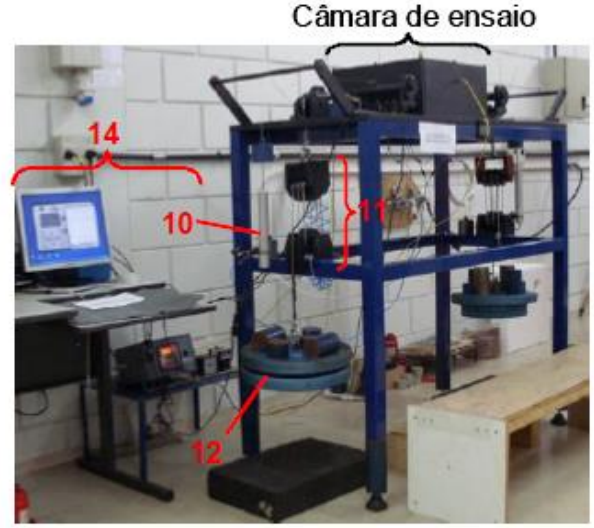

7 - Garra do tipo rolete

8 - Célula de carga

9 - Fio de aço inextensível

10 - Transdutor de deslocamento

11 - Conjunto de polias

12 - Peso livre

13 - Macaco hidráulico

14 - Sistema de aquisição de dados

Figura 2-20 - Equipamento desenvolvido por FRANÇA (2012).

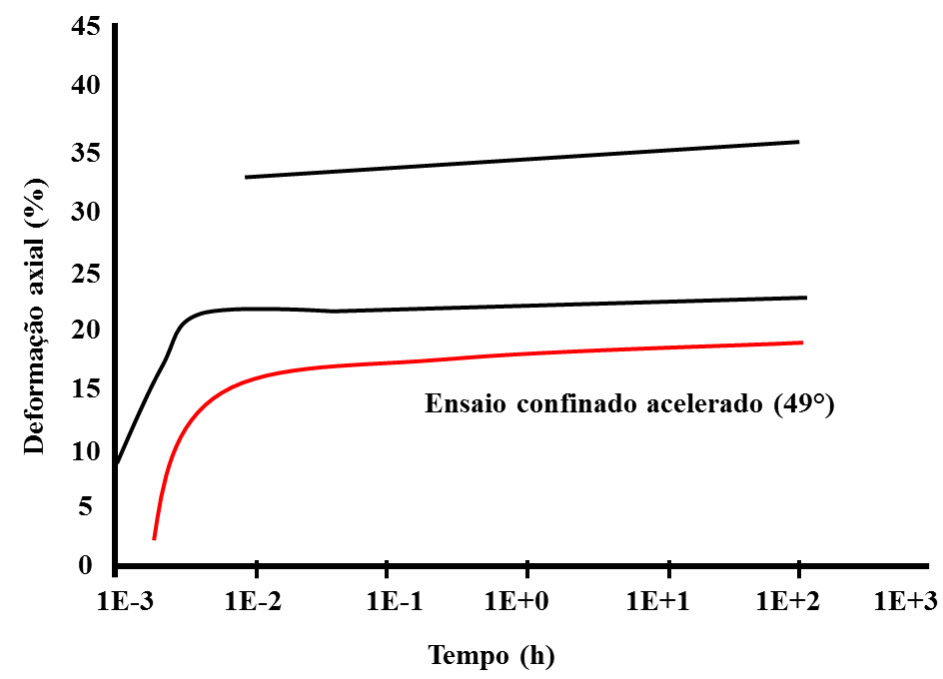

Figura 2-21 - Ensaio geotêxtil poliéster, FRANÇA et. al. (2011). 
As pesquisas de COSTA (2004) e FRANÇA (2012) estudaram o comportamento dos elementos frente ao confinamento em solo. Os autores divergiram quanto aos resultados de deformação por fluência do geotêxtil. Para COSTA (2004) a fluência confinada apresenta valores próximos dos resultados encontrados em ensaios de fluência não confinada, em contra partida FRANÇA (2012) encontrou resultados que divergiam em uma redução de até $50 \%$ dos comparados com os ensaios convencionais não confinados.

Esta diferença entre os resultados encontrados pelos dois autores pode ser explicada pelo modelo de carregamento utilizado nos equipamentos desenvolvidos para os ensaios. No estudo de COSTA (2004), o carregamento era feito por um mecanismo que distribuía os esforços para o solo confinado e, por conseguinte a transferência de carga para o geotêxtil se dava por meio da configuração solo-reforço. Já no estudo de FRANÇA (2012), o geotêxtil era diretamente solicitado por meio de um mecanismo que gerava um carregamento igualitário nas duas extremidades da amostra através de um sistema de polias e pesos.

Outros equipamentos desenvolvidos para avaliar a fluência confinada em geotêxteis podem ser vistos em McGOWN et. al. (1982), WU \& HELWANY (1996), HELWANY $\&$ SHIN (1998), entre outros.

\subsection{MODELOS DE DEFORMAÇÃO}

Em engenharia, prever o comportamento dos materiais torna-se um trabalho muito complexo, tendo em vista que, alguns materiais podem demonstrar deformação completamente elástica ou temporária, outros apresentam resposta totalmente viscosa ou permanente, e, ainda, existe uma gama de materiais que apresentam características de viscoelasticidade.

Estudos desenvolvidos por autores como McGown et al (1982) e Leshchinsky et al. (1997) demonstraram que os polímeros constituintes de materiais geossintéticos estão susceptíveis até certo ponto ao fenômeno de fluência, isto é, são materiais viscoelásticos e apresentam resposta simultaneamente elástica e viscosa. O comportamento mecânico do "creep" é influenciado por diferentes fatores, e tendem a ser mais ou menos efetivo de acordo com o tipo de polímero, sendo o comportamento de tensão versus deformação 
dos geossintéticos uma função relacionada à taxa de deformação e a temperatura do ambiente (Thornton et al. 1998).

A característica viscoelástica do geotêxtil influência no desempenho estrutural do reforço, sendo creditada à deformação por fluência (e, ou ruptura por fluência), uma maior preocupação quando o desempenho estudado é o de longo prazo em estruturas permanentes.

Como o comportamento unidimensional de um material viscoelástico pode ser aproximado à um conjunto constituído por materiais elásticos e materiais viscosos, podemos primeiramente definir suas características individuais segundo Flügge (1967).

Os elementos com características elásticas podem ser facilmente associados a elementos de mola, isto é, quando aplica-se uma força concentrada $\mathbf{F}$ em sua extremidade (Figura 2-22), ocorre uma deformação e consequentemente um aumento de seu comprimento. Com a retirada deste esforço, a mola volta ao seu comprimento original.

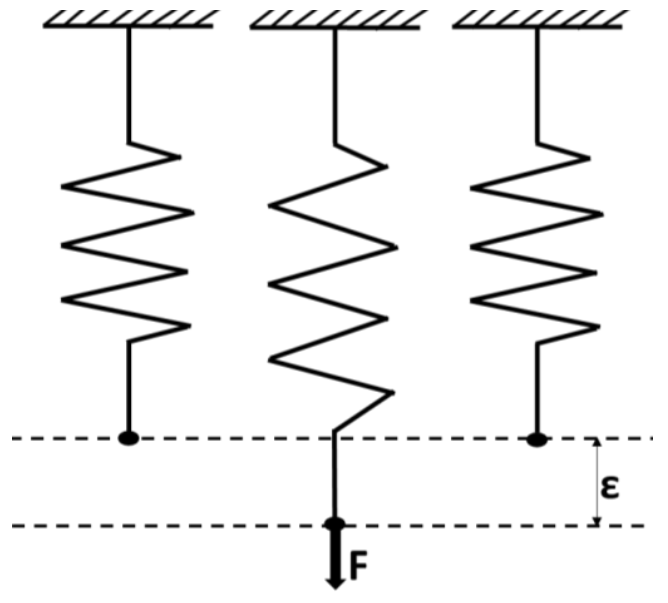

Figura 2-22 - Elemento com característica elástica.

Desta maneira um material com característica elástica não apresenta deformação residual e, pode-se associa-lo a Lei de Hook com comportamento elástico linear. A Equação 2.3 define a Lei de Hook.

$$
\sigma=E . \varepsilon
$$

Onde: $\sigma=$ Tensão axial do sistema;

$\mathrm{E}=$ Módulo de Young do material; 


$$
\varepsilon=\text { Deformação. }
$$

Em contrapartida, materiais com comportamento viscoso são comumente associados à característica de um pistão (Figura 2-23), isto é, ao aplicar uma força $\mathbf{F}$ em sua extremidade, o material é forçado a escoar, e a viscosidade deste, é a resistência que o material oferece ao escoamento. Quanto maior é a intensidade da força $\mathbf{F}$ maior será a deformação do pistão, e quando o carregamento é retirado, o escoamento cessa.

De uma forma simples, esta relação de força $x$ deslocamento pode ser interpretado através de um modelo conhecido como “modelo viscoso de Newton” (Equação 2.4).

$$
\sigma=\eta \cdot \frac{d \varepsilon}{d t}
$$

Onde:

$\sigma=$ Tensão aplicada;

$\eta=$ Viscosidade do material;

$\varepsilon=$ Deformação;

$\mathrm{t}=$ Tempo.

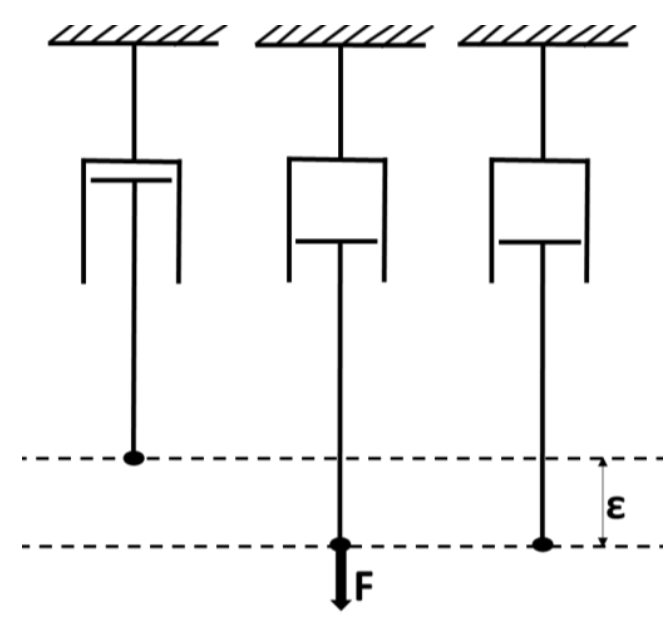

Figura 2-23 - Elemento com característica viscosa.

Existem inúmeras formas de modelar um comportamento viscoelástico, o ponto principal desta tarefa está na escolha de uma forma adequada de combinação entre os componentes elástico e viscoso (sistema mola-pistão), para que represente o melhor sistema possível para prever adequadamente o comportamento do material em função do tempo. De modo geral, até mesmo o modelo mais complexo de um material pode ser obtido através de combinações de elementos simples. 
Quando a tensão aplicada no elemento viscoelástico deixar de existir, o material tende a retornar as suas dimensões originais. A tensão elástica remanescente na amostra é que ditará a magnitude desta recuperação. Amostras puramente elásticas apresentam recuperação perfeita, porém amostras puramente viscosas são incapazes de demonstrar alguma recuperação. A Figura 2-24 ilustra o comportamento da deformação em elementos elásticos e a Figura 2-25 em materiais do tipo viscoso.

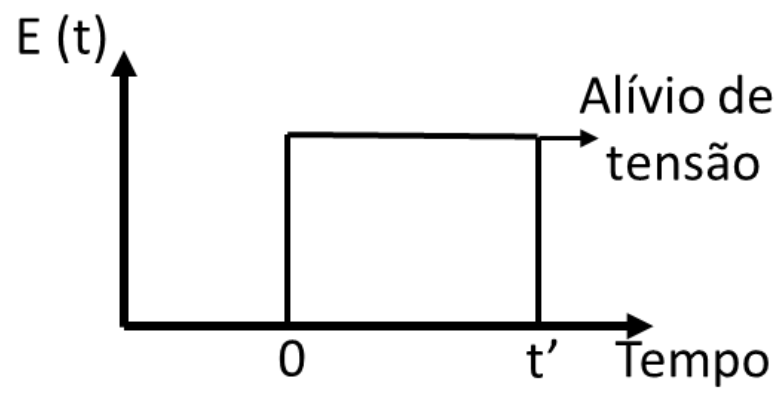

Figura 2-24 - Deformação elástica.

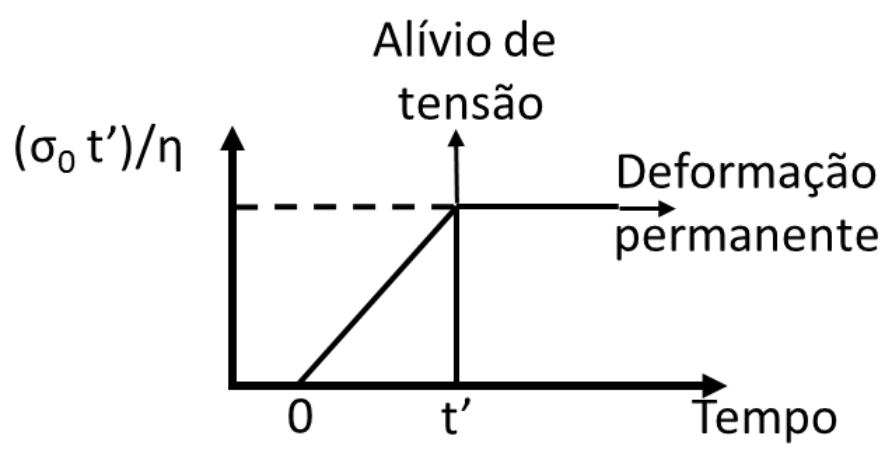

Figura 2-25 - Deformação viscosa.

\subsubsection{Modelos reológicos}

Foram propostos vários modelos mecânicos para descrever materiais com comportamento viscoelástico linear, a combinação entra mola e pistão pode ocorrer de forma paralela ou em série.

O modelo de Maxwell combina em serie o sistema mola pistão, este modelo auxilia no estudo de relaxação de tensão em que a deformação é constante de alguns materiais. 
Este modelo não é indicado para estudo de fluência, onde a tensão é constante. A Figura 2-26 exemplifica este modelo.

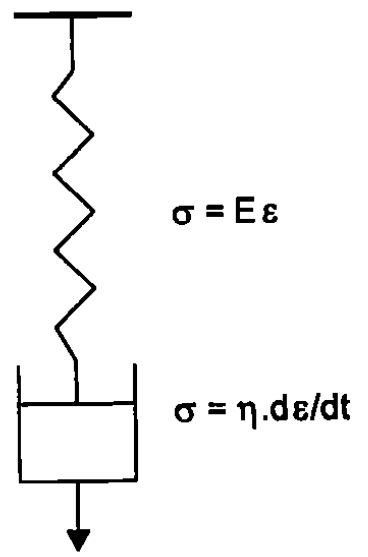

Figura 2-26 - Modelo de Maxwell.

YEO, S. S. (2007) cita um dos exemplos mais simples de modelo mecânico, tal exemplar trata-se de uma combinação em paralelo de mola-pistão, e é denominado sistema de Kelvin (ou Voigt). Esta combinação demonstra o comportamento elástico e o comportamento viscoso sofrido pelo material, e torna-se útil para descrever o experimento de fluência em que a tensão é constante. A Figura 2-27 ilustra a composição do modelo.

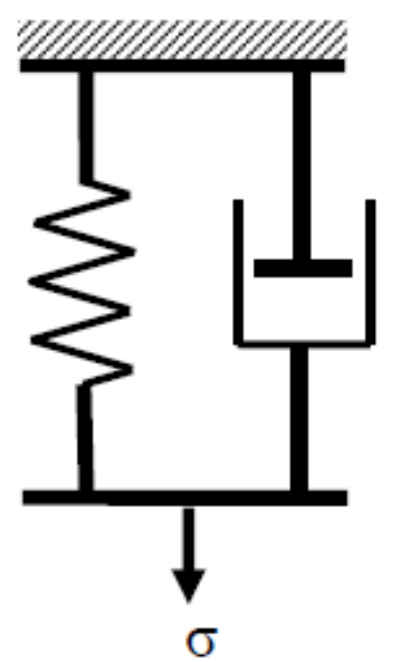

Figura 2-27 - Diagrama básico do modelo de kelvin. Fonte: YEO (2007). 
A Equação 2.5 representa o modelo de Kelvin.

$$
\sigma(t)=E \varepsilon(s)+\eta \frac{d \varepsilon(t)}{d t}
$$

Onde:

$\sigma=$ tensão aplicada ao conjunto;

$\varepsilon=$ deformação;

$\mathrm{t}=$ tempo;

$\mathrm{E}=$ módulo de Young;

$\eta=$ viscosidade do material.

O modelo de Voigt (paralelo) apresenta desenvolvimento inicial da tensão no pistão. Através do movimento do pistão, a carga é parcialmente transferida para a mola, e a medida que essa transferência ocorre a taxa de fluência tende a diminuir, pois a taxa de deformação é proporcional à tensão no pistão. A Figura 2-28 ilustra o comportamento deste modelo de acordo com a variação em função do tempo.

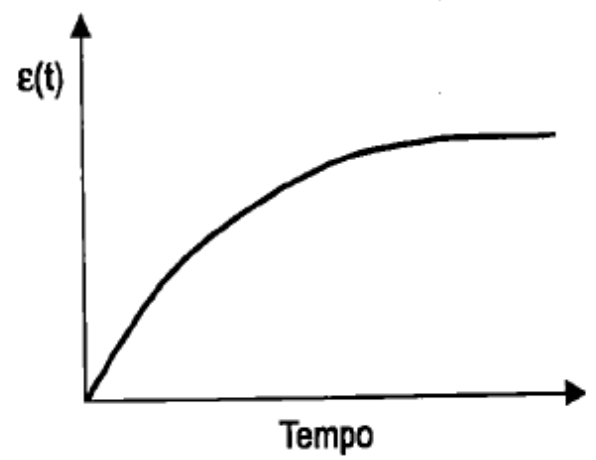

Figura 2-28 - Comportamento segundo modelo de VOIGT.

Um modelo reológico com resultados mais precisos que o anterior, para geotêxteis, é composto por uma série de molas e amortecedores em paralelos (Figura 2-29), é apresentado por KOERNER et al. (2001), e é conhecido por modelo Kelvin-Chain. 


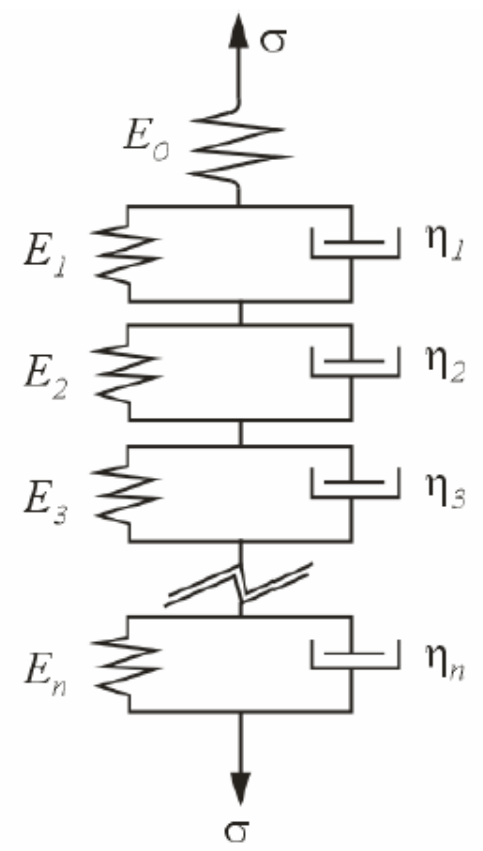

Figura 2-29 - Modelo reológico Kelvin-Chain. Fonte: KOERNER (2001).

A deformação total por fluência é obtida através da Equação 2.6.

$$
\varepsilon(t)=\sigma \cdot\left(E_{0}+\sum_{i=1}^{n} \frac{1}{E i} \cdot\left(1-e^{\frac{E i . t}{\eta i}}\right)\right)
$$

Onde:

$\sigma=$ deformação aplicada ao sistema;

$\mathrm{E}_{0}=$ módulo de elasticidade do elemento isolado;

$\mathrm{E}_{\mathrm{i}}=$ módulo de elasticidade do elemento;

$\eta_{\mathrm{i}}=$ viscosidade do material.

Este modelo é representado pela combinação em série entre o modelo puramente elástico de módulo de elasticidade $\mathrm{E}_{0}$ com modelos de Kelvin-Voigt de módulos de elasticidade $E_{\mathrm{i}}$ e viscosidade $\eta_{\mathrm{i}}$. Esta associação em série faz com que as diferentes partes do modelo apresentem a mesma tensão, sendo a deformação total $\boldsymbol{\varepsilon}(\boldsymbol{t})$ composta pela deformação do elemento de mola isolado somado com a deformação dos elementos de Kelvin-Voigt. 
Li \& Rowe (2001) investigou o comportamento de aterros reforçados com geossintéticos fabricados a partir de polímeros de PET, PP e PE, para isto, examinou a influência do comportamento viscoelástico dos materiais, levando em conta a variação da altura do aterro, o tipo de solo de fundação e diferentes períodos de construção e utilização do aterro. O modelo utilizado para descrever o comportamento viscoelástico foi o Multi-Kelvin (Kelvin-Chain), pois, segundo o autor, este modelo adequa-se facilmente ao estudo da fluência para vários períodos de tempo, sendo necessária uma menor quantidade de parâmetros dos materiais.

O material geossintético foi modelado em um software de elementos finitos com comportamento viscoelástico unidimensional, e a interação entre o solo e o reforço foi assumida através do critério de Mohr-Coulomb com a utilização de um ângulo de atrito para a interface da superfície entre o solo e o reforço. Foram examinados o comportamento dependente do tempo para quatro geossintéticos.

O autor avaliou a tensão de fluência ocorrida após a construção de um aterro e suas deformações induzidas através da fundação composta por solo mole. Segundo modelos criados, Li \& Rowe (2001) pode identificar a influência do comportamento viscoso do reforço na estabilidade do talude, para períodos de curto prazo.

Como resultado, observou-se que os fenômenos de fluência e de relaxação dos materiais aumentam as deformações causadas por tensão cisalhante na interface solo/reforço. Em contra partida, o reforço demonstra um ganho de força resistente após o período de construção do aterro.

Foi verificado que durante as construções dos aterros, o reforço pode apresentar característica menos rígida se comparado aos resultados obtidos através de ensaios desenvolvidos segundo a norma ASTM D 4595. O método de projeto baseado nas isócronas de rigidez para final de construção demonstrou ser um método seguro e conservador. 


\subsubsection{Equação de Arrhenius e equação de Williams-Landel-Ferry}

O Stepped Isothermal Method (S.I.M.) consiste em um ensaio que utiliza temperaturas elevadas, a extrapolação da fluência em altas temperaturas pode ser feita com o auxílio de alguns métodos que facilitam a interpretação dos resultados obtidos nos ensaios. Equações como a de Arrhenius e a Equação de Williams, Landel e Ferry são exemplos que podem explicar as reações que regem os materiais viscoelásticos.

A Equação de Arrhenius se baseia no comportamento dos gases e na relação entre reações químicas e a temperatura. Ela pode ser utilizada para extrapolação em geotêxteis, pois este composto apresenta característica viscoelástica e os fenômenos de degradação estão relacionados com o aumento da temperatura.

BARAS (2001) retrata a aplicação desta equação para a obtenção das taxas de fluência $\left(\varepsilon^{\prime}\right)$ em tempos além dos ensaiados em geotêxteis. A Equação 2.7 é uma relação de Arrhenius com taxa de deformação por fluência.

$$
\operatorname{Ln}\left(\frac{\varepsilon_{1}^{\prime}}{\varepsilon_{2}^{\prime}}\right)=\left(\frac{E a t}{R}\right) \cdot\left[\left(\frac{1}{T_{2}}\right)-\left(\frac{1}{T_{1}}\right)\right]
$$

Onde:

$\varepsilon_{1}^{\prime}{ }_{1}$ e $\varepsilon_{2}^{\prime}$ são as taxas de deformação correspondentes a $\mathrm{T}_{1}$ e $\mathrm{T}_{2}$,

Eat $=$ energia de ativação $(\mathrm{J} / \mathrm{mol})$,

$\mathrm{R}=$ constante universal dos gases $(8,314 \mathrm{~J} / \mathrm{K} . \mathrm{mol})$.

Uma dificuldade encontrada na Equação de Arrhenius é a obtenção da energia de ativação, por isso o SIM trabalha com poucas variações de temperatura, para isto as deformações, que ocorrem antes e imediatamente depois da mudança de temperatura, são aplicadas à Equação 2.7 obtendo assim as energias de ativação.

Para ensaios do tipo SIM, onde o corpo de prova fica sujeito a uma mesma tensão, e a variante é o aumento de temperatura. A Equação de Williams-Landel-Ferry (WLF) possibilita a criação de uma única curva mestra através de translações horizontais, ou seja, uma translação do tempo em função da temperatura (COSTANZI, 2003). 
A curva mestra resulta a partir da translação no eixo do tempo, através de um fator de translação denominado $\alpha_{\mathrm{t}}$, sendo $\alpha_{\mathrm{t}}$ uma função das temperaturas de referência e das temperaturas de execução do ensaio (BARAS, 2001).

A Equação de WLF nos mostra um modo empírico para encontrar o fator de translação $\alpha_{t}$, segundo a Equação 2.8.

$$
\log \left(\alpha_{t}\right)=\left(\frac{-C_{1}\left(T-T_{0}\right)}{\left(C_{2}+T-T_{0}\right)}\right)
$$

Sendo:

$\mathrm{C}_{1}$ e $\mathrm{C}_{2}=$ constantes que dependem do material utilizado;

$\mathrm{T}=$ temperatura do ensaio;

$\mathrm{T}_{0}=$ temperatura de referência.

Existem inúmeras formas de demonstrar os resultados obtidos pelos ensaios de fluência, cada maneira é escolhida de acordo com o que se pretende exemplificar, e cada uma apresenta sua vantagem. A maioria destas representações é constituída por modelos correlacionados ao tempo.

Os modelos correlacionados com o tempo podem ser desenvolvidos com base em equações empíricas, modelos de curvas isócronas e modelos reológicos, entre outros.

COSTANZI (2003) cita que a forma de representação mais comum, utilizada entre os geotêxteis, é o desenvolvimento através de curvas deformação (\%) versus tempo, onde o tempo é representado em escala logarítmica.

Existe, também, o modelo que explicita a variação de deformação por fluência de acordo com o carregamento aplicado, para tempos pré-determinados, este tipo de curva é conhecido como curvas isócronas. 


\subsubsection{Curvas isócronas}

As curvas isócronas permitem observar como o geossintético se comporta para um determinado carregamento, em um determinado tempo de vida da obra. Tais curvas auxiliam no dimensionamento de estruturas reforçadas com geotêxteis, aonde determinar a solicitação de tração máxima ao qual o material sofrerá o carregamento é um dos fatores mais importantes do projeto.

Para a obtenção das isócronas alguns procedimentos devem ser seguidos. O nível de carregamento deve ser definido, normalmente os carregamentos se encontram em um intervalo de 10 a $60 \%$ da resistência máxima média a tração do material. Após escolhido os diferentes carregamentos, procede-se com vários ensaios de fluência no geotêxtil, para obtenção de dados necessários a formação das curvas.

Os dados obtidos nos ensaios são, então, plotados em um gráfico de deformação versus tempo, uma vez obtido o gráfico, encontram-se as curvas para cada nível de carregamento (Figura 2-30 (a)). O procedimento para encontrar as isócronas inicia-se por intermédio da escolha de um valor de tempo do ensaio (t).

Para o tempo determinado anteriormente, são encontrados os valores de deformação de cada carregamento do corpo de prova. Os resultados são transformados e plotados em um gráfico de carregamento aplicado versus deformação, e repetem-se estas ações para outros tempos desejados de ensaio. A Figura 2-30 (b) ilustra o procedimento para a obtenção das isócronas. Sendo " $\varepsilon$ " as deformações, "t' o tempo e “Q” o carregamento. 

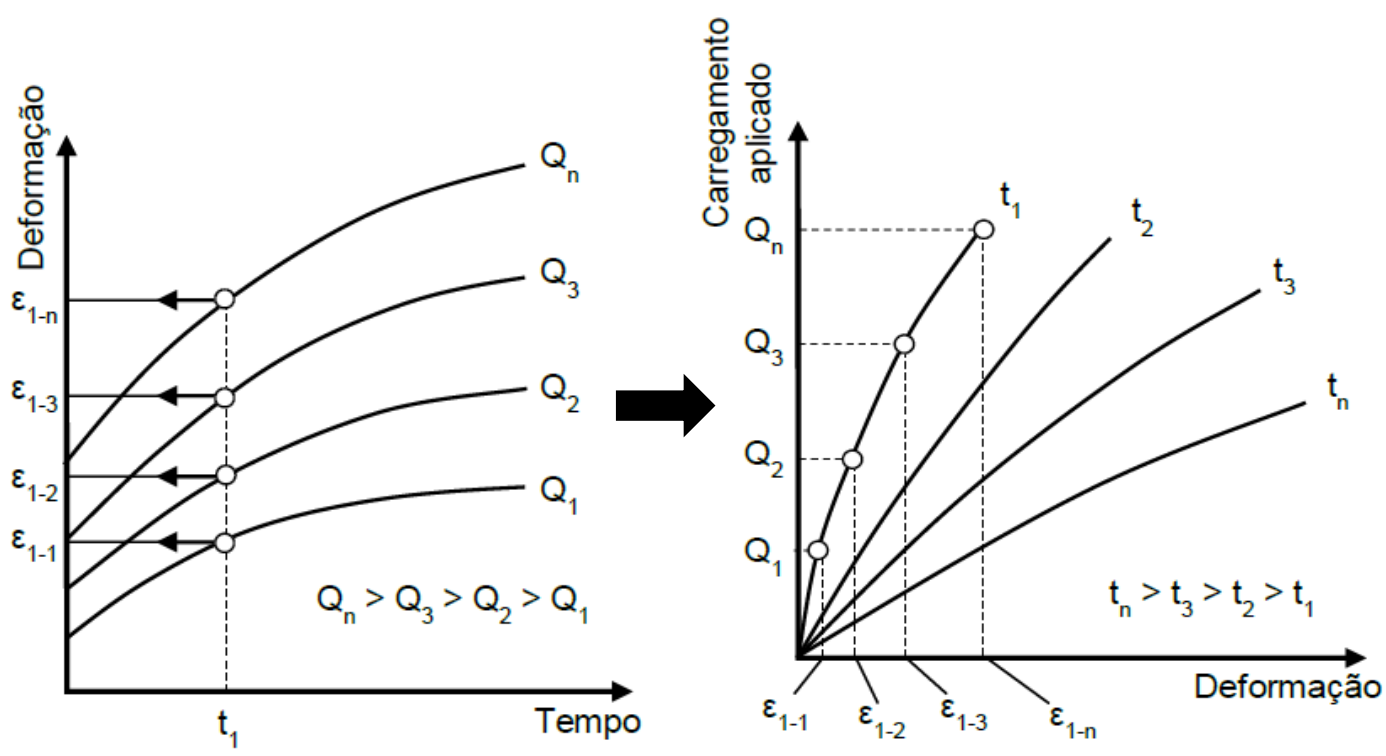

Figura 2-30 - a) tempo-deformação; b) deformação-carregamento aplicado (isócrona). 


\section{MATERIAIS E MÉTODOS}

Este capítulo apresenta os ensaios de caracterização e os resultados para os dois tipos de materiais utilizados no estudo, bem como a descrição dos equipamentos e os procedimentos utilizados na execução dos diferentes ensaios de fluência realizados.

Os dois geotêxteis não tecidos utilizados nesta pesquisa foram fabricados a partir do processo de agulhamento de fibras de poliéster. Eles se diferem quanto ao tamanho das fibras, sendo um deles produzido com filamentos contínuos e o outro com fibras curtas. A Tabela 3-1 resume suas características.

Tabela 3-1 - Geotêxteis analisados.

\begin{tabular}{c|c|c}
\hline Características de Fabricação & GTnwL & GTnwS \\
\hline Matéria-prima & Poliéster (PET) & Poliéster (PET) \\
Tipo de fibras & Filamamento Contínuos & Curtas \\
Estruturas & Agulhada & Agulhada \\
\hline
\end{tabular}

\subsection{CARACTERIZAÇÃO DOS GEOTÊXTEIS NÃO TECIDOS}

A caracterização física e mecânica dos dois geotêxteis foi realizada com base nas recomendações normativas prescritas pela American Society for Testing and Materials - ASTM e também pela Associação Brasileira de Normas Técnicas - ABNT. Os ensaios foram realizados no Laboratório de Geossintéticos do Departamento de Geotecnia, na Escola de Engenharia de São Carlos, EESC-USP. A seguir, apresentamse os resultados de alguns ensaios realizados.

O ensaio para medir a massa por unidade de área (ABNT NBR 12568) é um ensaio de caracterização física do material. A finalidade deste ensaio é determinar a massa por unidade de área do geossintético. A determinação da massa por unidade de área é simples e rápida, com no mínimo 10 corpos de prova, cada uma com $100 \mathrm{~cm}^{2}$, são pesadas em uma balança com precisão de 0,01g. A massa por unidade de área é o resultado da razão entre a massa do corpo de prova, pela sua área $\left(\mathrm{g} / \mathrm{m}^{2}\right)$. 
A Tabela 3-2 apresenta os resultados obtidos para o ensaio de massa por unidade de área do geotêxtil não tecido de fibra curta.

Tabela 3-2 - Espessura e massa por unidade de área - GTnwS.

\begin{tabular}{c|c|c|c}
\hline $\mathbf{C P}$ & Espessura $(\mathbf{m m})$ & Massa $(\mathbf{g})$ & $\begin{array}{c}\text { Massa por unidade } \\
\text { de área }\left(\mathbf{g} / \mathbf{m}^{\mathbf{2}}\right)\end{array}$ \\
\hline 1 & 2,73 & 3,60 & 360 \\
2 & 3,00 & 3,96 & 396 \\
3 & 2,89 & 4,02 & 402 \\
4 & 3,25 & 4,28 & 428 \\
5 & 3,21 & 4,42 & 442 \\
6 & 3,25 & 4,39 & 439 \\
7 & 2,94 & 3,98 & 398 \\
8 & 2,78 & 3,52 & 352 \\
9 & 2,51 & 3,10 & 310 \\
10 & 2,58 & 3,16 & 316 \\
\hline$\mu(\mathrm{mm})$ & 2,91 & $\mu\left(\mathrm{g} / \mathrm{m}^{2}\right)$ & 384 \\
$\sigma(\mathrm{mm})$ & 0,27 & $\sigma\left(\mathrm{g} / \mathrm{m}^{2}\right)$ & 47,94 \\
$v(\%)$ & 9,23 & $v(\%)$ & 12,48 \\
\hline
\end{tabular}

Já a Tabela 3-3 exibe os resultados obtidos para a caracterização do geotêxtil de filamento contínuo quanto a sua massa por unidade de área média.

Através destes resultados, podemos constatar que o material constituído de fibra curta apresenta espessura média e massa por unidade de área média maiores que o observado pelo espécime de filamento contínuo. Em contra partida, o material produzido através da fabricação por filamento contínuo apresenta um comportamento mais estável quanto ao coeficiente de variação e o desvio padrão da massa por unidade de área. Estas divergências nas características dois tipos de geotêxteis são devidas aos diferentes processos de fabricação aos quais os produtos são submetidos. 
Tabela 3-3 - Espessura e massa por unidade de área - GTnwL.

\begin{tabular}{c|c|c|c}
\hline $\mathbf{C P}$ & Espessura $(\mathbf{m m})$ & Massa $(\mathbf{g})$ & $\begin{array}{c}\text { Massa por unidade } \\
\text { de área }\left(\mathbf{g} / \mathbf{m}^{2}\right)\end{array}$ \\
\hline 1 & 2,67 & 2,64 & 264 \\
2 & 2,18 & 2,24 & 224 \\
3 & 2,38 & 2,68 & 268 \\
4 & 2,39 & 2,70 & 270 \\
5 & 2,13 & 2,41 & 241 \\
6 & 2,72 & 3,04 & 304 \\
7 & 2,31 & 2,63 & 263 \\
8 & 2,93 & 2,93 & 293 \\
9 & 2,94 & 3,00 & 300 \\
10 & 2,48 & 2,62 & 262 \\
\hline$\mu(\mathrm{mm})$ & 2,51 & $\mu\left(\mathrm{g} / \mathrm{m}^{2}\right)$ & 269 \\
$\sigma(\mathrm{mm})$ & 0,29 & $\sigma\left(\mathrm{g} / \mathrm{m}^{2}\right)$ & 25,13 \\
$v(\%)$ & 11,53 & $\nu(\%)$ & 9,34 \\
\hline
\end{tabular}

Os ensaios de caracterização mecânica realizados para estes materiais foram: Resistência ao puncionamento (ABNT NBR 13359), Resistência ao rasgo trapezoidal (ASTM D 4533), Resistência ao puncionamento (ASTM D 4833), Resistência à tração tipo "GRAB" (ASTM D 4632). A resistência à tração em faixa larga (ABNT NBR 12824) será descrita no subcapitulo 3.2, bem como seus resultados.

O ensaio "GRAB" é um método que fornece um índice para determinar a carga de ruptura (força GRAB) dos geotêxteis. A norma americana ASTM D 4632 dita os procedimentos e cuidados a serem tomados neste tipo de ensaio. Os resultados obtidos neste tipo de ensaio só podem ser utilizados para comparação entre geotêxteis com estruturas semelhantes, isto porque cada estrutura apresenta um tipo de comportamento único neste ensaio. O ensaio GRAB pode ser utilizado como um procedimento de controle de qualidade do material, os resultados dos ensaios podem ser vistos nas Tabelas 3-4 e 3-5. 
Tabela 3-4 - Ensaio GRAB para GTnwS PET, segundo a ASTM D 4632 (2008).

\begin{tabular}{c|c|c|c|c}
\hline Sentido & \multicolumn{2}{|c}{ Longitudinal } & \multicolumn{2}{c}{ Transversal } \\
\hline $\mathbf{C P}$ & $\mathbf{F}_{\text {máx }}(\mathbf{N})$ & $\boldsymbol{\varepsilon}_{\text {long }}(\boldsymbol{\%})$ & $\mathbf{F}_{\text {máx }}(\mathbf{N})$ & $\boldsymbol{\varepsilon}_{\text {trans }}(\boldsymbol{\%})$ \\
\hline 1 & 775,8 & 77,66 & 665,5 & 112,30 \\
2 & 853,9 & 84,79 & 711,3 & 100,10 \\
3 & 969,3 & 99,11 & 935,4 & 101,30 \\
4 & 962,6 & 93,89 & 1076,0 & 93,45 \\
5 & 862,4 & 92,12 & 940,5 & 86,23 \\
6 & 582,3 & 82,11 & 994,8 & 88,88 \\
7 & 718,1 & 90,47 & 862,4 & 88,68 \\
8 & 728,3 & 88,56 & 765,6 & 89,88 \\
9 & 623,0 & 81,78 & 752,1 & 82,22 \\
10 & 702,8 & 86,00 & 780,9 & 81,55 \\
\hline $\boldsymbol{\mu}$ & 777,90 & 87,65 & 848,50 & 92,47 \\
$\boldsymbol{\nu}(\boldsymbol{\%})$ & 17,01 & 7,36 & 15,84 & 10,38 \\
\hline
\end{tabular}

Tabela 3-5 - Ensaio GRAB para GTnwL PET, conforme a ASTM D 4632 (2008).

\begin{tabular}{c|c|c|c|c}
\hline Sentido & \multicolumn{2}{|c}{ Longitudinal } & \multicolumn{2}{c}{ Transversal } \\
\hline $\mathbf{C P}$ & $\mathbf{F}_{\text {máx }}(\mathbf{N})$ & $\boldsymbol{\varepsilon}_{\text {long }}(\boldsymbol{\%})$ & $\mathbf{F}_{\text {máx }}(\mathbf{N})$ & $\boldsymbol{\varepsilon}_{\text {trans }}(\boldsymbol{\%})$ \\
\hline 1 & 908,2 & 81,90 & 994,8 & 81,34 \\
2 & 1185,0 & 81,46 & 1075,0 & 83,99 \\
3 & 860,7 & 60,10 & 843,7 & 71,56 \\
4 & 1020,0 & 71,79 & 843,7 & 72,77 \\
5 & 1086,0 & 67,44 & 1110,0 & 80,90 \\
6 & 1008,0 & 69,79 & 1114,0 & 76,45 \\
7 & 957,5 & 63,78 & 903,1 & 74,45 \\
8 & 1107,0 & 76,21 & 877,7 & 79,57 \\
9 & 881,1 & 76,13 & 857,3 & 76,21 \\
10 & 665,5 & 65,58 & 730,0 & 75,45 \\
\hline $\boldsymbol{\mu}$ & 968,00 & 71,32 & 934,90 & 77,27 \\
$\boldsymbol{\nu}(\boldsymbol{\%})$ & 15,36 & 10,40 & 14,02 & 5,22 \\
\hline
\end{tabular}

A norma NBR 13359 se refere ao ensaio de resistência ao puncionamento estático - ensaio com o pistão tipo CBR, pois o equipamento utilizado para o ensaio é similar ao pistão do Índice de Suporte Califórnia (CBR). O número mínimo de corpos de prova ensaiados é de cinco elementos. A penetração máxima do produto é dada pela média aritmética da penetração de cada elemento. A Tabela 3-6 contém os resultados para os dois produtos. 
Tabela 3-6 - Ensaio de Puncionamento Estático, de acordo com a NBR 13359 (1993).

\begin{tabular}{c|c|c|c}
\hline Geotêxtil & $\mathbf{C P}$ & $\mathbf{F}_{\text {máx }}(\mathbf{k N})$ & $\mathbf{d}(\mathbf{m m})$ \\
\hline \multirow{5}{*}{ GTnwS } & 1 & 2,09 & 65,67 \\
& 2 & 2,59 & 61,48 \\
& 3 & 2,43 & 57,75 \\
& 4 & 1,83 & 62,15 \\
& 5 & 2,79 & 70,74 \\
\hline & $\mu$ & 2,35 & 63,56 \\
& $v(\%)$ & 16,38 & 7,71 \\
\hline \multirow{5}{*}{ GTnwL } & 1 & 2,52 & 48,49 \\
& 2 & 2,86 & 50,11 \\
& 3 & 2,82 & 49,40 \\
& 4 & 3,19 & 48,85 \\
& 5 & 2,62 & 47,45 \\
\cline { 2 - 4 } & $\mu$ & 2,80 & 48,86 \\
& $\nu(\%)$ & 9,16 & 2,04 \\
\hline
\end{tabular}

O geotêxtil de filamento contínuo apresenta uma resistência média ao puncionamento maior que o fabricado por fibra curta, em contra partida a deformação suportada pelo produto de fibra curta é superior em mais de $30 \%$ da deformação do material de filamento contínuo. Isto demonstra uma maior resistência aos danos de instalação do elemento de filamento contínuo, pois quando em confinamento com o solo, este produto apresenta uma menor deformação da estrutura em geral, e somado a isto o material resiste a maiores tensões devido ao puncionamento que pode ocorrer pelo confinamento com elementos heterogêneos.

O ensaio preconizado pela norma americana (ASTM D 4833) é usado para medir o índice de resistência à punção dinâmica dos geotêxteis. Na realização deste ensaio, deve-se tomar cuidado para que não ocorra o deslizamento do corpo de prova através do anel de fixação.

O resultado do ensaio é a maior força registrada pelo equipamento para que ocorra a perfuração do geotêxtil. Para ensaios onde os fios do material não se rompam ou a sonda deslize entre os fios, os resultados obtidos devem ser descartados e o mesmo deve ser feito em ensaios onde ocorra o escorregamento do corpo de prova. 
A Tabela 3-7 apresenta os valores obtidos no ensaio recomendado pela ASTM D 4833 (2000). Da mesma maneira como observado anteriormente através dos resultados obtidos pelo ensaio com a norma brasileira ABNT NBR 13359, observa-se uma resistência maior ao puncionamento pelo exemplar de filamento continuo, e uma deformação maior no produto de filamento curto.

Tabela 3-7 - Punção de GTnw PET, segundo norma ASTM D 4833 (2000).

\begin{tabular}{c|c|c|c|c}
\hline Tipo de fibra & \multicolumn{2}{|c|}{ GTnwS } & \multicolumn{2}{c}{ GTnwL } \\
\hline $\mathbf{C P}$ & $\mathbf{F}_{\text {máx }}(\mathbf{N})$ & $\mathbf{d}(\mathbf{m m})$ & $\mathbf{F}_{\text {máx }}(\mathbf{N})$ & $\mathbf{d}(\mathbf{m m})$ \\
\hline 1 & 537,3 & 17,70 & 474,6 & 14,35 \\
2 & 537,0 & 18,87 & 507,2 & 13,63 \\
3 & 583,6 & 17,87 & 648,5 & 16,20 \\
4 & 596,0 & 18,87 & 569,8 & 14,89 \\
5 & 512,1 & 17,87 & 519,7 & 13,92 \\
6 & 548,5 & 18,20 & 503,3 & 13,82 \\
7 & 612,8 & 19,20 & 447,0 & 14,16 \\
8 & 649,9 & 20,20 & 485,5 & 14,16 \\
9 & 428,1 & 18,37 & 536,6 & 13,97 \\
10 & 443,5 & 17,37 & 557,5 & 14,70 \\
11 & 448,3 & 18,20 & 479,4 & 13,66 \\
12 & 419,8 & 18,20 & 566,3 & 14,25 \\
13 & 426,6 & 17,37 & 577,1 & 15,25 \\
14 & 407,8 & 18,20 & 546,2 & 14,80 \\
15 & 307,8 & 16,87 & 511,4 & 14,56 \\
\hline $\boldsymbol{\mu}$ & 497,30 & 18,22 & 528,70 & 14,42 \\
$\boldsymbol{( 1 \% )}$ & 18,99 & 4,53 & 9,65 & 4,73 \\
\hline
\end{tabular}

O método do rasgo trapezoidal (ASTM D 4533) é um ensaio utilizado para medir a força necessária para ocorrer à propagação de um rasgo no geotêxtil, podendo este ensaio ser aplicado a diferentes tipos de geotêxteis. O ensaio de rasgo produz uma tensão ao longo de um caminho preferencial, fazendo com que o rasgo se propague através da largura do corpo de prova. Este método permite estimar a resistência ao rasgo relativo a diferentes direções no espécime.

$\mathrm{Na}$ aplicação deste método foram feitos ensaios nos dois sentidos das fibras (sentido transversal e sentido longitudinal), pois os geotêxteis apresentam valores de resistências diferenciados que dependem da direção ao qual a tensão é aplicada.

Os valores obtidos no ensaio do rasgo trapezoidal (ASTM D 4533) estão explicitados na Tabela 3-8. 
Tabela 3-8 - Resistência ao Rasgo, de acordo com a ASTM D 4533 (1991).

\begin{tabular}{c|c|c|c|c}
\hline Geotêxtil & \multicolumn{2}{|c|}{ GTnwS } & \multicolumn{2}{c}{ GTnwL } \\
\hline $\mathbf{C P}$ & $\mathbf{F}_{\text {máx, long }}(\mathbf{N})$ & $\mathbf{F}_{\text {máx, trans }}(\mathbf{N})$ & $\mathbf{F}_{\text {máx, long }}(\mathbf{N})$ & $\mathbf{F}_{\text {máx, trans }}(\mathbf{N})$ \\
\hline 1 & 512,7 & 325,9 & 548,3 & 281,8 \\
2 & 585,7 & 331,0 & 521,2 & 602,7 \\
3 & 531,4 & 544,9 & 441,4 & 553,4 \\
4 & 495,7 & 538,1 & 497,4 & 470,2 \\
5 & 497,4 & 439,7 & 439,7 & 519,5 \\
6 & 427,8 & 322,6 & 495,7 & 584,0 \\
7 & 497,4 & 261,4 & 407,4 & 385,4 \\
8 & 426,1 & 361,6 & 327,6 & 436,3 \\
9 & 353,1 & 404,0 & 370,1 & 422,7 \\
10 & 429,5 & 271,6 & 370,1 & 363,3 \\
\hline $\boldsymbol{\mu}$ & 475,70 & 380,10 & 441,90 & 461,90 \\
$\boldsymbol{\nu}(\%)$ & 13,98 & 26,47 & 16,55 & 22,44 \\
\hline
\end{tabular}

Foram ensaiados 10 corpos de prova para cada sentido e para cada tipo de material, totalizando um número de 40 ensaios de rasgo trapezoidal. O geotêxtil de filamento contínuo apresentou valores de resistência semelhantes nos dois sentidos da fibra ou do filamento. Já o geotêxtil não tecido de fibra curta apresentou uma resistência maior no sentido longitudinal da fibra se comparado ao sentido transversal do mesmo produto.

\subsection{ENSAIO DE TRAÇÃO MÁXIMA}

O equipamento utilizado para este ensaio foi a máquina universal INSTRON, e pode ser visualizada na Figura 3-1. A máquina é constituída de garras de fixação rotativas com a finalidade de prender o corpo de prova e evitar o deslizamento do mesmo, impedindo a ruptura do material junto às garras. $\mathrm{O}$ sistema de carregamento é rígido e impede variações da carga aplicada.

Os corpos de prova ensaiados apresentavam dimensões de 1,0 × 0,2 metros. $\mathrm{O}$ material era fixado nas garras rotativas, e a eles era aplicado uma pré carga a fim de eliminar a folga existente no material, facilitando assim uma melhor leitura da deformação com o valor da carga aplicada pelo equipamento. 


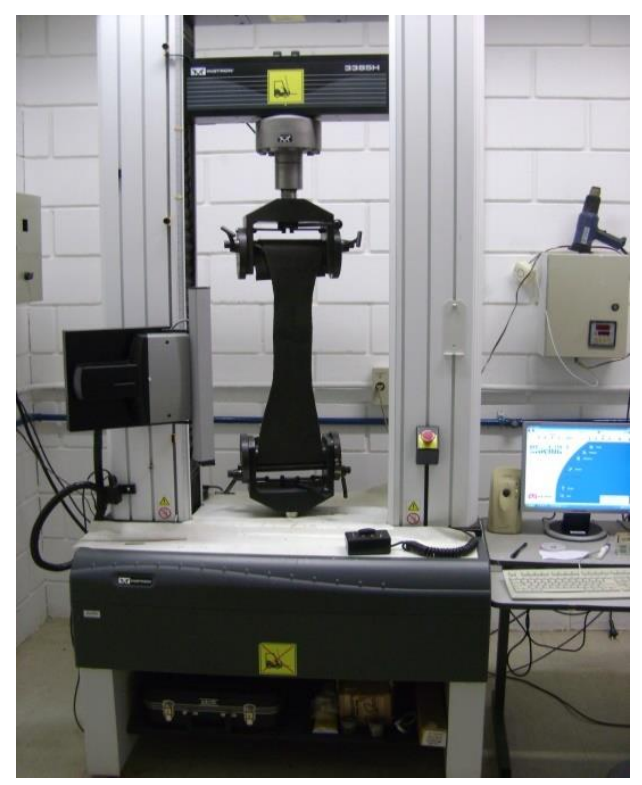

Figura 3-1 - Equipamento utilizado para obter a carga de ruptura, INSTRON.

Para o ensaio de carga por ruptura, foram utilizados dez corpos de prova para cada tipo de material, a finalidade era encontrar o valor médio de tração máximo suportado pelo geotêxtil, bem como suas dispersões em torno da média. Neste ensaio foi arbitrado que os geotêxteis seriam ensaiados no sentido longitudinal de fabricação, e assim, por conseguinte os ensaios de fluência ocorreriam no sentido longitudinal com porcentagens da carga média máxima encontrada.

A Tabela 3-9 demonstra os resultados obtidos para o geotêxtil de fibra curta no sentido longitudinal de fabricação. Já a Tabela 3-10 mostra os resultados obtidos para o geotêxtil de filamento contínuo, para o sentido longitudinal de fabricação. 
Tabela 3-9- Tração máxima - GTnwS.

\begin{tabular}{c|c|c|c}
\hline $\mathbf{C P}$ & $\mathbf{F}_{\text {máx }}(\mathbf{k N})$ & $\mathbf{F} / \mathbf{L}(\mathbf{N} / \mathbf{m m})$ & $\mathbf{e}(\boldsymbol{\%})$ \\
\hline 1 & 2,4 & 12,1 & 65,5 \\
2 & 2,2 & 10,8 & 53,5 \\
3 & 3,1 & 15,7 & 61,7 \\
4 & 3,0 & 15,1 & 60,1 \\
5 & 2,3 & 11,5 & 55,8 \\
6 & 2,1 & 10,3 & 56,2 \\
7 & 2,3 & 11,4 & 61,8 \\
8 & 2,3 & 11,7 & 62,7 \\
9 & 2,6 & 13,2 & 71,4 \\
10 & 3,0 & 14,8 & 52,6 \\
\hline $\boldsymbol{\mu}$ & 2,5 & 12,6 & 60,1 \\
$\nu(\boldsymbol{\%})$ & 14,56 & 14,56 & 9,66 \\
$\mathbf{V}_{\text {máx }}$ & 3,1 & 15,7 & 71,4 \\
$\mathbf{V}_{\text {min }}$ & 2,1 & 10,3 & 52,6 \\
\hline
\end{tabular}

Tabela 3-10 - Tração máxima - GTnwL.

\begin{tabular}{c|c|c|c}
\hline $\mathbf{C P}$ & $\mathbf{F}_{\text {máx }}(\mathbf{k N})$ & $\mathbf{F} / \mathbf{L}(\mathbf{N} / \mathbf{m m})$ & $\mathbf{e}(\boldsymbol{\%})$ \\
\hline 1 & 3,0 & 15,0 & 51,3 \\
2 & 3,2 & 16,1 & 55,5 \\
3 & 3,3 & 16,7 & 52,5 \\
4 & 2,6 & 13,2 & 52,6 \\
5 & 3,0 & 15,1 & 49,6 \\
6 & 3,2 & 15,9 & 19,6 \\
7 & 3,2 & 15,8 & 50,9 \\
8 & 3,3 & 16,5 & 57,5 \\
9 & 2,3 & 11,4 & 49,2 \\
10 & 2,7 & 13,5 & 47,3 \\
\hline $\boldsymbol{\mu}$ & 2,98 & 14,91 & 48,61 \\
$\boldsymbol{v}(\boldsymbol{\%})$ & 11,35 & 11,35 & 21,82 \\
$\mathbf{V}_{\text {máx }}$ & 3,3 & 16,7 & 57,5 \\
$\mathbf{V}_{\text {min }}$ & 2,3 & 11,4 & 19,6 \\
\hline
\end{tabular}

Os valores obtidos para a carga de ruptura dos materiais, bem como as deformações induzidas nos corpos de prova através do equipamento INSTRON, apresentam resultados semelhantes (item 3.1).

Sendo assim, o material de filamento contínuo apresenta resistência a tração média, no sentido longitudinal, maior que o exemplar de fibra curta. E como visto anteriormente, o produto de poliéster fabricado a partir de fibras curtas tem um 
desempenho maior em deformar-se, atingindo o valor máximo de 71,4\% de deformação comparada com o comprimento inicial.

A Figura 3-2 mostra os valores do coeficiente de variação dos resultados dos ensaios de caracterização e tração máxima nos dois geotêxteis estudados GTnwS e GTnwL. É possível verificar que não houve uma tendência quanto ao valor do coeficiente nem em relação aos geotêxteis e nem em relação ao tipo de ensaio físico ou mecânico.

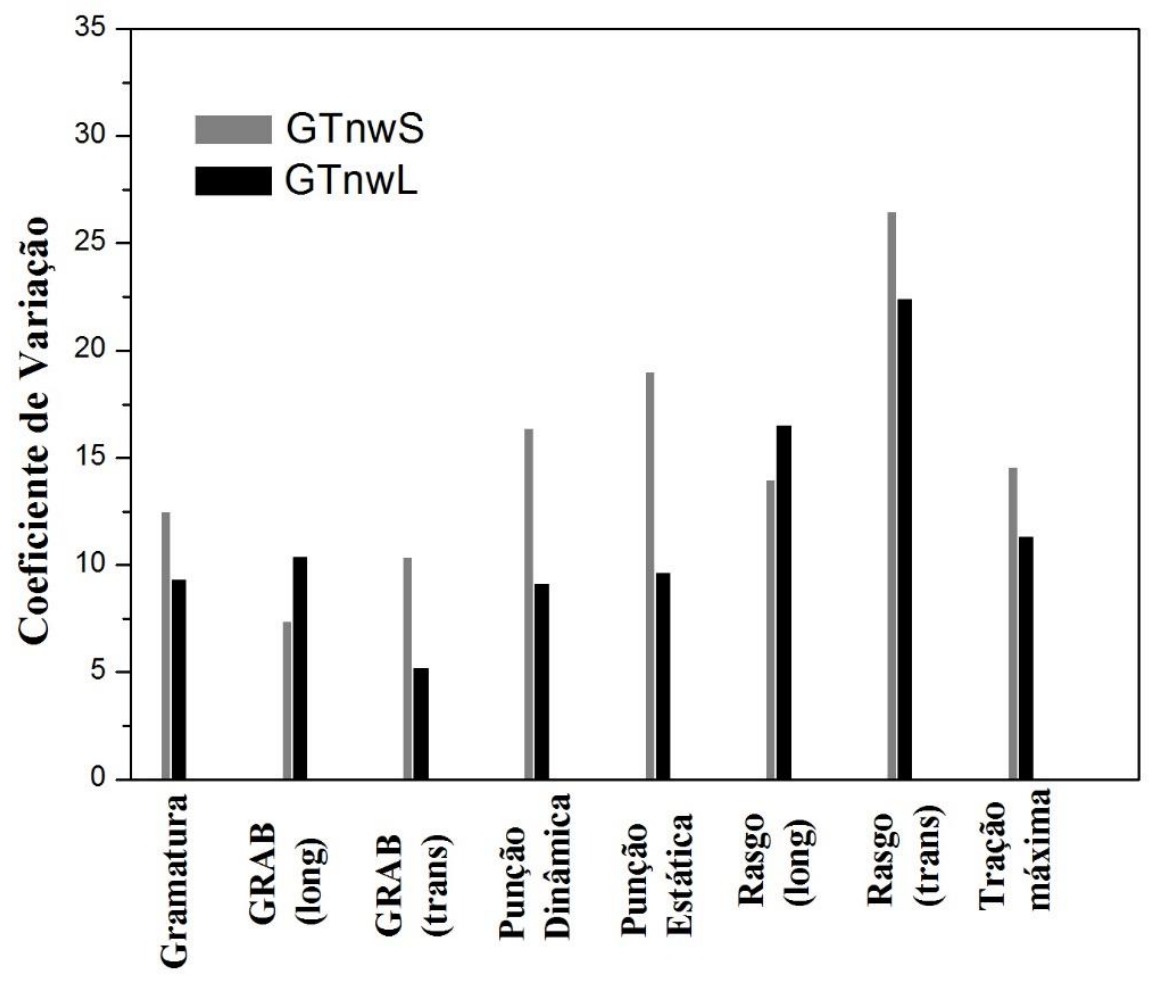

Figura 3-2 - Coeficiente de variação nos resultados dos ensaios dos geotêxteis.

\subsection{ENSAIO DE FLUÊNCIA CONVENCIONAL}

Segundo as recomendações da norma ABNT (NBR 15226, 2005), o corpo de prova deve ser condicionado em uma atmosfera padrão definida pela ISO 554, as características a resistência à tração deve ser determinada de acordo com a ABNT (NBR 12824), incluindo o alongamento e a contração lateral dos corpos de prova.

Os ensaios devem ser realizados em pelo menos quatro diferentes níveis de carga. Neste estudo os valores definidos são de 5\%,10\%, 20\%, 40\% e 60\% da resistência 
média das trações máximas medidas. Carregamento de 5\% e 10\% são valores próximos aos carregamentos suportados pelos geotêxteis em solo reforçado, isto quando os fatores de redução já foram aplicados ao cálculo do projeto.

A variação do comprimento, ao qual o geotêxtil sofre quando em carregamento, deve ser medida nos seguintes tempos de fluência: $1 \mathrm{~min}, 2 \mathrm{~min}, 4 \mathrm{~min}, 8 \mathrm{~min}, 15 \mathrm{~min}$, $30 \mathrm{~min}, 60 \mathrm{~min}, 2$ horas, 4 horas, 8 horas, 24 horas, 3 dias, 7 dias, 14 dias, 21 dias e 42 dias (que correspondem a um total de 1008 horas).

A deformação sofrida pelo geotêxtil deve ser medida com uma acurácia de $\pm 0,1 \%$ da variação do comprimento. Para tal deformação, um artifício utilizado nestes ensaios foi a utilização de quatro miras acopladas ao geotêxtil, onde a aferição da fluência é feita em relação ao deslocamento relativo entre essas miras, e outras 4 miras que servem de guia (coordenadas globais), e que se encontram fixadas em duas réguas indeslocáveis.

A Figura 3-3 mostra a configuração dos alvos para aferição da fluência, nela podemos destacar a composição das coordenadas indeslocáveis que são à base de criação de um plano de coordenadas para a comparação da deformação relativa às miras móveis. Estes deslocamentos foram tratados por meio de um software denominado TRATAMENTO.

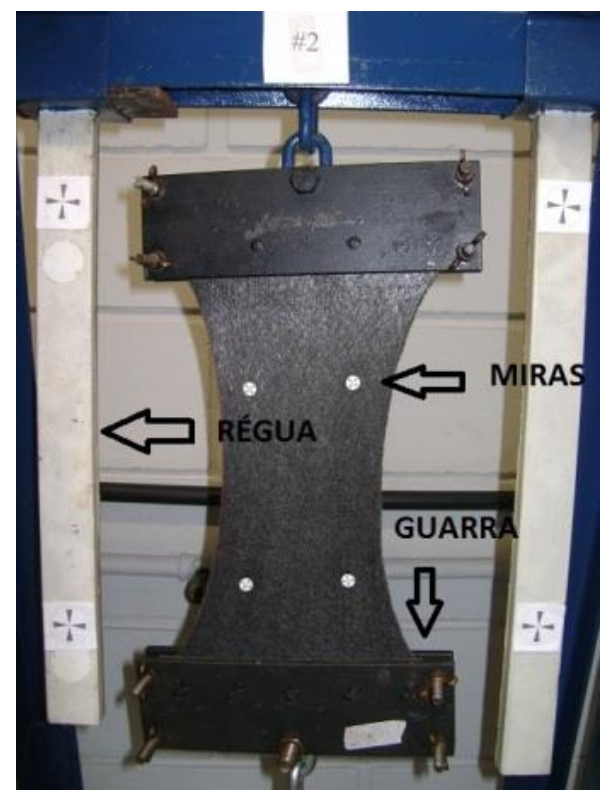

Figura 3-3 - Representação do ensaio de aferição da fluência. 
O tratamento será feito por meio de fotos tiradas nos tempos anteriormente citados. O deslocamento é quantificado através de porcentagem de deformação, ocorrida no geotêxtil, entre a foto inicial e a foto no instante pré-definido. Cada ensaio convencional gera um total de 17 fotos, sendo 16 fotos tiradas nos tempos determinados e uma foto (foto inicial ou foto de pré carga) tirada antes do início do ensaio, com o corpo de prova estando em posição no cavalete.

A foto de pré-carga serve como base para todo o tratamento, é de suma importância que o corpo de prova fique na posição exatamente paralela as miras globais, no momento da retirada desta foto, isto faz com que os erros de tratamentos sejam minimizados ao máximo. Com os resultados obtidos ao fim do tratamento, podemos traçar a curva deformação versus tempo para o geossintético ensaiado.

Para cada carga aplicada no corpo de prova $(5 \%, 10 \%, 20 \%, 40 \%$ e 60\%) foram realizados três ensaios de fluência convencional, exceto para o carregamento de 5\% que foram dois ensaios. Cada ensaio convencional tem uma duração de 42 dias, e o corpo de prova apresenta dimensões de 0,5 x 0,2 metros.

As garras utilizadas para fixação do geotêxtil no ensaio convencional, são compostas por um conjunto de quatro peças, sendo duas menores do tipo 1 (37 $\mathrm{mm} \mathrm{x}$ $240 \mathrm{~mm} \times 6,35 \mathrm{~mm}$ ) e duas maiores do tipo 2 (77 $\mathrm{mm} \times 240 \mathrm{~mm} \times 7,94 \mathrm{~mm}$ ), como descrito em BARAS (2001). A garra superior fica fixa ao cavalete, e é na garra inferior que o peso morto é acoplado, como mostra a Figura 3-4.

O equipamento utilizado no ensaio convencional de fluência é composto por cavaletes de aço com 1,60 metros de altura. Os cavaletes apresentam-se individualizados para que o ensaio não sofra perturbações geradas por algum outro ensaio de fluência e a carga em cada ensaio deve permanecer constante durante todo o intervalo de tempo de ocorrência do ensaio. A Figura 3-4 representa a aparência de um cavalete com um ensaio convencional sendo efetuado.

Alguns cuidados, como evitar o escorregamento do geotêxtil entre as garras e aplicar o carregamento suavemente em até $60 \mathrm{~s}$, devem ser tomados para que alguns fatores não influenciem na qualidade dos resultados. 


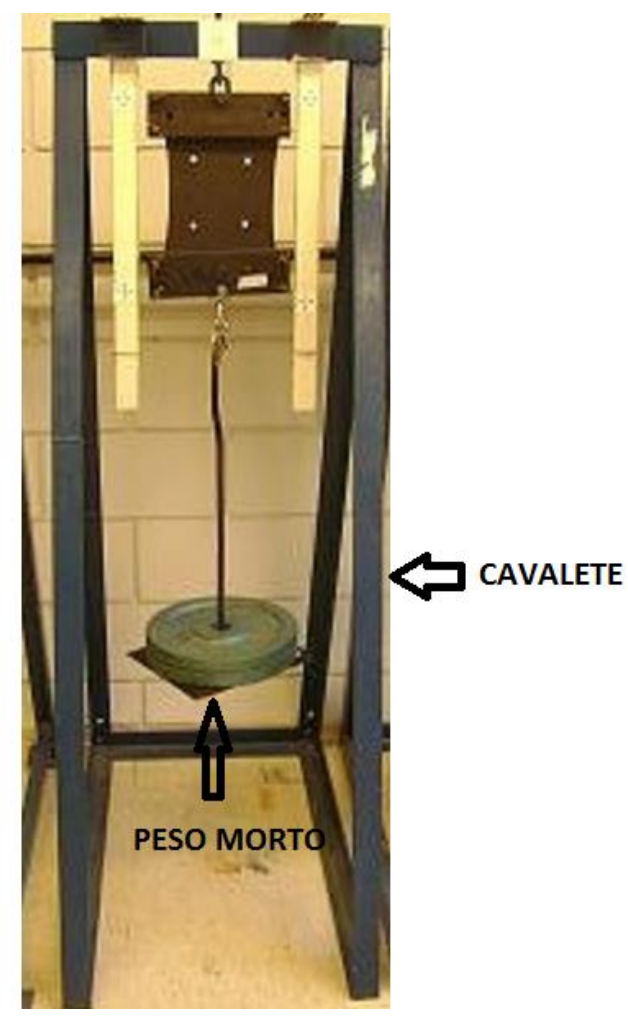

Figura 3-4 - Equipamento ensaio convencional.

\subsection{ENSAIO DE FLUÊNCIA ACELERADA (MÉTODO SIM)}

O SIM apresenta carregamento constante de uma única amostra, e tal solicitação é determinada através de uma porcentagem da tração máxima ao qual o material resiste, o corpo de prova fica exposto a incrementos de temperatura, sendo esses incrementos controlados pelo equipamento desenvolvido.

O equipamento idealizado por THORNTON, para aplicação do método SIM, foi desenvolvido e modificado para este estudo, e encontra-se no laboratório de Geossintéticos do Departamento de Geotecnia da Escola de Engenharia de São Carlos (EESC - USP). É composto por uma estrutura metálica, formada por uma câmara de temperatura controlada com isolamento térmico e por um cavalete para inserção do corpo de prova, a estrutura é complementada por réguas de referência que auxiliarão nas aquisições dos dados de fluência. A câmara de temperatura apresenta aberturas, do tipo janela com dobradiça, para facilitar a verificação do geotêxtil e também para aquisição de medidas da deformação por fluência. Em sua lateral apresenta uma porta deslizante que auxilia na montagem do ensaio e facilita o carregamento do geotêxtil. 
Como o ensaio necessita de altos gradientes de temperatura, e a variação de tal deve ocorrer em incrementos de tempo da ordem de um minuto, foi instalado um soprador de ar com capacidade de desenvolver altas temperaturas.

Para manter a temperatura constante em toda a câmara e controlar as subidas de temperatura em tempos específicos, foi utilizado um controlador (ver Figuras 3-5 e 3-6) da marca Flyever, em conjunto com um sensor Termopar que se posicionava junto ao geotêxtil para garantir que o corpo de prova mantivesse a temperatura programada sem apresentar oscilações maiores que as permitidas pela norma.

A Figura 3-6 demonstra como é a estrutura física que compõe o equipamento.
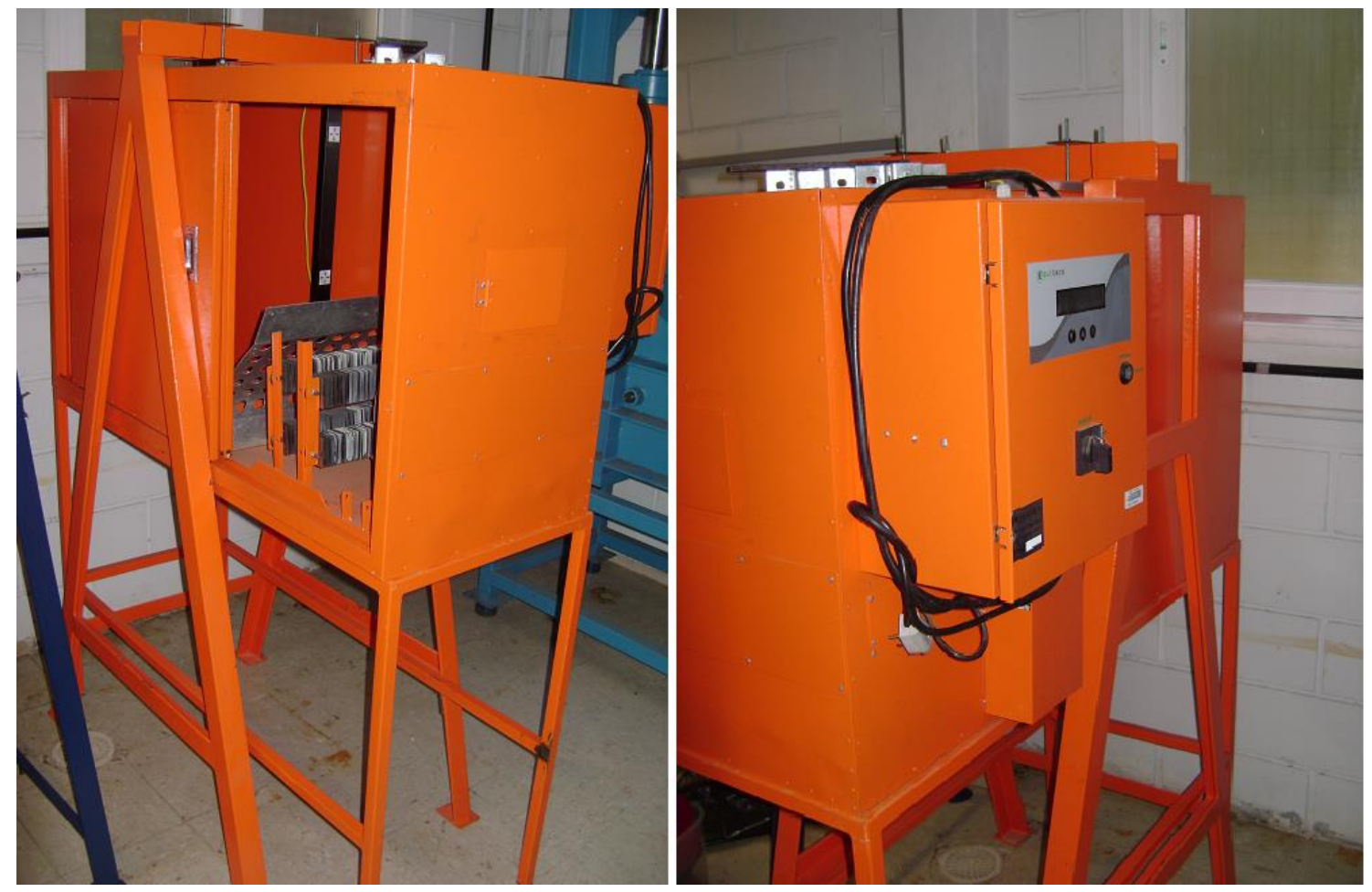

Figura 3-5 - Câmara térmica e controlador de temperatura 


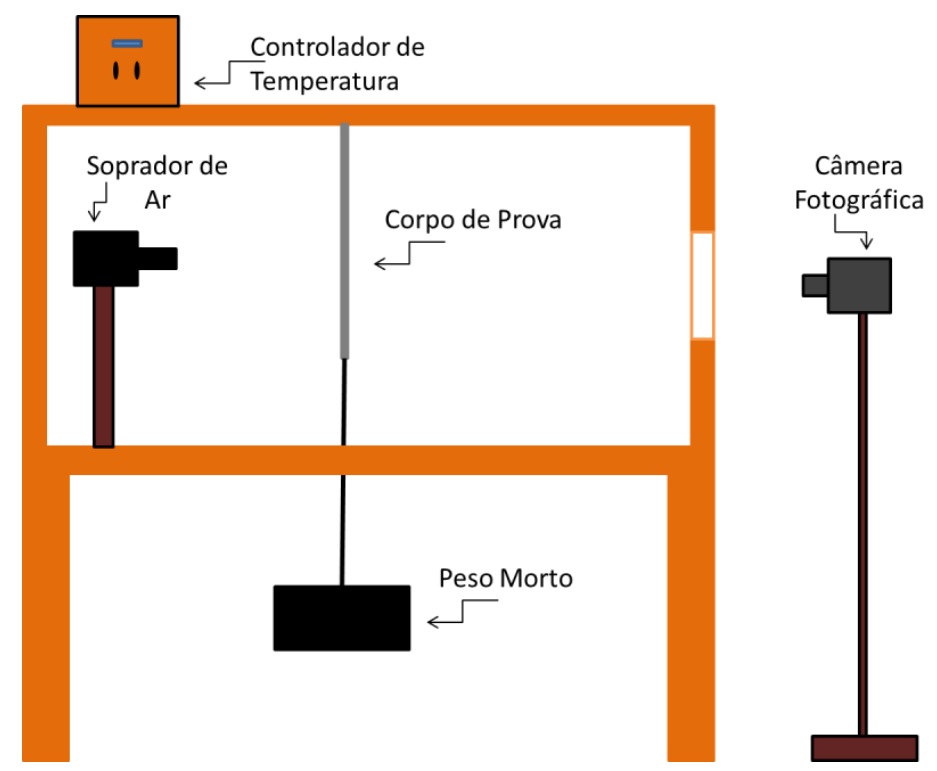

Figura 3-6 - Câmara térmica e controlador de temperatura

Os níveis de carregamentos definidos para os ensaios acelerados foram de 5\%, $10 \%, 20 \%, 40 \%$ e $60 \%$ da resistência média das trações máximas medidas, os mesmos realizados para os ensaios convencionais. Para cada carregamento foram realizados 4 ensaios acelerados e convencionais.

Os ensaios acelerados foram realizados em quatro etapas com duas horas de duração para cada, as temperaturas foram variando de etapa para etapa. O início do ensaio se assemelha com o ensaio convencional, pois a temperatura utilizada é a temperatura ambiente (neste caso, em média $30{ }^{\circ} \mathrm{C}$, pois era a temperatura recorrente na época dos ensaios), os outros patamares apresentavam temperaturas de 40,50 e $60{ }^{\circ} \mathrm{C}$, respectivamente.

Com a temperatura ambiente próxima de $30{ }^{\circ} \mathrm{C}$, as rampas de subida de temperatura apresentaram sempre proporcionais a um aumento de $10{ }^{\circ} \mathrm{C}$ de etapa para etapa, tomando o devido cuidado para que estas elevações fossem feitas dentro de um minuto.

As medidas de fluência eram tomadas através de fotografias retiradas nos tempos de: $1 \mathrm{~min}, 2 \mathrm{~min}, 4 \mathrm{~min}, 8 \mathrm{~min}, 15 \mathrm{~min}, 30 \mathrm{~min}, 60 \mathrm{~min}, 2$ horas para cada etapa. Cada ensaio do SIM gerava um total de 33 fotos, contabilizando a foto de pré carga inicial, e 
os dados obtidos eram tratados com o mesmo software utilizado no ensaio convencional.

Para gerar a curva de deformação versus tempo do material ensaiado, foram feitas as interpretações das transformações gráficas sugeridas por Thornton et. al. (1998), que estão explicitadas no capítulo da revisão bibliográfica. As curvas, do resultado inicial do ensaio SIM, sofreram transformações do tipo translações verticais e translações horizontais, bem como o estudo sobre o tempo inicial de cada patamar.

A seguir as Figuras, 3-7, 3-8 e 3-9 demonstram como foi o processo de transformação da curva inicial para a curva final, com alcance próximo de cem anos.

Inicialmente é calculado o tempo virtual de início de cada etapa com aumento de temperatura. $\mathrm{O}$ ajuste do tempo virtual é feito com a inclinação inicial dos primeiros minutos de cada incremento de temperatura. A escolha da inclinação influi diretamente no alcance da curva final. Para melhores resultados, a reta inclinada deve ser construída com os pontos entre 60 e 300 s. O tempo virtual de início da etapa é a diferença entre o tempo total da etapa e o tempo virtual encontrado. A Figura 3-7 ilustra como encontrar este tempo.

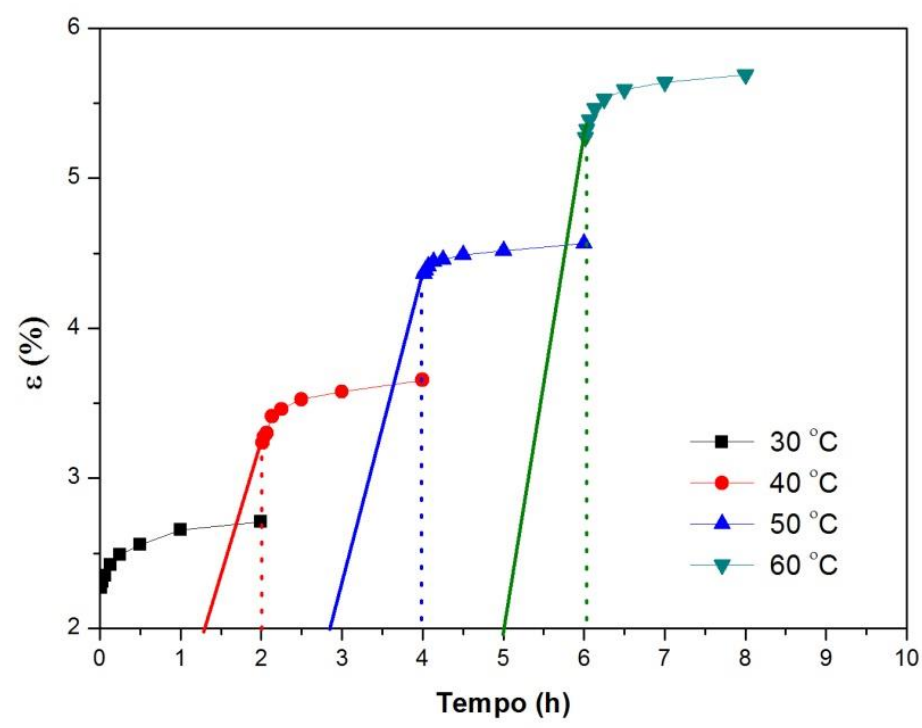

Figura 3-7 - Tempo virtual. 
Após encontrar o tempo de início de cada incremento de temperatura, os pontos de leitura devem então ser ajustados para os novos tempos, e o eixo das abcissas deve ser alterado para a escala logarítmica, o gráfico então fica com o formato da Figura 3-8.

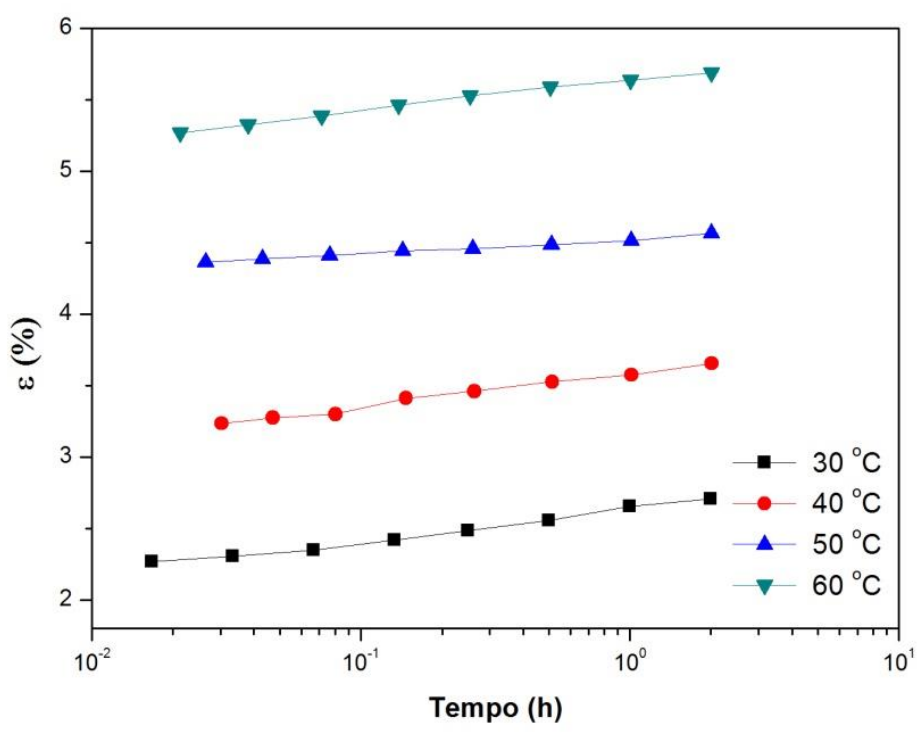

Figura 3-8 - Ajuste do eixo das abcissas.

Para finalizar, devem-se transladar horizontalmente as retas obtidas, com a finalidade de que uma reta esteja na sequência da outra. Para esta translação horizontal em eixo logarítmico foi utilizado um artificio matemático através da Equação 3.1. Nesta equação utiliza-se um fator de translação que apresenta dependência com a temperatura (Farrag (1998)), e deve ser ajustado para refinamento dos encaixes entre as retas.

$$
P_{T X}=10^{\left(\operatorname{LOG}_{(P t(x))}-\operatorname{LOG}_{(P t(x-1))}+\operatorname{LOG}_{(P T(x-1))}+L O G_{(F t)}\right)}
$$

Sendo:

$\mathrm{P}_{\mathrm{Tx}}=$ Translação horizontal para a leitura requerida;

$\mathrm{P}_{\mathrm{tx}}=$ Tempo virtual da leitura requerida;

$\mathrm{P}_{\mathrm{t}(\mathrm{x}-1)}=$ Tempo virtual da leitura anterior à requerida;

$\mathrm{P}_{\mathrm{T}(\mathrm{x}-1)}=$ Tempo obtido na translação horizontal a leitura anterior a requerida;

$\mathrm{F}_{\mathrm{t}}=$ Fator de translação. 
E, para finalizar, deve-se executar uma translação vertical para excluir a deformação nos incrementos de aumento de temperatura. A Figura 3-9 mostra a curva final de fluência obtida com os passos anteriormente citados.

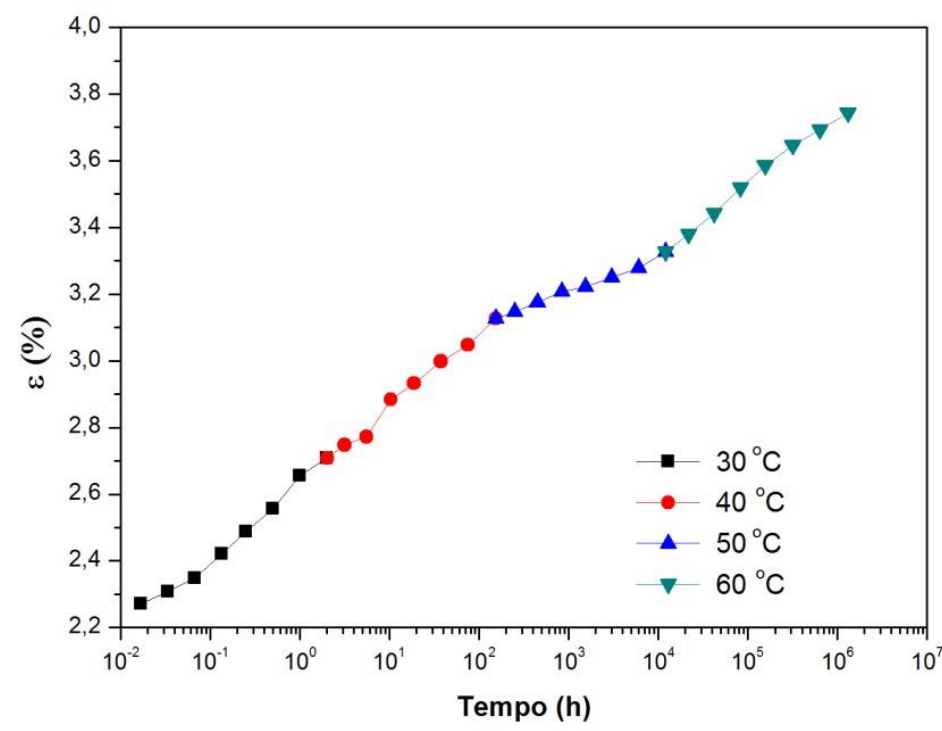

Figura 3-9 - Curva final de fluência. 


\section{RESULTADOS E ANÁLISE}

Este capítulo apresenta três partes distintas. Inicialmente são apresentados os resultados experimentais de fluência obtidos através dos ensaios anteriormente citados, e das análises realizadas nas curvas de fluência. A partir da realização dos ensaios acelerados, foi possível obter a resposta da fluência para alcance de longos tempos. $\mathrm{Na}$ sequência é realizada uma breve análise do comportamento do geotêxtil em relação as suas deformações lineares no estado limite de serviço, comparando a fluência métrica com a carga e o tempo de vida útil do material.

\subsection{GEOTÊXTIL DE FILAMENTO CONTÍNUO}

Para este material, realizou-se um total de quatorze ensaios convencionais e vinte ensaios acelerados (SIM), divididos em cinco diferentes tipos de carregamento. As curvas obtidas representam a deformação por fluência em função do tempo. Estas curvas estão separadas e exibidas em função do carregamento imposto sobre o material.

Primeiramente são apresentados os ensaios convencionais, seguidos dos ensaios acelerados pelo método Stepped Isothermal Method (SIM) e para finalizar são apresentadas as curvas finais de deformação por fluência.

A Figura 4-1 ilustra as três etapas agora citadas, ela se refere aos resultados encontrados para um carregamento de $5 \%$ do carregamento médio máximo correspondente a $14,9 \mathrm{~kg}$. 
a)

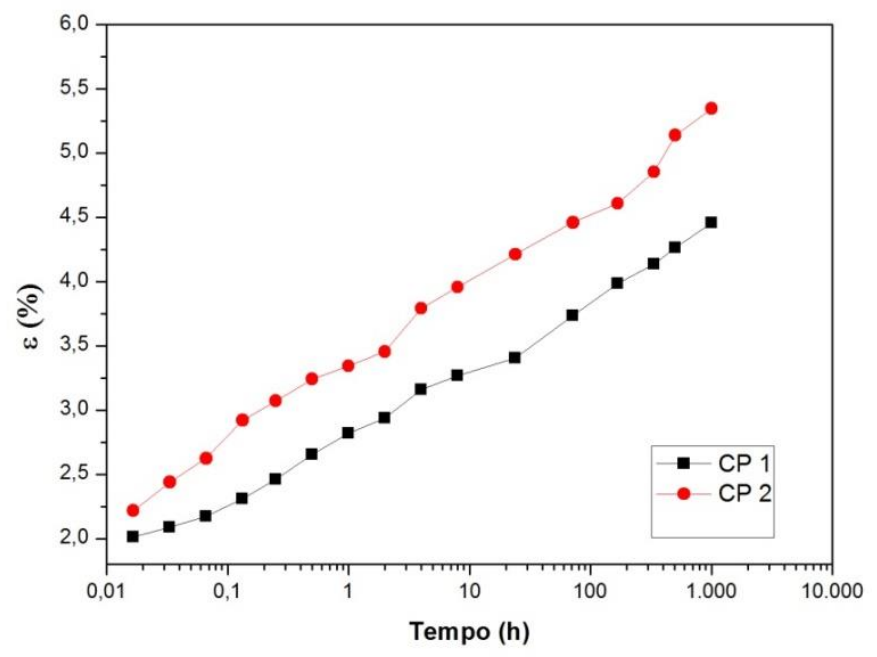

b)

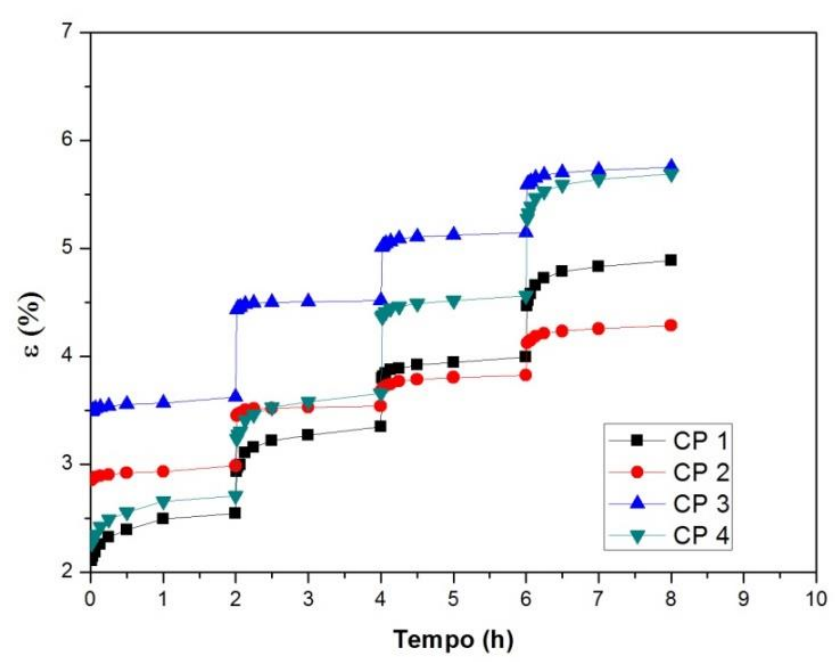

c)

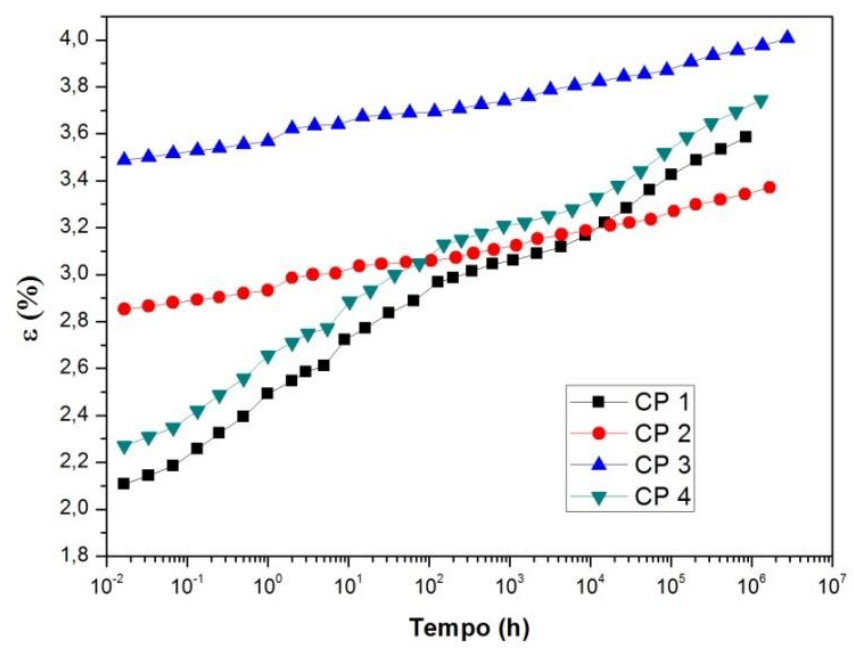

Figura 4-1 - GTnwL - 5\%, a) Ensaio Convencional, b) SIM - Tempo Virtual, SIM - Curva Final. 
A variação da deformação inicial do geotêxtil para esta carga apresenta valores entre $2 \%$ e $3,5 \%$ do inicial. Para os dois ensaios convencionais esta deformação apresenta menor variabilidade se comparada ao ensaio SIM. Quando a análise ocorre com os dois tipos de ensaios é perceptível que a variação da deformação inicial varia pouco entre os diferentes tipos de ensaio.

Os alcances das curvas de fluência para o ensaio acelerado apresentaram resultados considerados homogêneos se comparados com resultados de outros estudos. As curvas obtiveram um alcance de no mínimo 97 anos e chegaram a um máximo de 314 anos.

Já a Figura 4-2 demonstra os resultados obtidos para uma carga de 10\% do carregamento médio máximo correspondente a $29,8 \mathrm{~kg}$.

Para os ensaios com carga de 29,8 kg (10\% do carregamento), as deformações iniciais sofridas pelo corpo de prova são da ordem de 5,3\% a 7,3\%, demonstrando que os valores entre ensaios convencionais e acelerados são próximos. Estas deformações estão aproximadamente igual ao dobro das observadas nos ensaios de carregamento de $14,9 \mathrm{~kg}$ (metade da carga aplicada nesta etapa). As curvas tiveram um alcance entre 23 anos e 64 anos.

A Figura 4-3 mostra as etapas de ensaios, ela se refere aos resultados encontrados para um carregamento de $20 \%$ correspondente a $59,6 \mathrm{~kg}$. 
a)

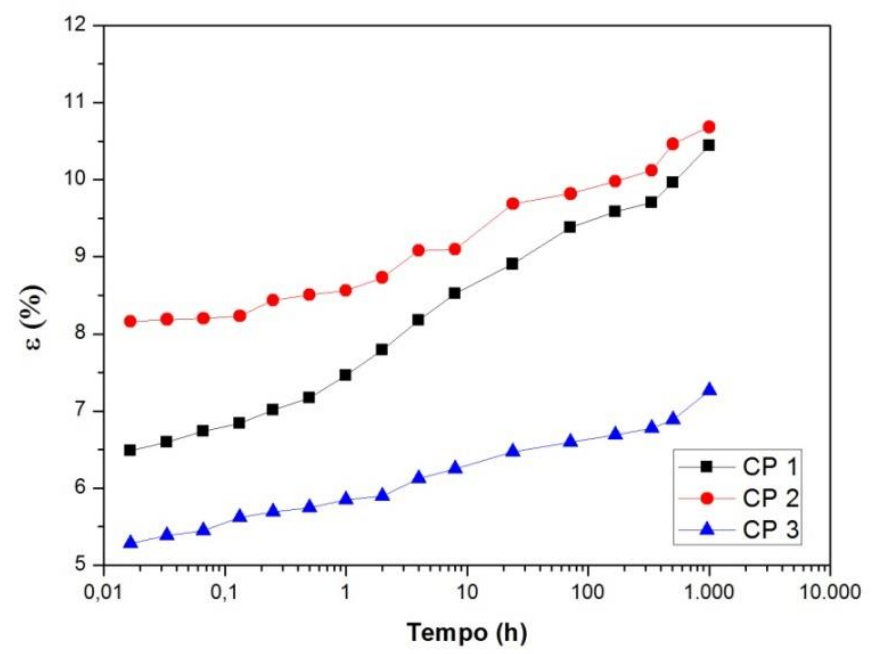

b)

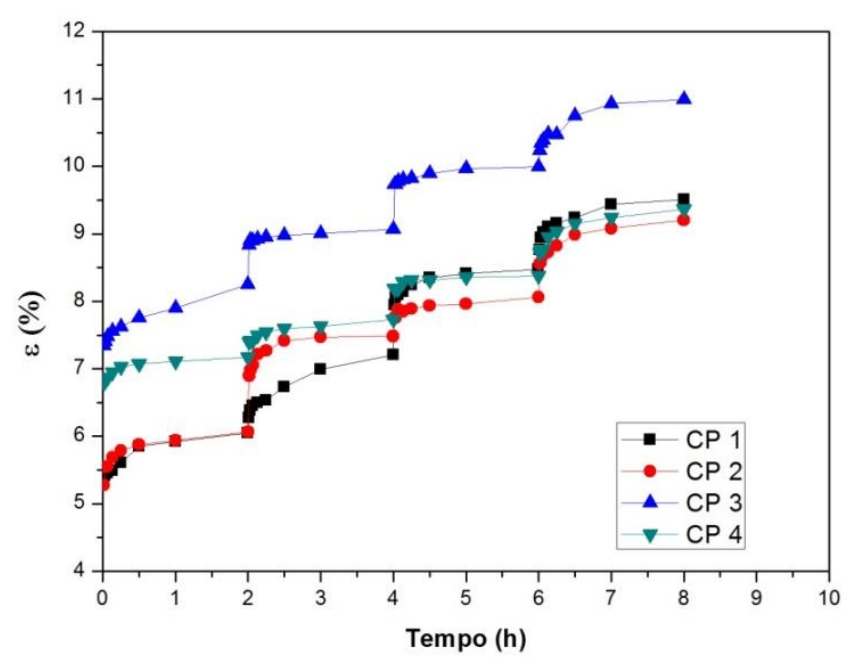

c)

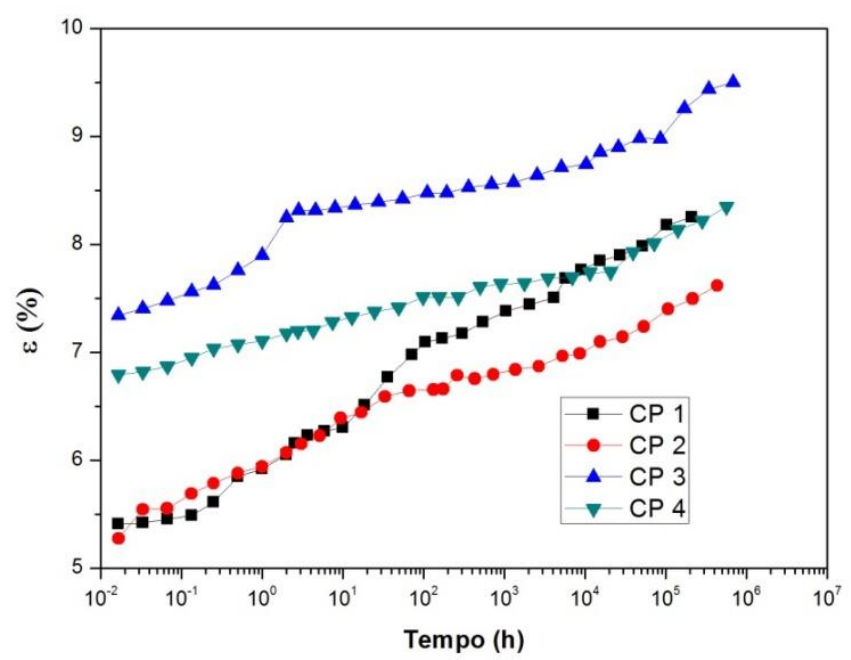

Figura 4-2 - GTnwL - 10\%, a) Ensaio Convencional, b) SIM - Tempo Virtual, SIM - Curva Final. 
a)

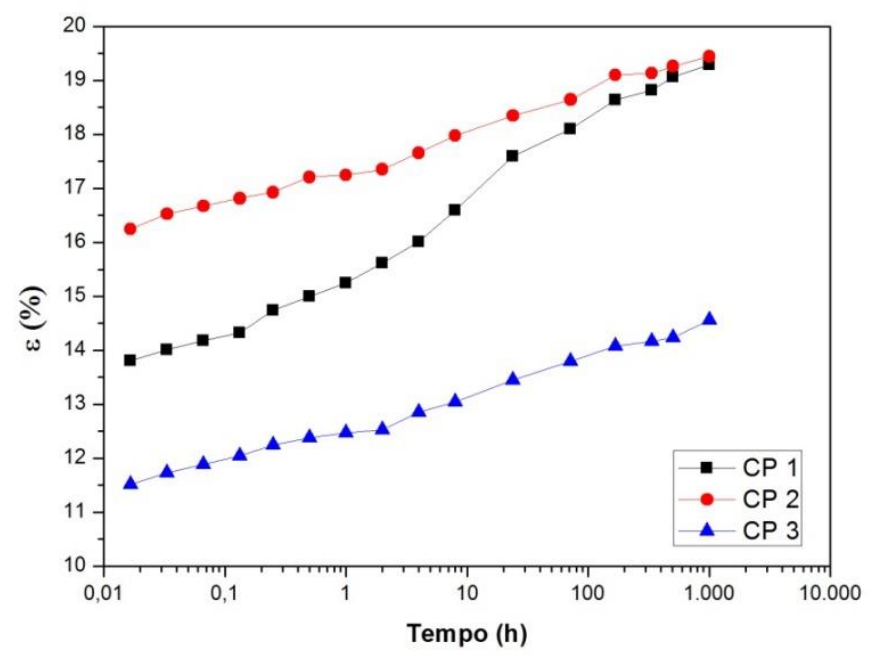

b)

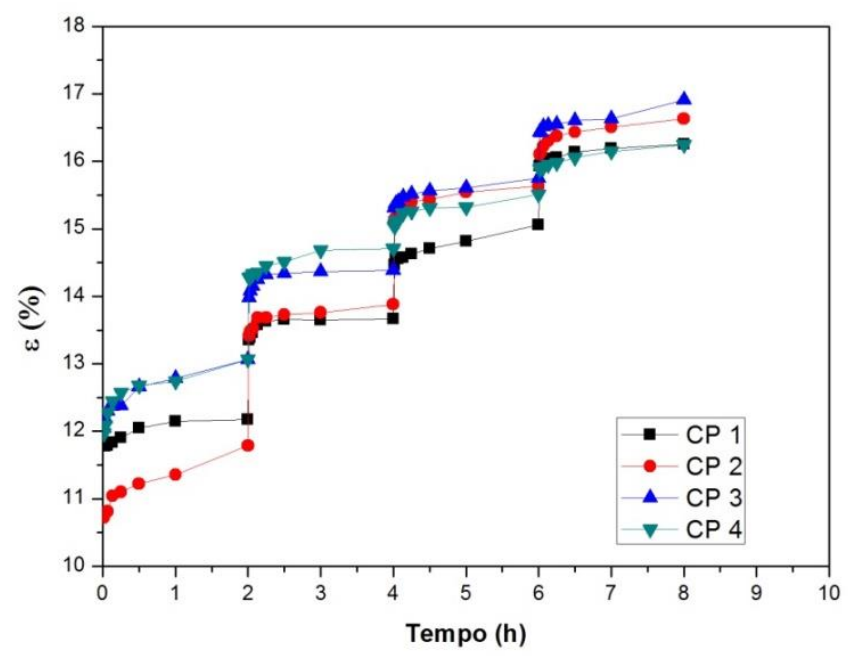

c)

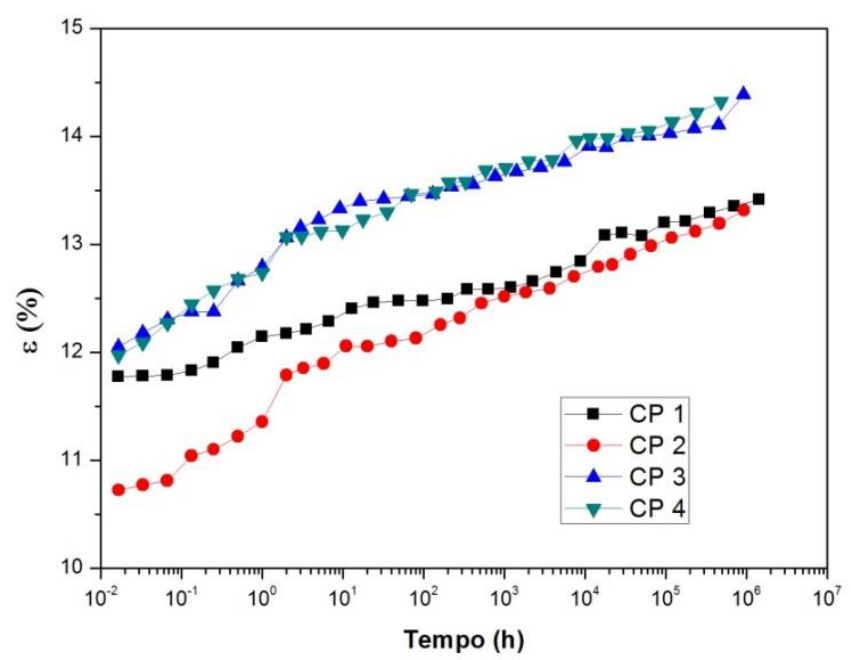

Figura 4-3 - GTnwL - 20\%, a) Ensaio Convencional, b) SIM - Tempo Virtual, SIM - Curva Final. 
A deformação inicial observada para os ensaios convencionais de $20 \%$ da carga de ruptura apresenta-se dentro de um intervalo de $11 \%$ a $16 \%$ de alteração do tamanho do geotêxtil. Quando comparamos os ensaios acelerados, os valores obtidos ficam abaixo dos valores convencionais, e as deformações iniciais observadas compreendem um intervalo menor e mais homogêneo de amplitude entre 10,7\% e 12\%. O fenômeno da fluência é perceptivelmente mais intenso do que os comparados em ensaios com cargas inferiores. Tais curvas finais descreveram um alcance entre 55 e 163 anos para os resultados de ensaio SIM.

Foram realizados quatro ensaios acelerados e três ensaios convencionais para a carga de $40 \%$ da resistência total a tração (ou 119,2 kg). A Figura 4-4 demonstra os resultados encontrados. O primeiro e segundo ensaios convencionais demonstraram uma deformação instantânea da ordem de $25 \%$ de alteração, já o terceiro ensaio realizado apontou uma deformação por fluência com amplitude menor que os anteriores e com valor de 17\%. Quando analisados as deformações instantâneas do ensaio acelerado, nota-se que os resultados variam entre $17 \%$ e $23 \%$, abrangendo a mesma faixa de variação resultante dos convencionais.

As curvas convencionais, quando comparadas com as obtidas pelo ensaio SIM, apresentam uma maior influência do fenômeno da fluência, isto porque, os ensaios acelerados demonstraram uma inclinação mais acentuada em seus resultados. $\mathrm{O}$ alcance das curvas de fluência pelo método de Thornton (1998) variou entre 60 e 166 anos.

Por fim, realizaram-se ensaios com $60 \%$ de carga máxima, perfazendo um carregamento total de $178,8 \mathrm{~kg}$. As deformações iniciais estão na Figura 4-5 e variaram entre $29 \%$ e $38 \%$ para os ensaios convencionais. Já os ensaios acelerados apresentaram deformações instantâneas na ordem de $27 \%$ a $32 \%$, demonstrando deformações iniciais semelhantes com a faixa de variação menor que $10 \%$ entre as máximas e mínimas deformações por fluência.

O alcance das curvas de fluência pelo método idealizado por Thornton (1998) foi de 24 a 168 anos. 
a)

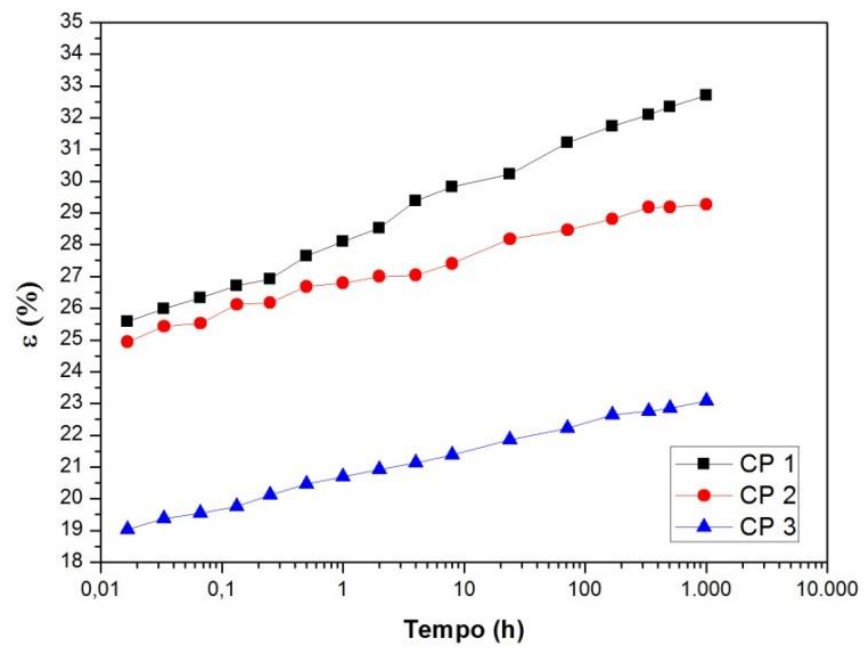

b)

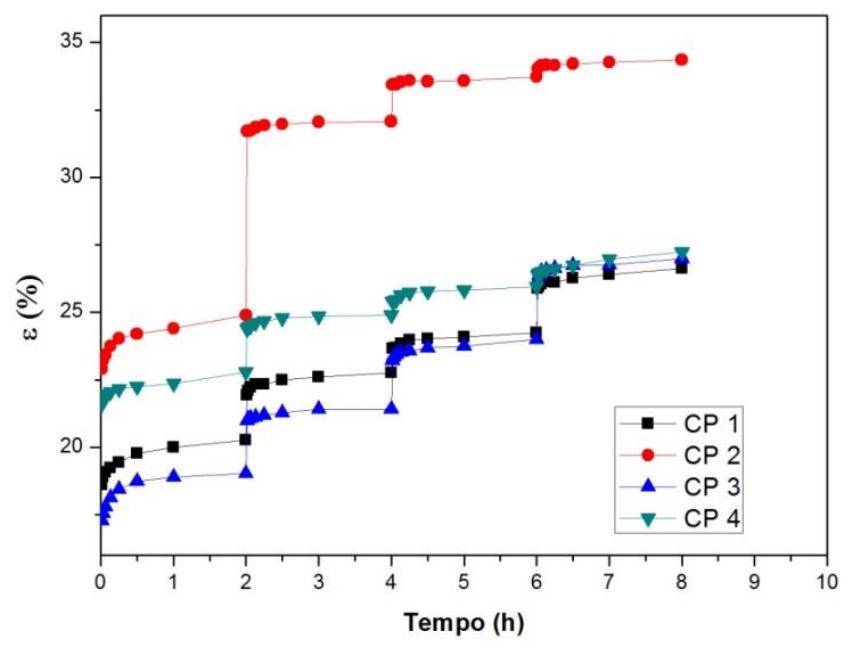

c)

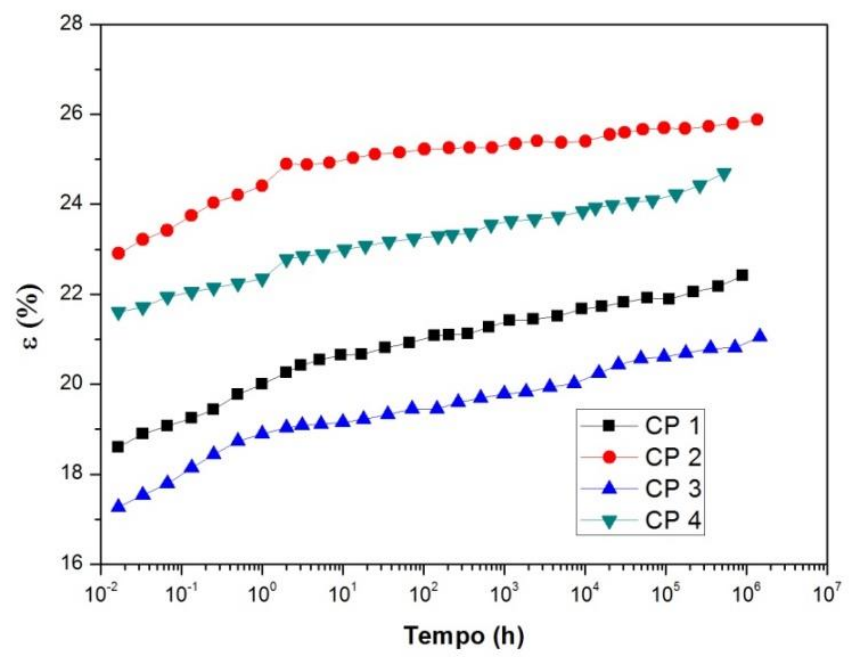

Figura 4-4 - GTnwL - 40\%, a) Ensaio Convencional, b) SIM - Tempo Virtual, SIM - Curva Final. 
a)

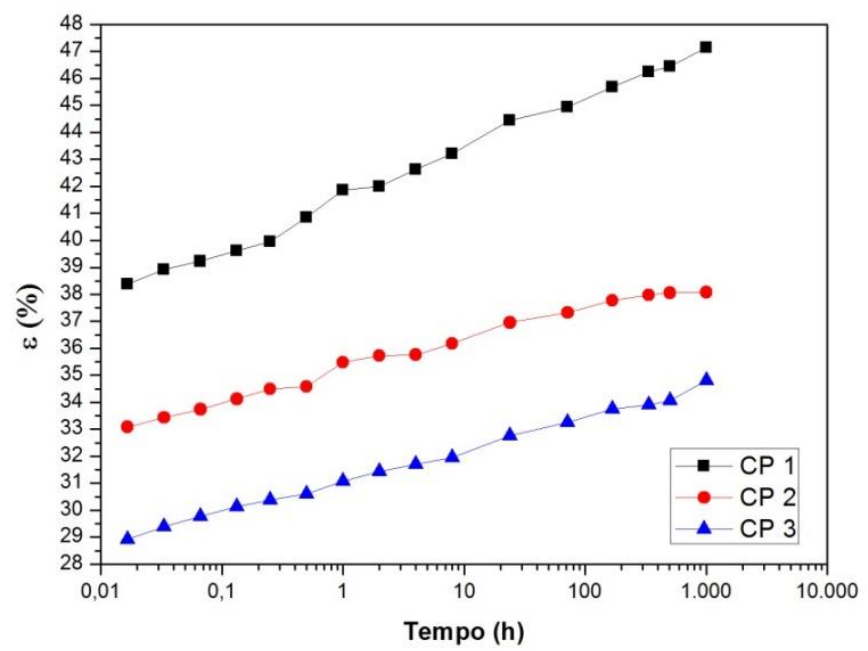

b)

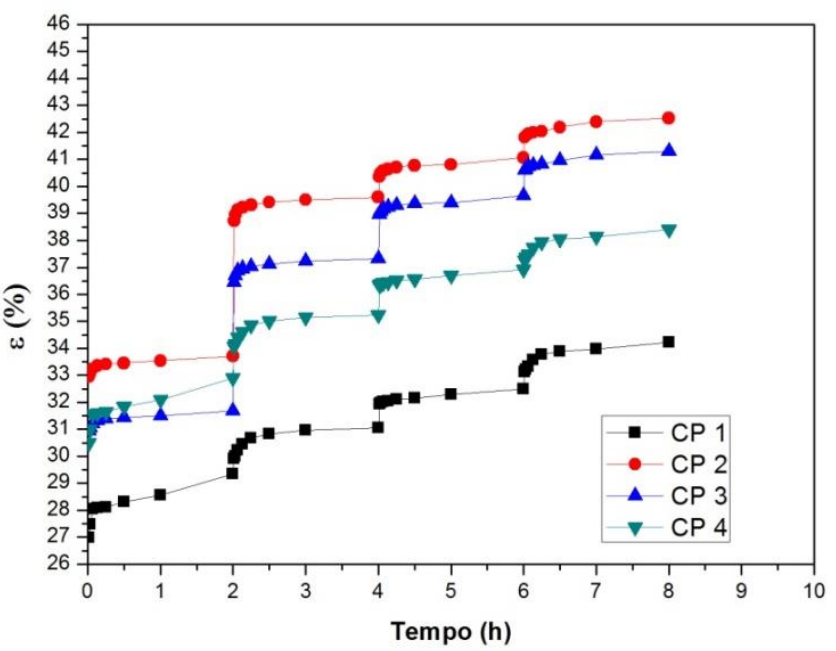

c)

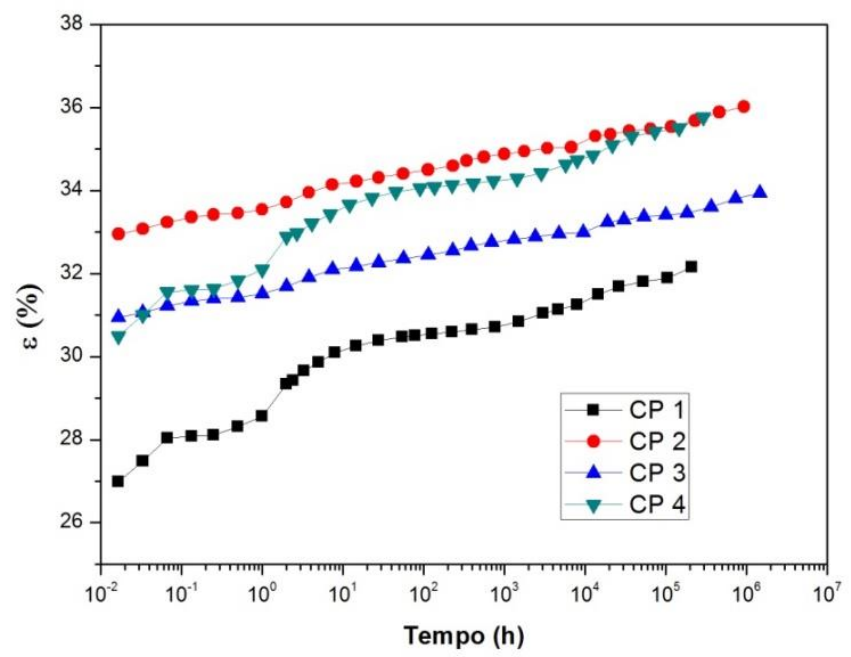

Figura 4-5 - GTnwL - 60\%, a) Ensaio Convencional, b) SIM - Tempo Virtual, SIM - Curva Final. 
Baras (2001) realizou ensaios para este mesmo tipo de material, com a característica de filamentos contínuos. Para os ensaios convencionais ele encontrou deformações iniciais de $10 \%$ para o carregamento do geotêxtil com 10\%, deformação de $19 \%$ para um carregamento de $20 \%$, deformação de $27 \%$ para um carregamento de $40 \%$ e deformação de $43 \%$ para um carregamento de $60 \%$ da carga máxima. Da mesma forma, para o ensaio acelerado, os valores iniciais encontrados para os carregamentos de $10,20,40$ e $60 \%$ foram respectivamente $12,16,31$ e $47 \%$.

Ao comparar os resultados encontrados por Baras (2001) com os obtidos neste estudo, verifica-se que o produto demonstra uma resistência maior quanto à deformação inicial, pois os valores encontrados são sempre menores que os valores explicitados pelo trabalho de Baras (2001).

O tempo de resposta, das curvas de fluência dos ensaios acelerados após as transformações e translações efetuadas, perfez um alcance mínimo de 16 horas e um máximo de 2,4 anos. Este resultado mostra um alcance muito inferior aos encontrados nesta pesquisa, isto pode ser creditado a uma escolha deficitária na inclinação da reta, ou mesmo no tempo virtual de início de cada etapa, o que prejudica um alcance maior das curvas.

A Tabela 4-1 resume os valores e coeficientes das curvas encontradas através dos ensaios acelerados. 
Tabela 4-1 - Coeficientes das curvas pelo método SIM do GTnwL.

\begin{tabular}{c|c|c|c|c|c|c}
\hline $\begin{array}{c}\text { Carregamento } \\
(\%)\end{array}$ & Y & a LOG(t) & $\mathbf{b}$ & $\mathbf{R}^{2}$ & $\begin{array}{c}\text { Alcance } \\
\text { (anos) }\end{array}$ & $\begin{array}{c}\text { Peso CP } \\
\text { (gramas) }\end{array}$ \\
\hline \multirow{3}{*}{5} & 1 SIM & 0,082 & 2,480 & 0,987 & 97 & 23,37 \\
& 2 SIM & 0,027 & 2,948 & 0,990 & 192 & 28,30 \\
& 3 SIM & 0,026 & 3,582 & 0,990 & 314 & 26,51 \\
& 4 SIM & 0,080 & 2,639 & 0,987 & 148 & 23,38 \\
\hline \multirow{3}{*}{10} & 1 SIM & 0,190 & 6,003 & 0,988 & 24 & 28,75 \\
& 2 SIM & 0,123 & 5,980 & 0,981 & 49 & 28,43 \\
& 3 SIM & 0,105 & 7,926 & 0,931 & 78 & 28,93 \\
& 4 SIM & 0,080 & 7,103 & 0,974 & 64 & 29,53 \\
\hline \multirow{3}{*}{20} & 1 SIM & 0,092 & 12,080 & 0,981 & 163 & 26,74 \\
& 2 SIM & 0,142 & 11,463 & 0,966 & 106 & 26,71 \\
& 3 SIM & 0,116 & 12,812 & 0,934 & 104 & 27,77 \\
& 4 SIM & 0,127 & 12,780 & 0,964 & 55 & 26,85 \\
\hline \multirow{3}{*}{40} & 1 SIM & 0,193 & 19,920 & 0,953 & 103 & 28,57 \\
& 2 SIM & 0,132 & 24,311 & 0,824 & 156 & 28,29 \\
& 3 SIM & 0,176 & 18,600 & 0,953 & 166 & 30,37 \\
& 4 SIM & 0,159 & 22,458 & 0,978 & 60 & 31,25 \\
\hline \multirow{3}{*}{60} & 1 SIM & 0,285 & 28,920 & 0,934 & 24 & 28,43 \\
& 2 SIM & 0,169 & 33,670 & 0,995 & 106 & 29,20 \\
& 3 SIM & 0,159 & 31,642 & 0,994 & 168 & 27,90 \\
& 4 SIM & 0,281 & 32,405 & 0,941 & 33 & 28,00 \\
\hline & & & & & & \\
\hline
\end{tabular}

\subsection{GEOTÊXTIL DE FIBRA CURTA}

Analogamente ao outro material, para o geotêxtil de fibra curta foi realizado a mesma quantidade de ensaios, sendo quatorze ensaios convencional e vinte ensaios acelerados (SIM), os níveis de carregamento estabelecidos foram porcentagens da resistência máxima à tração do produto e apresentam os mesmos critérios utilizados para o geotêxtil de filamento contínuo. As curvas obtidas foram separadas e exibidas em função do carregamento imposto sobre o material.

A Figura 4-6 ilustra as etapas para o carregamento de 5\% do carregamento médio máximo correspondente a $12,5 \mathrm{~kg}$.

Para o carregamento de 5\%, o geotêxtil de fibra curta apresentou uma variação instantânea de 3,5\% a 4\% do tamanho inicial. Para os dois ensaios convencionais esta 
deformação apresenta menor variabilidade se comparada ao ensaio SIM, que apresentou deformações da ordem de $4 \%$ a 6,3\%. Quando a análise ocorre entre os dois tipos de geotêxteis é perceptível que a deformação inicial é maior para o elemento de fibra curta.

As curvas de fluência, pelo método acelerado, obtiveram um alcance de no mínimo 9 anos e alcançaram um máximo de 210 anos, demonstrando uma variação entre tempos relativamente semelhante a variação para o produto anterior.

Já a Figura 4-7 apresenta os resultados obtidos para uma carga de 10\% do carregamento médio máximo correspondente a $25,0 \mathrm{~kg}$. 
a)

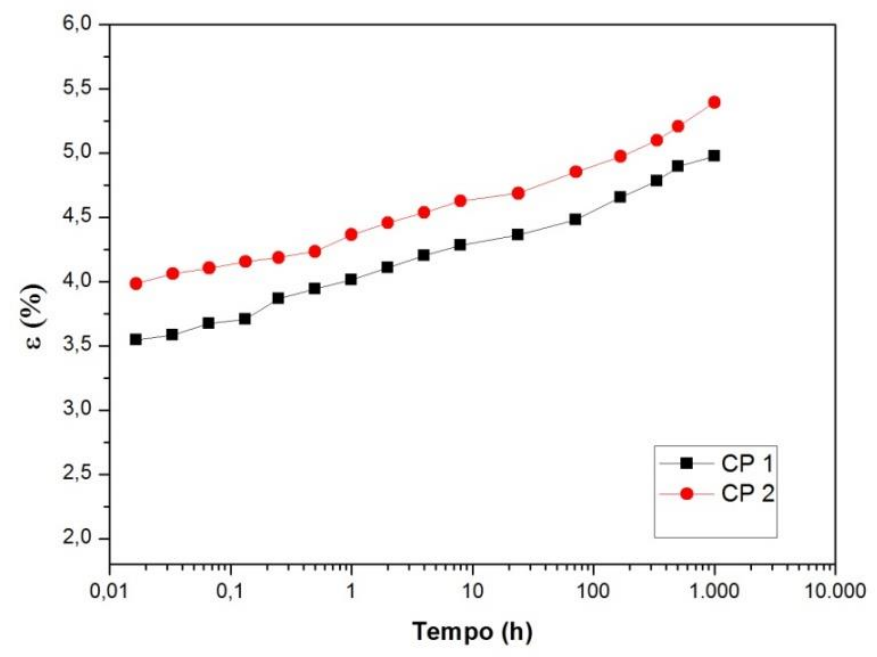

b)

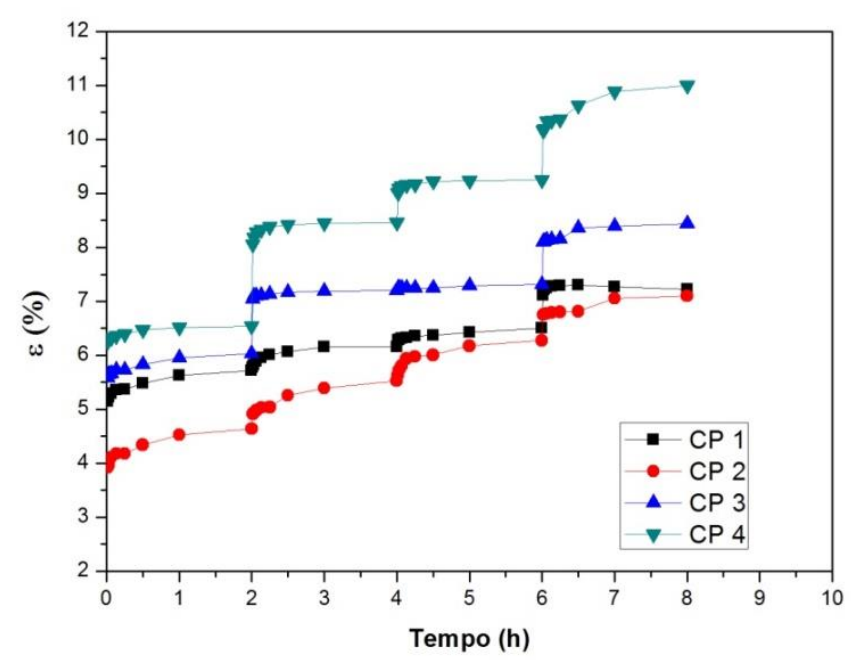

c)

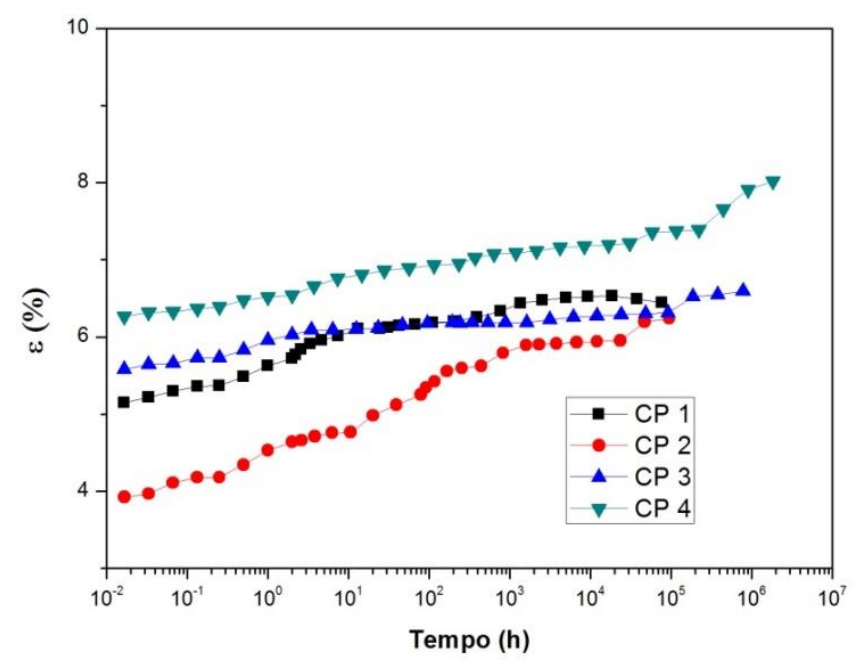

Figura 4-6 - GTnwS - 50\%, a) Ensaio Convencional, b) SIM - Tempo Virtual, SIM - Curva Final. 
a)

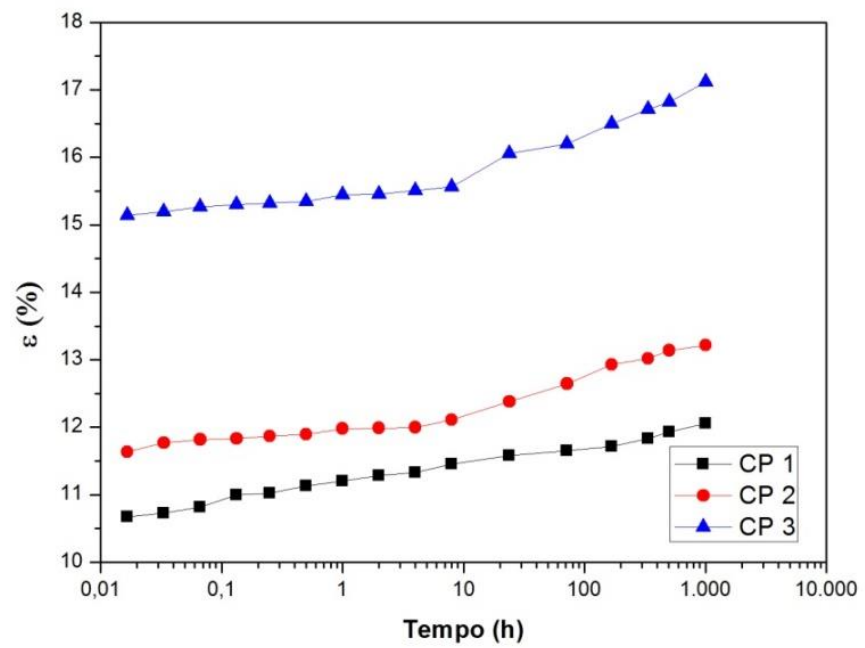

b)

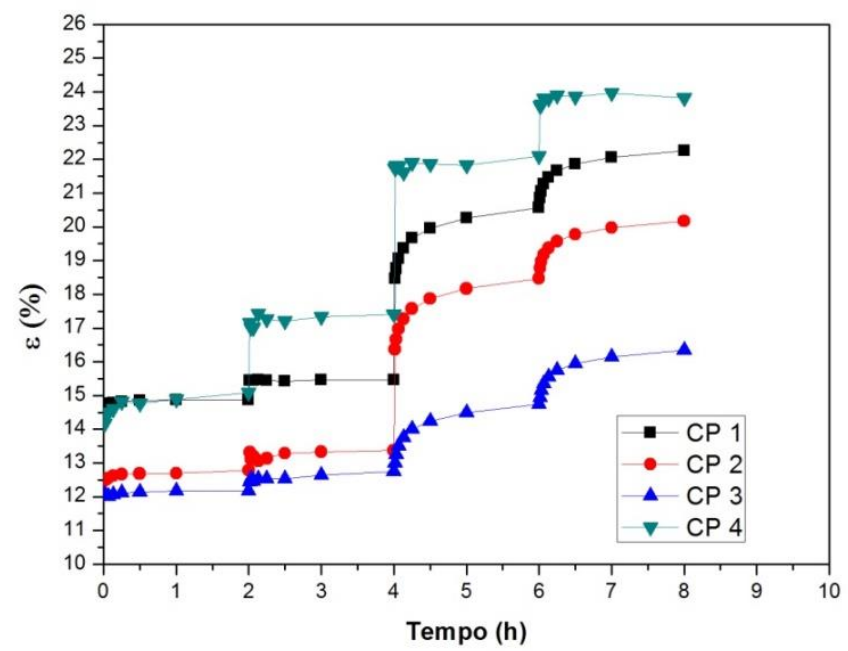

c)

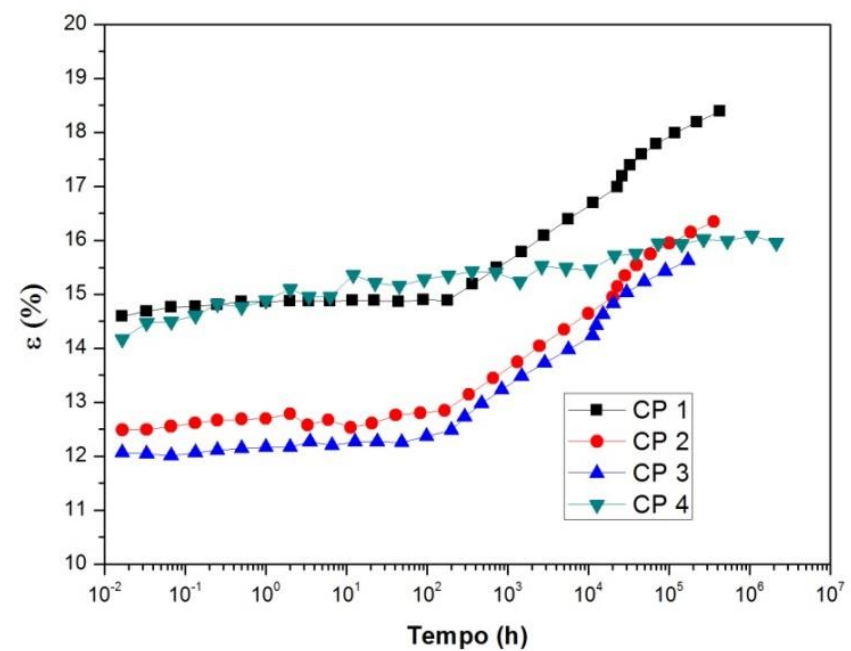

Figura 4-7 - GTnwS - 10\%, a) Ensaio Convencional, b) SIM - Tempo Virtual, SIM - Curva Final. 
Para esta carga, os ensaios convencionais apresentaram deformações iniciais sofridas pelo corpo de prova na ordem de $10,7 \%$ a $15,1 \%$, e nos ensaios acelerados com $12,1 \%$ e $14,6 \%$. Os valores obtidos para os ensaios acelerados estão compreendidos na faixa de variação do ensaio convencional, e denotam uma amplitude de 4,4\% entre o mínimo e o máximo observado.

As curvas tiveram um tempo de alcance entre 48 anos e 243 anos, com intervalo de 195 anos entre o máximo e o mínimo, intervalo este muito parecido com o encontrado para o carregamento de 5\% do mesmo material. Para os ensaios acelerados com o carregamento de $10 \%$, as curvas apresentaram uma mudança de inclinação entre a segunda e terceira etapa de aquecimento. Tal fenômeno pode ser resultado da escolha do tempo virtual de início para esta etapa.

A Figura 4-8 se refere aos resultados encontrados para um carregamento de $20 \%$ correspondente a $50,0 \mathrm{~kg}$.

A deformação inicial observada para os ensaios convencionais com $20 \%$ da carga de ruptura apresenta-se dentro de um intervalo de 20,7\% a 21,6\%. Quando comparamos os ensaios acelerados, os valores obtidos ficam próximos dos valores convencionais para os três primeiros ensaios realizados, e as deformações iniciais observadas compreendem um intervalo de amplitude entre $21,2 \%$ e $22,4 \%$.

Já o quarto ensaio acelerado apresentou um resultado inferior ao padrão observado, e sua deformação foi de 17,6\%, este fenômeno observado pode ser explicado pela variabilidade física do material, que apresentou um corpo de prova com massa por unidade de área superior aos outros CPs. As curvas finais descreveram um alcance de 12 a 355 anos para os resultados de ensaio SIM, demonstrando uma amplitude maior que as observadas para o mesmo material com cargas inferiores, e uma grande heterogeneidade dos tempo de alcance se comparados com o produto de filamento contínuo.

Os resultados para a carga de $40 \%$ da resistência total a tração (ou 100,0 kg) estão na Figura 4-9. 
a)

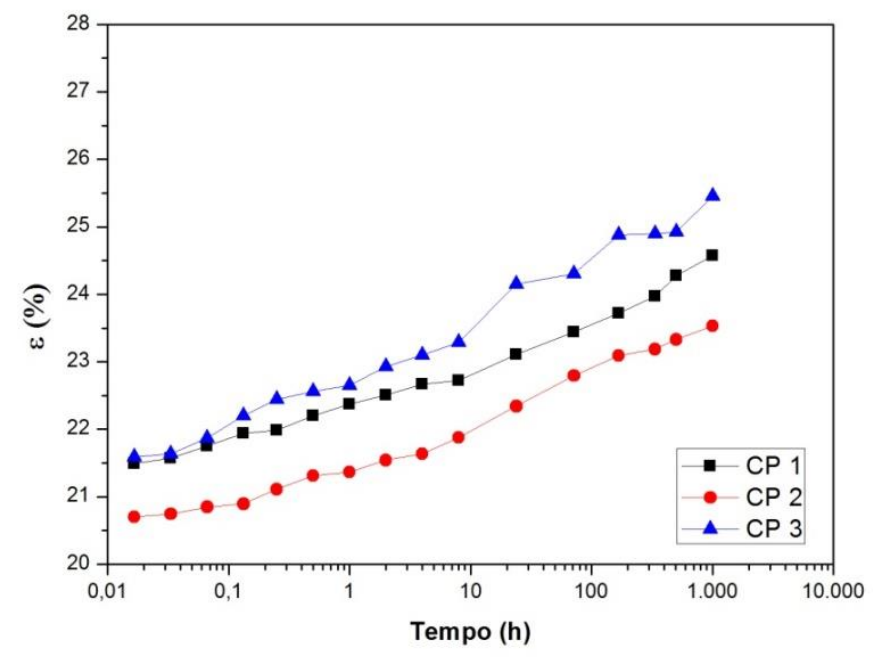

b)

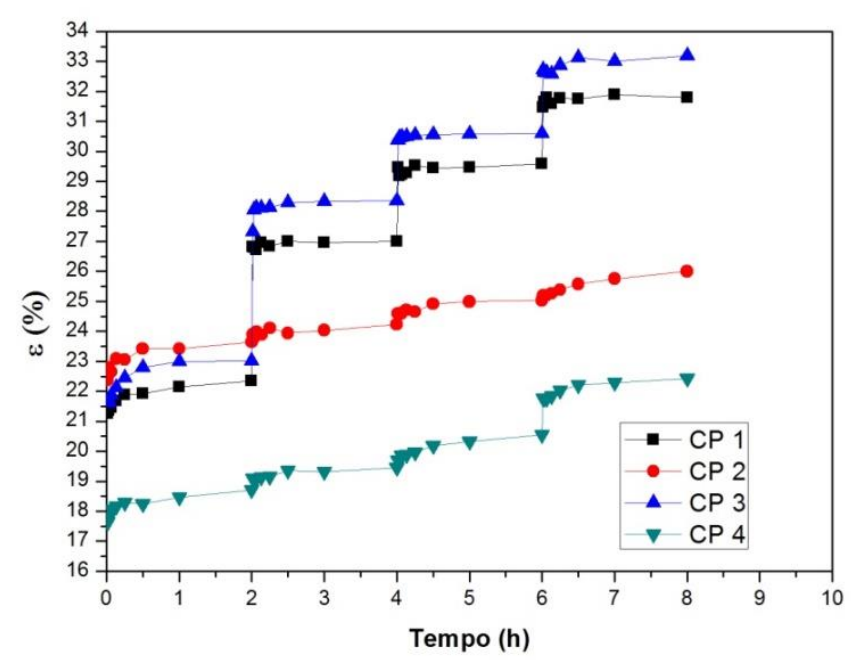

c)

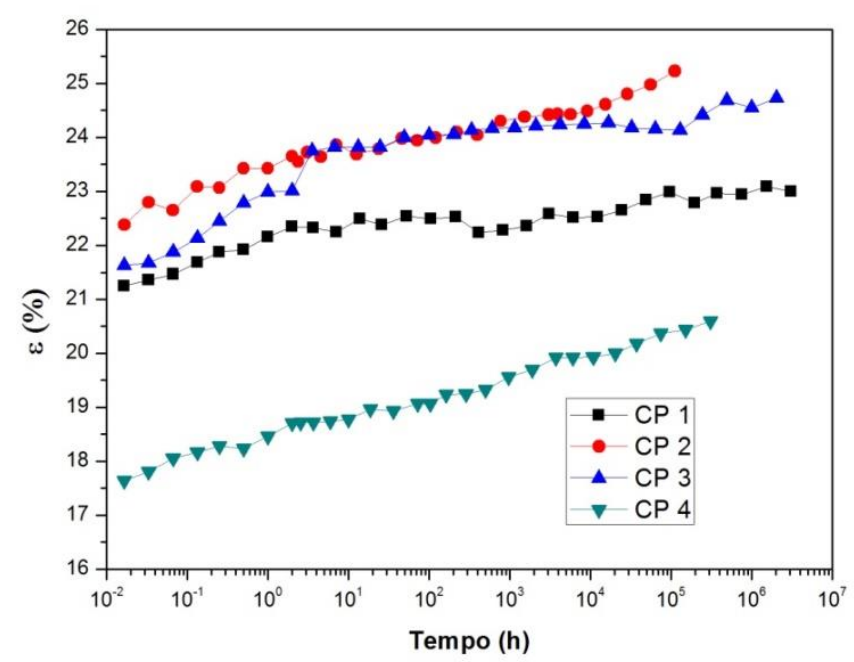

Figura 4-8 - GTnwS - 20\%, a) Ensaio Convencional, b) SIM - Tempo Virtual, SIM - Curva Final. 
a)

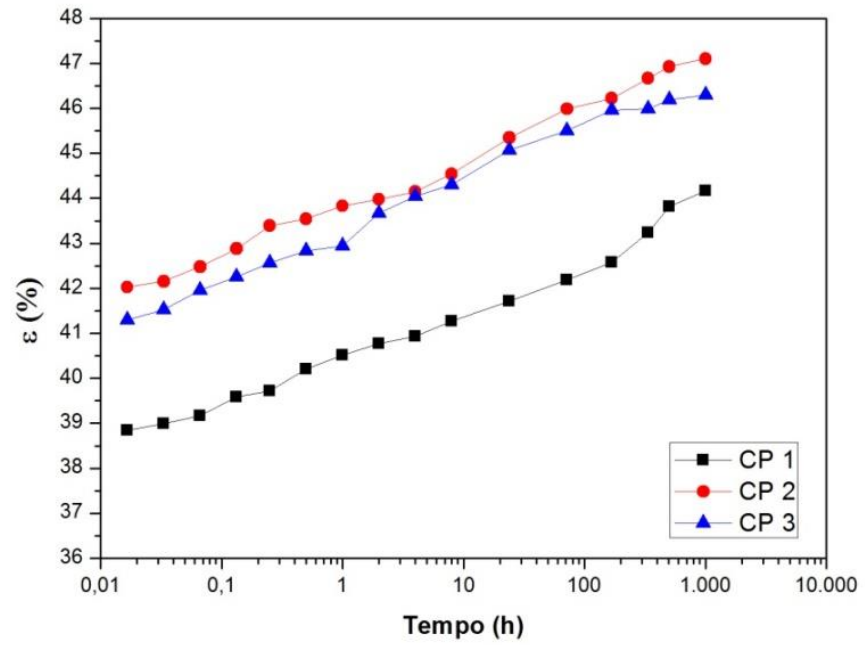

b)

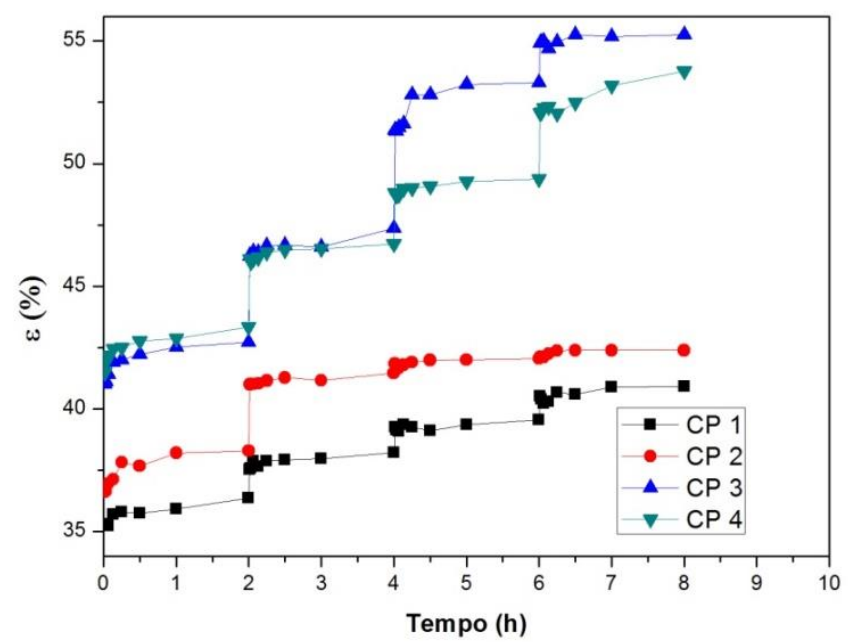

c)

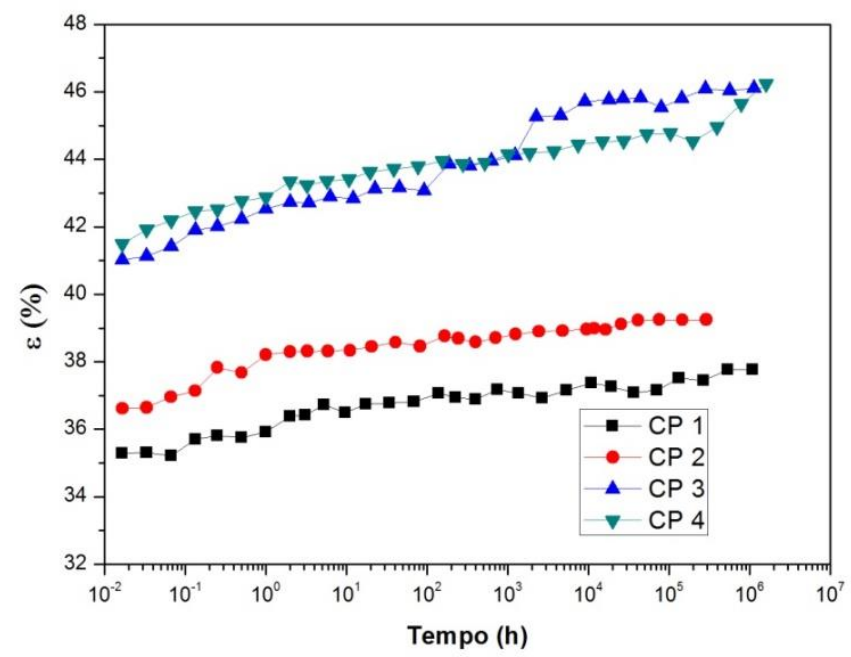

Figura 4-9 - GTnwS - 40\%, a) Ensaio Convencional, b) SIM - Tempo Virtual, SIM - Curva Final. 
As amplitudes de deformação inicial registradas para os ensaios convencionais compreendem um intervalo entre $38,8 \%$ e $42 \%$. Quando analisados as deformações instantâneas do ensaio acelerado, nota-se que os resultados variam entre 35,3\% e 41,5\%, abrangendo uma faixa de variação semelhante a denotada pelos convencionais.

Os resultados obtidos, para o elemento de fibra curta, apresentam deformações superiores quando comparados com os valores de mesmo carregamento para o produto de filamento continuo. Algumas destas chegam a ter ordem de superioridade em mais de 100 por cento de deformidade, ilustrando uma variabilidade entre produtos a partir de diferentes materiais (tipo de fibra). $\mathrm{O}$ alcance das curvas de fluência pelo método acelerado (Thornton 1998) variou entre 33 e 181 anos.

Os últimos ensaios efetuados foram com $60 \%$ de carga máxima, aonde o carregamento total imposto ao material foi de 150,0 kg (Figura 4-10). As deformações iniciais variaram entre $44,9 \%$ e $56,1 \%$ para os ensaios convencionais. Já os ensaios acelerados apresentaram deformações instantâneas na ordem de 47,7\% a 52,8\%, demonstrando um intervalo de $11,2 \%$ de fluência entre o máximo e mínimo encontrado para todos os ensaios. O alcance das curvas de fluência através do método idealizado por Thornthon foi de 162 a 250 anos. 
a)

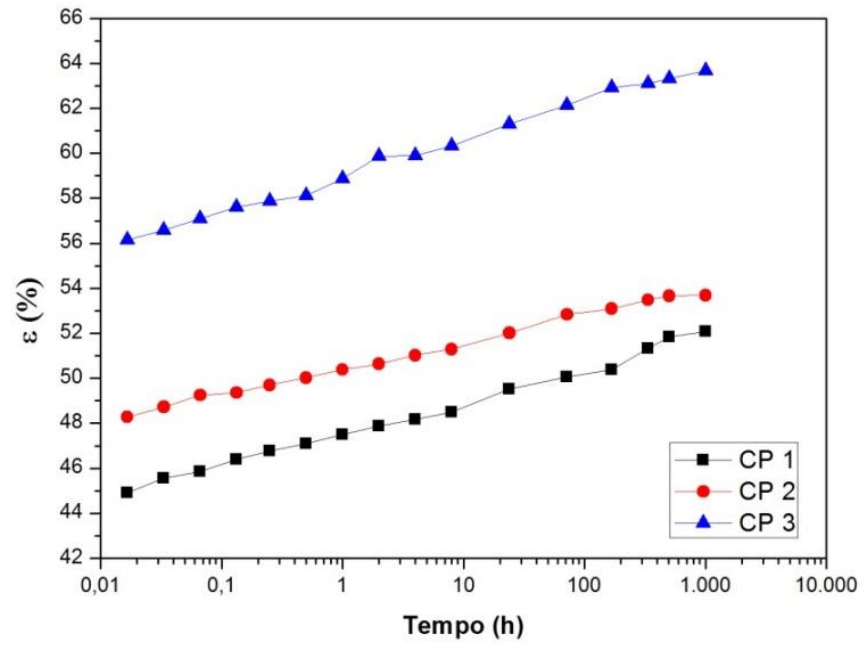

b)

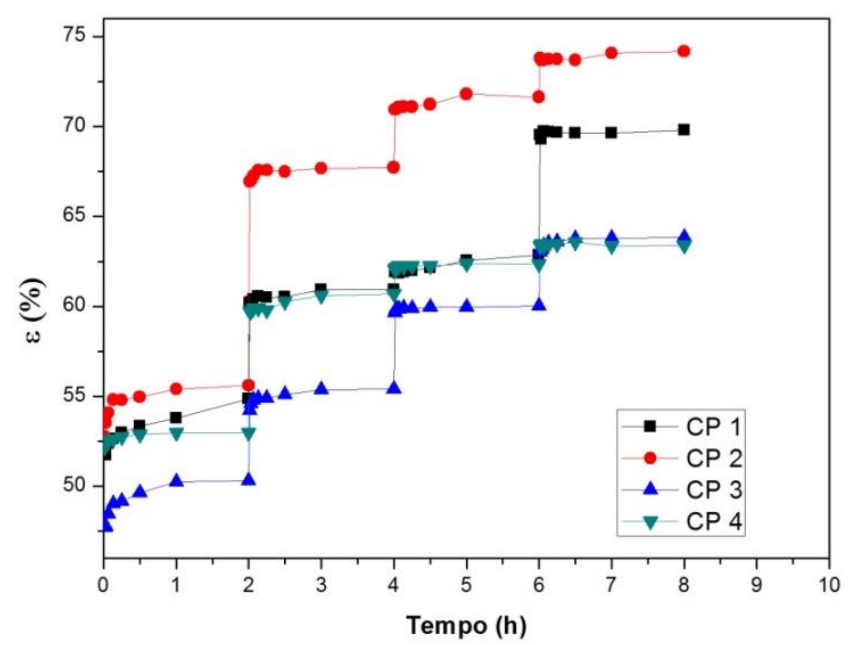

c)

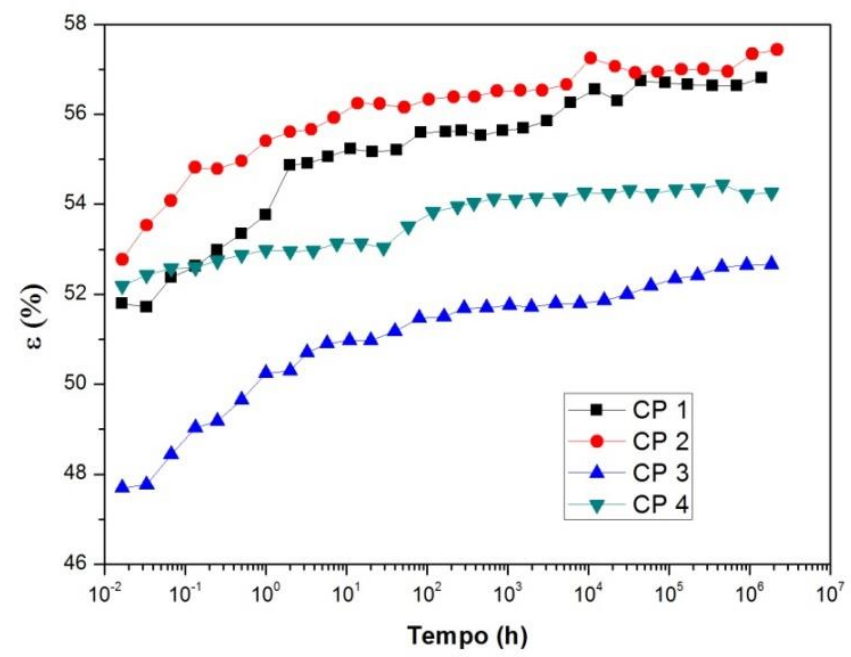

Figura 4-10 - GTnwS - 60\%, a) Ensaio Convencional, b) SIM - Tempo Virtual, SIM - Curva Final. 
O material de fibra curta, e mesma massa por unidade de área, foi anteriormente ensaiado por Costanzi (2003), o qual realizou estudos sobre o comportamento da fluência para este produto. Os alcances das curvas finais de fluência obtidos por este autor demonstraram uma grande variabilidade se comparada com os resultados encontrados neste estudo. Costanzi (2003) encontrou alcances de tempo que perfaziam um intervalo de 4 a 3649 anos para o geotêxtil de fibra curta, já a variação constatada nesta pesquisa compõe um intervalo de 9 a 355 anos. Esta menor variabilidade tem influencia direta da escolha da inclinação da curva ao encontrar o tempo virtual. É notório que os alcances ficam próximos a 100 anos, tempo este citado por Thornton (1998) como sendo um alcance satisfatório para um ensaio realizado com temperaturas e etapas de tempo adequadas.

A Tabela 4-2 resume os valores e coeficientes das curvas encontradas através dos ensaios acelerados, para o geotêxtil de fibra curta.

Tabela 4-2 - Coeficientes das curvas pelo método SIM, fibra curta.

\begin{tabular}{c|c|c|c|c|c|c}
\hline $\begin{array}{c}\text { Carregamento } \\
(\%)\end{array}$ & Y & a LOG(t) & $\mathbf{b}$ & $\mathbf{R}^{2}$ & $\begin{array}{c}\text { Alcance } \\
\text { (anos) }\end{array}$ & $\begin{array}{c}\text { Peso CP } \\
\text { (gramas) }\end{array}$ \\
\hline \multirow{3}{*}{5} & 1 SIM & 0,0962 & 5,6733 & 0,9216 & 9 & 29,81 \\
& 2 SIM & 0,1635 & 4,5336 & 0,9784 & 10 & 29,04 \\
& 3 SIM & 0,0472 & 5,8942 & 0,9028 & 89 & 29,83 \\
& 4 SIM & 0,081 & 6,5304 & 0,9503 & 210 & 31,41 \\
\hline \multirow{3}{*}{10} & 1 SIM & 0,0467 & 14,806 & 0,8537 & 48 & 30,73 \\
& 2 SIM & 0,0571 & 12,639 & 0,871 & 41 & 32,35 \\
& 3 SIM & 0,0571 & 12,144 & 0.7987 & 19 & 34,80 \\
& 4 SIM & 0,0876 & 14,841 & 0,9374 & 243 & 30,31 \\
\hline \multirow{4}{*}{20} & 1 SIM & 0,0759 & 21,975 & 0,8237 & 355 & 34,59 \\
& 2 SIM & 0,1434 & 23,343 & 0,9506 & 12 & 35,40 \\
& 3 SIM & 0,1462 & 22,912 & 0,7988 & 231 & 33,31 \\
& 4 SIM & 0,1657 & 18,44 & 0,9877 & 35 & 32,41 \\
\hline \multirow{3}{*}{40} & 1 SIM & 0,1291 & 36,085 & 0,8894 & 124 & 27,51 \\
& 2 SIM & 0,1386 & 37,801 & 0,8507 & 33 & 35,23 \\
& 3 SIM & 0,3057 & 42,322 & 0,9642 & 129 & 32,43 \\
& 4 SIM & 0,1875 & 42,84 & 0,9344 & 181 & 31,75 \\
\hline \multirow{3}{*}{60} & 1 SIM & 0,2627 & 53,84 & 0,8583 & 162 & 32,49 \\
& 2 SIM & 0,1858 & 55,1 & 0,8291 & 250 & 32,52 \\
& 3 SIM & 0,2354 & 49,828 & 0,8633 & 213 & 34,74 \\
& 4 SIM & 0,1238 & 52,952 & 0,9038 & 214 & 34,21 \\
\hline
\end{tabular}


Quando a comparação da fluência ocorre entre os dois diferentes tipos de fibra utilizados na fabricação dos geotêxteis ensaiados, conclui-se que assim como observado nos ensaios realizados para caracterização dos produtos, o material composto por filamentos contínuos apresenta maior resistência ao carregamento e demonstra uma deformação por fluência inferior a deformação do geotêxtil de fibra curta.

Como o geotêxtil de fibra curta apresentou menor resistência em comparação com o geotêxtil de elemento de filamento contínuo, as cargas utilizadas para os ensaios apresentaram pesos menores, mas com porcentagens iguais ao outro material. Do mesmo modo, o geotêxtil de fibra curta apresentou maiores deformações por fluência, assim como era esperado e confirmando os valores obtidos no processo de caracterização.

Quando a análise diz respeito à variabilidade quanto à deformação instantânea do material, comprova-se que o produto de fibra curta apresenta maior variabilidade da deformação inicial para todos os diferentes carregamentos, exceto o ensaio com carga de $20 \%$ da resistência máxima. Neste carregamento, a variabilidade foi maior para o elemento de filamento contínuo devido ao resultado de um ensaio convencional ter demonstrado uma variação fora do padrão observado para este geotêxtil.

\subsection{ESTADO LIMITE DE SERVIÇO}

Como qualquer material utilizado na construção civil, espera-se que o geotêxtil desempenhe uma determinada função mínima de segurança por um tempo de vida especificado em projeto. O tempo de serviço do geotêxtil em projeto pode ser definido de acordo com a finalidade da obra, do contratante, ou mesmo das limitações do produto utilizado, sendo assim, tal tempo de utilização deve ser decidido na fase de concepção do projeto básico.

Geralmente a finalidade da obra é que especifica o alcance de tempo necessário para a durabilidade de cada geossintético. Obras consideradas de curto prazo ou de uso temporário geralmente apresentam um tempo de vida menor que 25 anos, em contra 
partida, construções de uso permanente desempenham uma vida útil que podem chegar a mais de 100 anos.

O período útil da vida do geotêxtil ficará intrinsicamente relacionado com a natureza da estrutura, e seu risco ambiental envolvido. $\mathrm{Na}$ maioria dos casos, os geossintéticos desempenham uma função permanente na estrutura, auxiliando o sistema como reforço até que a resistência, da estrutura, requerida em projeto possa ser alcançada. Quanto maior é a solicitação, mais curto será o tempo de vida em serviço do geotêxtil, pois maior será o efeito da deformação imposta ao material.

O fim da vida de serviço do geossintético pode ser considerado o momento em que a propriedade funcional do material alcança a propriedade requerida de resistência média. Neste momento considera-se que o geossintético não mais desempenha sua função original.

O engenheiro deverá imputar em seus cálculos uma margem de segurança ao final da vida de serviço de projeto, de modo que a falha estrutural esteja prevista para ocorrer além do tempo de vida útil requerido pela obra.

Sendo assim, neste subcapitulo abordaremos uma análise quantitativa da fluência em termos de alongamento métrico do geotêxtil. A previsão dos valores de deformação foi realizada através das equações das curvas mestras obtidas anteriormente. Os resultados explicitados a seguir se referem a deformações previstas para até 100 anos de vida útil do material.

Para representar a amplitude a qual a deformação do geotêxtil possa atingir sob efeito de um mesmo carregamento constante, os valores mínimos e máximos de cada ensaio foram representados nas Figuras 4-11 e 4-12. Estas figuras mostram claramente que quanto maior é o carregamento, mais influente é a fluência do material. Mesmo assim, a deformação ocorre milimetricamente e a velocidade da deformação é extremamente lenta com o decorrer do tempo. 


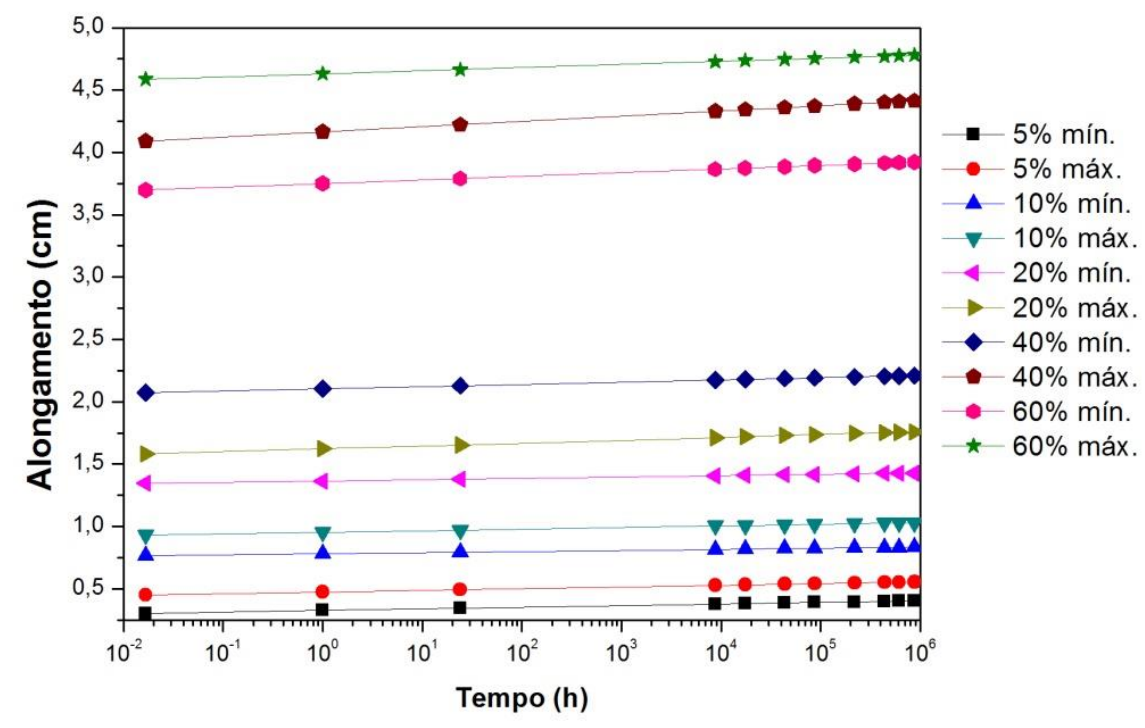

Figura 4-11 - Deformação do GTnwS.

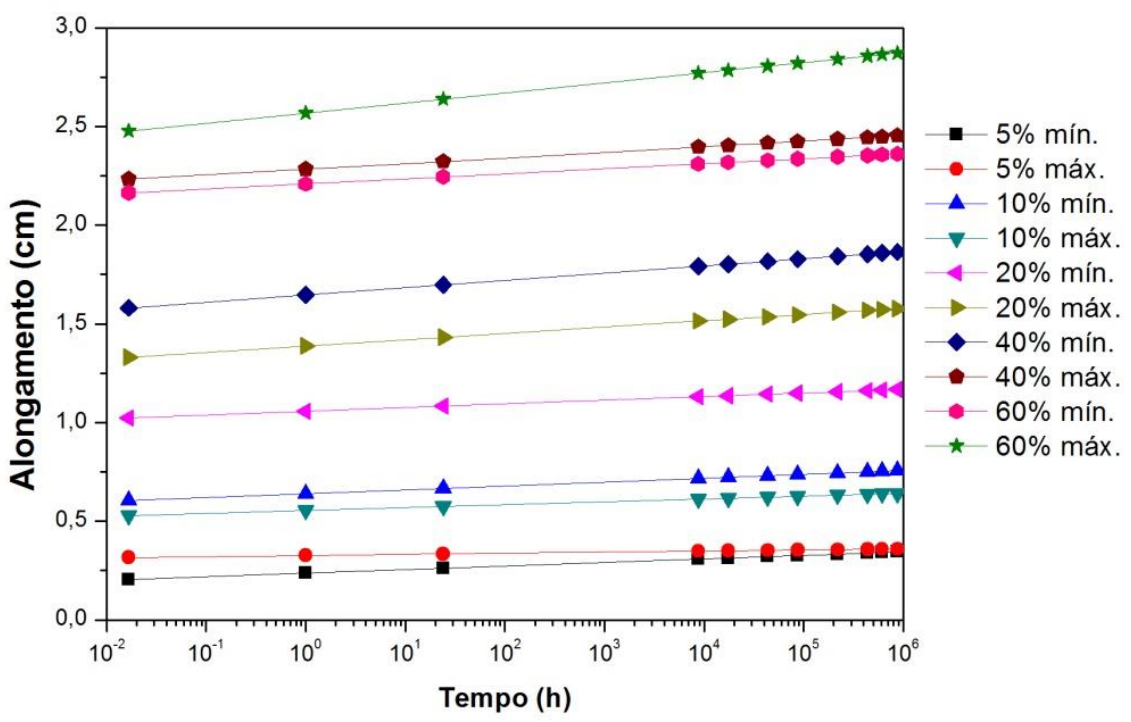

Figura 4-12 - Deformação do GTnwL.

O maior impacto sofrido pelo geotêxtil é evidenciado pela deformação inicial, assim como ilustrado pela Figura 4-13. O material solicitado sofre uma recomposição física da estrutura interna diminuindo o vazio entre as fibras, simultaneamente ao arranjo estrutural, o geotêxtil apresenta um alongamento mecânico de suas fibras, dando início ao fenômeno da fluência. Quanto maior é o carregamento, maior é a deformação inicial sofrida pelo material. 
De acordo com CAFFUZZI (1997) e DEN HOEDT (1986), como mostra a Figura 2-1, foi observado na Figura 4-13 a pequena variação da deformação por fluência do geotêxtil não tecido de poliéster, seja ele fabricado com fibras curtas ou contínuas.

a)

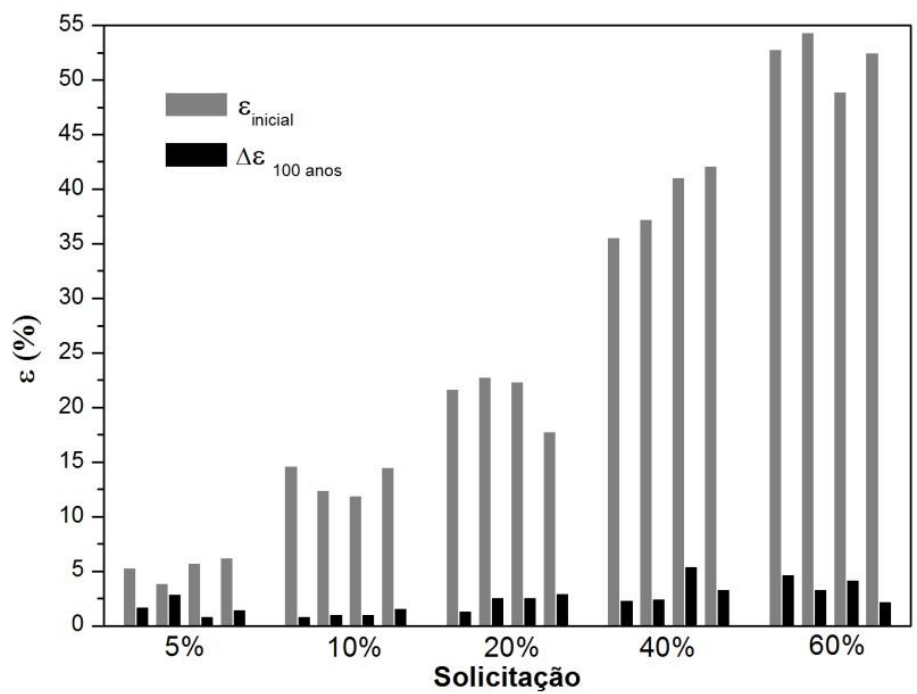

b)

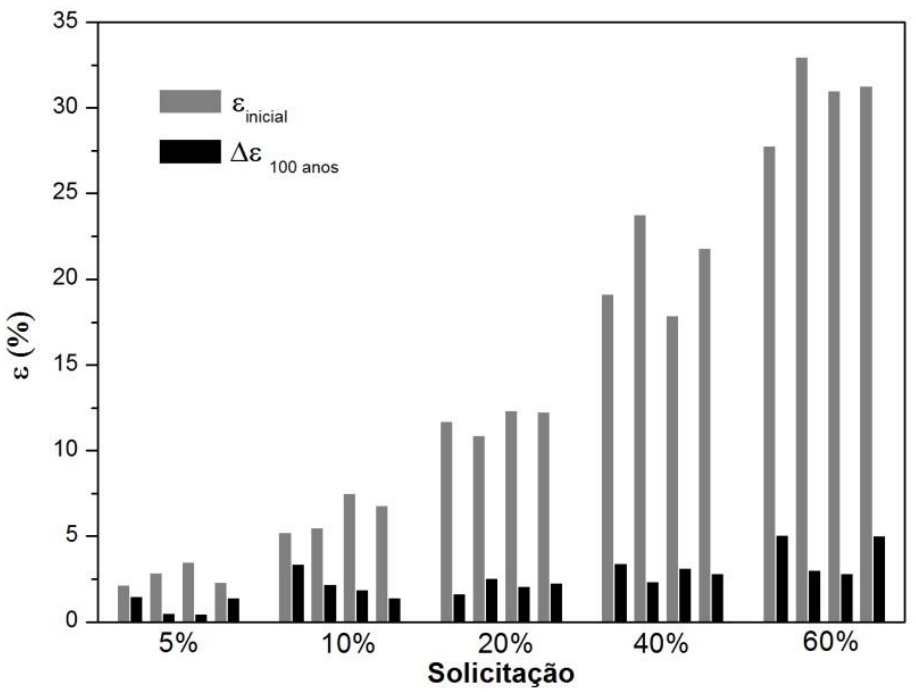

Figura 4-13 - a) GTnwS, b) GTnwL.

Para solicitações pequenas como o carregamento de 5\%, nota-se que a deformação ocorre apenas pelo rearranjo das fibras nos vazios do material, causando uma deformação inicial mínima, e o alongamento com o passar do tempo é composto por um misto entre fluência do material e reajuste dos espaços vazios. 
Quando analisamos o comportamento do material para altas solicitações, é possível notar que o geotêxtil reestrutura suas fibras imediatamente, diminuindo drasticamente o espaço vazio entre fibras, e a deformação que ocorre imediatamente ao carregamento inicial, é composto basicamente pelo fenômeno da fluência agindo sobre o composto polimérico.

Para altos carregamentos, o geotêxtil apresenta grande variação do alcance das deformações iniciais, os valores máximos do carregamento de $40 \%$ chegam a ser superiores aos valores mínimos encontrados para o carregamento de $60 \%$. Neste caso, assim como observado por Zornberg (2004), pode-se inferir que o geotêxtil demonstra uma falha estrutural, onde não ocorre a ruptura do material, mas sim uma mudança de comportamento de resposta a solicitação imposta, criando uma aleatoriedade de valores.

Quando comparamos os resultados obtidos entre os dois tipos de materiais, observa-se que o geotêxtil de filamento contínuo apresenta deformação equivalente à metade da deformação sofrida pelo geotêxtil de fibra curta, para uma mesma solicitação.

Para obras onde os recalques (deformação inicial e a fluência) seriam os limitantes de projeto, o material composto por filamento contínuo torna-se uma opção mais segura. Em contrapartida, o material de fibra curta apresentou valores de resistência total a tração menores, porém mais homogêneos, sendo indicados para obras onde a solicitação imposta seria o fator determinante para sua escolha.

As Tabelas 4-3, 4-4, 4-5 e 4-6 demonstram os resultados obtidos para as deformações dos produtos em alguns tempos pré-determinados de acordo com o tipo de obra, temporária ou permanente, e a amplitude da solicitação imposta ao geossintético. 
Tabela 4-3 - Resultados de alongamento (cm) de fluência do GTnwS.

\begin{tabular}{c|c|c|c|c|c|c|c|c|c|c|c}
\cline { 2 - 11 } & \multicolumn{3}{c}{ Tempo } & \multicolumn{10}{c}{ Tempo (anos) } \\
\cline { 2 - 13 } Carga & $0,017 \mathrm{~h}$ & $1 \mathrm{~h}$ & 1 dia & 1 & 2 & 5 & 10 & 25 & 50 & 70 & 100 \\
\hline $1-5 \%$ & 0,304 & 0,327 & 0,344 & 0,377 & 0,381 & 0,386 & 0,390 & 0,395 & 0,398 & 0,400 & 0,402 \\
$2-5 \%$ & 0,253 & 0,297 & 0,331 & 0,394 & 0,401 & 0,411 & 0,418 & 0,428 & 0,436 & 0,439 & 0,443 \\
$3-5 \%$ & 0,467 & 0,483 & 0,495 & 0,518 & 0,520 & 0,524 & 0,527 & 0,530 & 0,533 & 0,534 & 0,536 \\
$4-5 \%$ & 0,451 & 0,475 & 0,494 & 0,528 & 0,532 & 0,538 & 0,542 & 0,547 & 0,551 & 0,553 & 0,555 \\
\hline $1-10 \%$ & 0,873 & 0,884 & 0,893 & 0,910 & 0,912 & 0,914 & 0,916 & 0,919 & 0,921 & 0,922 & 0,923 \\
$2-10 \%$ & 0,843 & 0,859 & 0,872 & 0,895 & 0,897 & 0,901 & 0,904 & 0,907 & 0,910 & 0,911 & 0,912 \\
$3-10 \%$ & 0,768 & 0,783 & 0,795 & 0,816 & 0,819 & 0,822 & 0,825 & 0,828 & 0,831 & 0,832 & 0,833 \\
$4-10 \%$ & 0,930 & 0,953 & 0,970 & 1,004 & 1,008 & 1,013 & 1,017 & 1,022 & 1,026 & 1,028 & 1,030 \\
\hline $1-20 \%$ & 1,345 & 1,364 & 1,379 & 1,407 & 1,410 & 1,415 & 1,418 & 1,422 & 1,426 & 1,427 & 1,429 \\
$2-20 \%$ & 1,582 & 1,623 & 1,655 & 1,713 & 1,720 & 1,729 & 1,736 & 1,746 & 1,752 & 1,756 & 1,759 \\
$3-20 \%$ & 1,391 & 1,428 & 1,457 & 1,511 & 1,517 & 1,525 & 1,532 & 1,540 & 1,546 & 1,549 & 1,553 \\
$4-20 \%$ & 1,257 & 1,305 & 1,342 & 1,411 & 1,419 & 1,430 & 1,438 & 1,449 & 1,457 & 1,461 & 1,465 \\
\hline $1-40 \%$ & 2,554 & 2,592 & 2,622 & 2,676 & 2,683 & 2,691 & 2,698 & 2,706 & 2,713 & 2,716 & 2,719 \\
$2-40 \%$ & 2,074 & 2,105 & 2,130 & 2,175 & 2,181 & 2,188 & 2,193 & 2,200 & 2,205 & 2,208 & 2,211 \\
$3-40 \%$ & 3,274 & 3,373 & 3,451 & 3,595 & 3,611 & 3,634 & 3,651 & 3,673 & 3,690 & 3,698 & 3,707 \\
$4-40 \%$ & 4,090 & 4,164 & 4,222 & 4,330 & 4,343 & 4,359 & 4,372 & 4,389 & 4,401 & 4,407 & 4,414 \\
\hline $1-60 \%$ & 3,734 & 3,810 & 3,869 & 3,978 & 3,991 & 4,008 & 4,021 & 4,038 & 4,051 & 4,057 & 4,064 \\
$2-60 \%$ & 3,699 & 3,750 & 3,791 & 3,865 & 3,874 & 3,885 & 3,894 & 3,906 & 3,915 & 3,919 & 3,923 \\
$3-60 \%$ & 3,627 & 3,698 & 3,754 & 3,857 & 3,869 & 3,885 & 3,897 & 3,913 & 3,925 & 3,931 & 3,937 \\
$4-60 \%$ & 4,587 & 4,631 & 4,665 & 4,729 & 4,737 & 4,747 & 4,754 & 4,764 & 4,772 & 4,775 & 4,779 \\
\hline
\end{tabular}

Tabela 4-4 - Resultados de deformação por fluência (\%) do GTnwS.

\begin{tabular}{|c|c|c|c|c|c|c|c|c|c|c|c|}
\hline \multirow[b]{2}{*}{ Carga } & \multicolumn{3}{|c|}{ Tempo } & \multicolumn{8}{|c|}{ Tempo (anos) } \\
\hline & $0,017 \mathrm{~h}$ & $1 \mathrm{~h}$ & $1 \mathrm{dia}$ & 1 & 2 & 5 & 10 & 25 & 50 & 70 & 100 \\
\hline $1-5 \%$ & 5,279 & 5,673 & 5,979 & 6,547 & 6,613 & 6,701 & 6,768 & 6,856 & 6,923 & 6,955 & 6,990 \\
\hline $2-5 \%$ & 3,864 & 534 & 5,053 & 6,018 & 6,131 & 6,281 & 6,394 & 6,544 & 6,657 & 6,712 & 6,771 \\
\hline $3-5 \%$ & 5,701 & 94 & 6,044 & 6,323 & 6,355 & 6,399 & 6,431 & 6,475 & 6,507 & 6,523 & 6,540 \\
\hline $4-5 \%$ & 6,199 & 6,530 & 6,788 & 7,266 & 7,322 & 7,396 & 7,452 & 7,526 & 7,583 & 7,610 & 7,639 \\
\hline $1-10 \%$ & 14,615 & 14,806 & 14,954 & 15,230 & 15,262 & 15,305 & 15,337 & 15,380 & 15,413 & 15,428 & 15,445 \\
\hline $2-10 \%$ & 12,405 & 12,639 & 12,820 & 13,157 & 13,197 & 13,249 & 13,289 & 13,341 & 13,381 & 13,400 & 13,420 \\
\hline $3-10 \%$ & 11,910 & 2,144 & 12,325 & 12,662 & 12,702 & 12,754 & 12,794 & 12,846 & 12,886 & 12,905 & 12,925 \\
\hline $4-10 \%$ & 14,482 & 14,841 & 15,119 & 15,636 & 15,697 & 15,777 & 15,838 & 15,918 & 15,979 & 16,008 & 16,040 \\
\hline $1-20 \%$ & 21,664 & 975 & 2,216 & 22,664 & 22,717 & 22,786 & 22,839 & 22,908 & 22,961 & 22,986 & 23,014 \\
\hline $2-20 \%$ & 22,756 & 23,343 & 23,799 & 24,645 & 24,744 & 24,876 & 24,975 & 25,106 & 25,206 & 25,254 & 25,305 \\
\hline $3-20 \%$ & 22,313 & 22,912 & 23,377 & 24,239 & 24,341 & 24,474 & 24,576 & 24,710 & 24,811 & 24,860 & 24,912 \\
\hline $4-20 \%$ & 17,762 & 18,440 & 18,967 & 19,944 & 20,059 & 20,211 & 20,326 & 20,478 & 20,592 & 20,648 & 20,707 \\
\hline $1-40 \%$ & 35,556 & 36,085 & 36,495 & 37,257 & 37,346 & 37,465 & 37,554 & 37,673 & 37,762 & 37,805 & 37,851 \\
\hline $2-40 \%$ & 37,234 & 37,801 & 38,241 & 39,059 & 39,155 & 39,282 & 39,378 & 39,505 & 39,601 & 39,648 & 39,697 \\
\hline $3-40 \%$ & 41,070 & 42,322 & 43,294 & 45,097 & 45,309 & 45,589 & 45,801 & 46,081 & 46,293 & 46,396 & 46,505 \\
\hline $4-40 \%$ & 42,072 & 42,840 & 43,436 & 44,542 & 44,672 & 44,844 & 44,974 & 45,146 & 45,276 & 45,339 & 45,406 \\
\hline $1-60 \%$ & 52,764 & 53,840 & 54,675 & 56,225 & 56,407 & 56,648 & 56,830 & 57,070 & 57,252 & 57,341 & 57,435 \\
\hline $2-60 \%$ & 54,339 & 55,100 & 55,690 & 56,787 & 56,915 & 57,086 & 57,215 & 57,385 & 57,514 & 57,576 & 57,642 \\
\hline $3-60 \%$ & 48,864 & 49,828 & 50,576 & 51,965 & 52,128 & 52,344 & 52,507 & 52,723 & 52,886 & 52,965 & 53,049 \\
\hline $4-60 \%$ & 52,445 & 52,952 & 53,345 & 54,076 & 54,162 & 54,275 & 54,361 & 54,474 & 54,560 & 54,602 & 54,646 \\
\hline
\end{tabular}


Observando as Tabelas 4-3 a 4-6 fica claro a evolução da fluência agindo sobre o geossintético. Outro ponto a ser observado é a amplitude da deformação inicial, e o padrão de proporcionalidade da deformação pelo carregamento imposto, demonstrando que quando dobramos o carregamento, a deformação inicial tende a apresentar o dobro de desuniformidade, independente do tipo de geotêxtil analisado.

Tabela 4-5 - Resultados de alongamento (cm) de fluência do GTnwL.

\begin{tabular}{c|c|c|c|c|c|c|c|c|c|c|c}
\cline { 2 - 11 } & \multicolumn{3}{c}{ Tempo } & \multicolumn{10}{c}{ Tempo (anos) } \\
\cline { 2 - 12 } Carga & $0,017 \mathrm{~h}$ & $1 \mathrm{~h}$ & 1 dia & 1 & 2 & 5 & 10 & 25 & 50 & 70 & 100 \\
\hline $1-5 \%$ & 0,205 & 0,237 & 0,262 & 0,308 & 0,314 & 0,321 & 0,327 & 0,334 & 0,339 & 0,342 & 0,345 \\
$2-5 \%$ & 0,259 & 0,269 & 0,277 & 0,292 & 0,294 & 0,296 & 0,298 & 0,300 & 0,302 & 0,302 & 0,303 \\
$3-5 \%$ & 0,317 & 0,327 & 0,335 & 0,349 & 0,351 & 0,353 & 0,355 & 0,357 & 0,358 & 0,359 & 0,360 \\
$4-5 \%$ & 0,222 & 0,253 & 0,277 & 0,322 & 0,328 & 0,335 & 0,340 & 0,347 & 0,352 & 0,355 & 0,358 \\
\hline $1-10 \%$ & 0,403 & 0,463 & 0,509 & 0,596 & 0,606 & 0,619 & 0,629 & 0,643 & 0,653 & 0,658 & 0,663 \\
$2-10 \%$ & 0,492 & 0,537 & 0,572 & 0,637 & 0,645 & 0,655 & 0,663 & 0,673 & 0,681 & 0,684 & 0,688 \\
$3-10 \%$ & 0,606 & 0,640 & 0,667 & 0,718 & 0,723 & 0,731 & 0,737 & 0,745 & 0,751 & 0,754 & 0,757 \\
$4-10 \%$ & 0,530 & 0,555 & 0,575 & 0,612 & 0,616 & 0,622 & 0,626 & 0,632 & 0,636 & 0,638 & 0,640 \\
\hline $1-20 \%$ & 1,024 & 1,057 & 1,083 & 1,131 & 1,136 & 1,144 & 1,149 & 1,157 & 1,162 & 1,165 & 1,168 \\
$2-20 \%$ & 1,059 & 1,115 & 1,159 & 1,241 & 1,250 & 1,263 & 1,272 & 1,285 & 1,295 & 1,299 & 1,304 \\
$3-20 \%$ & 1,112 & 1,155 & 1,188 & 1,249 & 1,257 & 1,266 & 1,274 & 1,283 & 1,290 & 1,294 & 1,298 \\
$4-20 \%$ & 1,332 & 1,389 & 1,433 & 1,514 & 1,524 & 1,537 & 1,546 & 1,559 & 1,568 & 1,573 & 1,578 \\
\hline $1-40 \%$ & 1,581 & 1,646 & 1,697 & 1,791 & 1,802 & 1,816 & 1,827 & 1,842 & 1,853 & 1,858 & 1,864 \\
$2-40 \%$ & 2,233 & 2,283 & 2,323 & 2,396 & 2,404 & 2,416 & 2,424 & 2,436 & 2,444 & 2,448 & 2,453 \\
$3-40 \%$ & 1,758 & 1,829 & 1,884 & 1,986 & 1,998 & 2,014 & 2,026 & 2,042 & 2,054 & 2,059 & 2,066 \\
$4-40 \%$ & 2,132 & 2,195 & 2,244 & 2,336 & 2,347 & 2,361 & 2,372 & 2,386 & 2,397 & 2,402 & 2,408 \\
\hline $1-60 \%$ & 2,245 & 2,339 & 2,413 & 2,548 & 2,564 & 2,585 & 2,601 & 2,622 & 2,638 & 2,646 & 2,654 \\
$2-60 \%$ & 2,247 & 2,294 & 2,331 & 2,398 & 2,406 & 2,417 & 2,425 & 2,435 & 2,443 & 2,447 & 2,451 \\
$3-60 \%$ & 2,164 & 2,209 & 2,245 & 2,310 & 2,318 & 2,328 & 2,336 & 2,346 & 2,354 & 2,357 & 2,361 \\
$4-60 \%$ & 2,476 & 2,568 & 2,638 & 2,770 & 2,785 & 2,806 & 2,821 & 2,842 & 2,857 & 2,865 & 2,873 \\
\hline
\end{tabular}

Outro método para interpretar a variabilidade dos dados obtidos e que estão exemplificados nas tabelas anteriores é através do coeficiente de variação, que quantifica a variabilidade em relação à média dos dados. Quanto menor for o coeficiente mais homogêneo é o conjunto de dados. O coeficiente de variação é geralmente aplicado para avaliar resultados que envolvem a mesma variável-resposta, permitindo quantificar a precisão dos ensaios e seus resultados. 
Tabela 4-6 - Resultados de deformação por fluência (\%) do GTnwL.

\begin{tabular}{|c|c|c|c|c|c|c|c|c|c|c|c|}
\hline \multirow[b]{2}{*}{ Carga } & \multicolumn{3}{|c|}{ Tempo } & \multicolumn{8}{|c|}{ Tempo (anos) } \\
\hline & $0,017 \mathrm{~h}$ & $1 \mathrm{~h}$ & 1 dia & 1 & 2 & 5 & 10 & 25 & 50 & 70 & 100 \\
\hline $1-5 \%$ & 2,143 & 2,480 & 2,742 & 3,228 & 3,285 & 3,361 & 3,418 & 3,493 & 3,550 & 3,578 & 3,608 \\
\hline $5 \%$ & 2,836 & 18 & 3,035 & 196 & 215 & 3,240 & & 34 & ,303 & 312 & 322 \\
\hline $3-5 \%$ & 3,474 & ,582 & 3,666 & 3,822 & 3,840 & 3,864 & 3,883 & 3,907 & 3,925 & ,934 & ,943 \\
\hline $4-5 \%$ & 2,313 & 2,639 & 2,892 & 3,361 & 3,416 & 3,489 & 3,544 & 3,617 & 3,673 & 3,699 & 3,728 \\
\hline $1-10 \%$ & 5,224 & 6,003 & 6,608 & 7,730 & 7,862 & 8,036 & 8,168 & 8,342 & 8,474 & 8,538 & 8,606 \\
\hline $2-10 \%$ & 5,477 & 5,980 & 6,371 & 7,097 & 7,182 & 7,295 & 7,380 & 7,493 & 7,578 & 7,620 & 7,663 \\
\hline $3-10 \%$ & 7,496 & 7,926 & 8,260 & 8,880 & 8,953 & 9,049 & 9,122 & 9,218 & 9,291 & 9,327 & 9,364 \\
\hline $4-10 \%$ & 6,777 & 7,103 & 7,356 & 7,825 & 7,880 & 7,953 & 8,008 & 8,080 & 8,136 & 8,162 & 8,191 \\
\hline $1-20 \%$ & 02 &, 080 & 2,373 & 2,918 & 12,982 & 13,066 & 13,130 & 13,215 & 13,279 & 13,310 & 13,343 \\
\hline $2-20 \%$ & 882 & 11,463 & ,914 & 12,751 & 12,850 & 12,980 & 13,078 & 13,208 & 13,306 & 13,354 & 13,405 \\
\hline $3-20 \%$ & 12,337 & 12,812 & 13,181 & 13,865 & 13,945 & 14,052 & 14,132 & 14,238 & 14,319 & 14,358 & 14,399 \\
\hline $4-20 \%$ & 12,259 & 12,780 & 13,185 & 13,936 & 14,024 & 14,141 & 14,229 & 14,345 & 14,434 & 14,476 & 14,522 \\
\hline $1-40 \%$ & 19,131 & 19,920 & 20,532 & 21,668 & 21,802 & 21,978 & 22,112 & 22,288 & 22,422 & 22,487 & 22,555 \\
\hline $2-40 \%$ & 23,771 & 24,311 & 24,730 & 25,507 & 25,599 & 25,720 & 25,811 & 25,932 & 26,023 & 26,067 & 26,114 \\
\hline $3-40 \%$ & 17,879 & 18,600 & 19,160 & 20,200 & 20,322 & 20,483 & 20,605 & 20,767 & 20,889 & 20,948 & 21,011 \\
\hline $4-40 \%$ & 21,808 & 22,458 & 22,963 & 23,900 & 24,010 & 24,155 & 24,265 & 24,411 & 24,521 & 24,574 & 24,631 \\
\hline $1-60 \%$ & 27,755 & 28,920 & 29,824 & 31,503 & 31,700 & 31,961 & 32,158 & 32,418 & 32,616 & 32,711 & 32,813 \\
\hline $2-60 \%$ & 32,980 & 33,670 & 34,206 & 35,201 & 35,317 & 35,472 & 35,589 & 35,743 & 35,860 & 35,917 & 35,977 \\
\hline $3-60 \%$ & 30,990 & 31,642 & 32,148 & 33,087 & 33,198 & 33,343 & 33,454 & 33,600 & 33,710 & 33,764 & 33,820 \\
\hline $4-60 \%$ & 31,253 & 32,405 & 33,299 & 34,959 & 35,154 & 35,411 & 35,606 & 35,864 & 36,059 & 36,154 & 36,254 \\
\hline
\end{tabular}

A Figura 4-13 quantifica os coeficientes de variação dos dois geotexteis pesquisados. É notável que quanto menor a carga aplicada, maior é a variação destes coeficientes. Isto pode fundamentar a teoria de que, para pequenos carregamentos, ocorre a recomposição fisica do material através da diminuição de espaços vazios entre as fibras e filamentos. 
a)

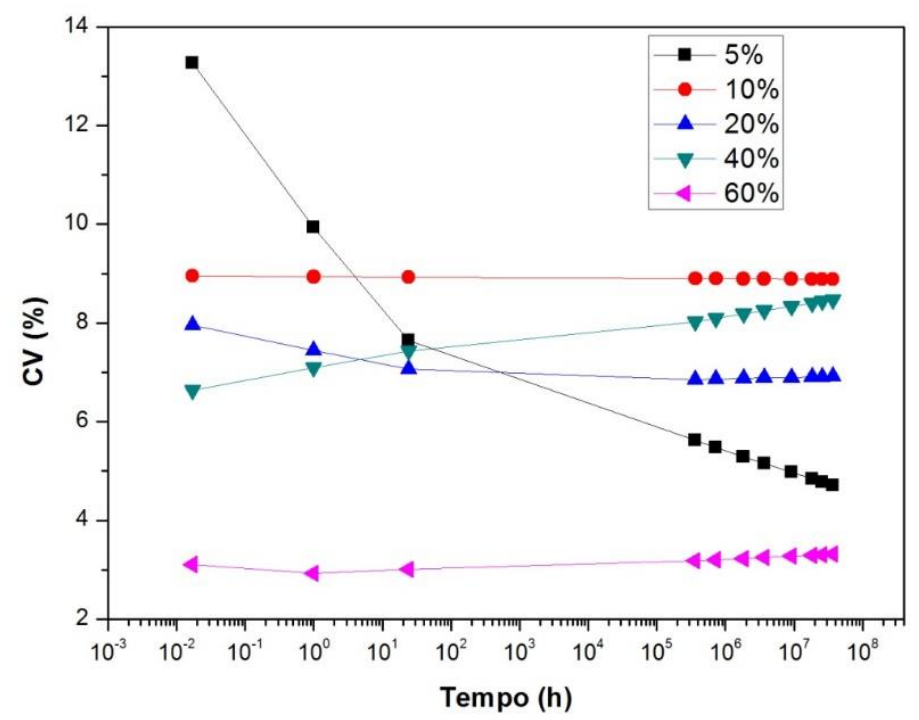

b)

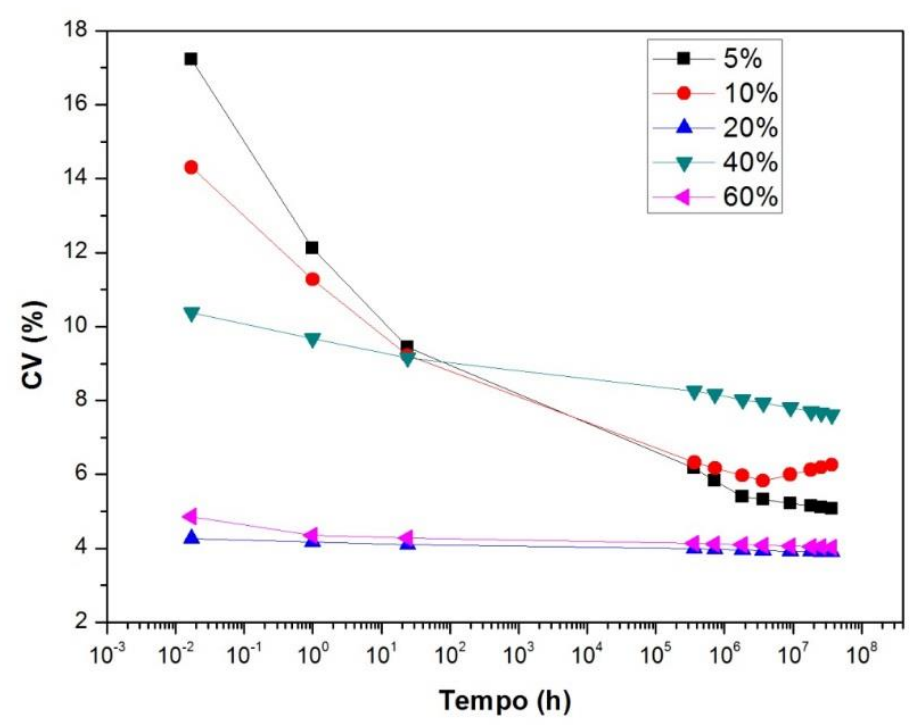

Figura 4-13 - Coeficiente de variação - a) GTnwL, b) GTnwS.

Utilizando a Figura 4-13 outra constatação fica evidente. De acordo com estes resultados, observa-se claramente uma tendência de estabilização dos coeficientes de variação da fluência para longos períodos. Assim, pode-se inferir que para os tempos iniciais de ensaio, a deformação observada no material, é em grande proporcionalidade causada pelo rearranjo das fibras no geotêxtil.

O geotêxtil de fibra curta, comparado-o com o de filamento contínuo, apresentou maior coeficiente de variação com maior amplitude de variabilidade do coeficiente de variação com o tempo. Verifica-se que os dois materiais apresentam comportamento 
idênticos quando a solicitação é de 5\%, demonstrando valores de coeficientes de variação diminuindo pela metade com o passar do tempo.

\subsection{ISÓCRONAS}

A relação entre o carregamento do corpo de prova e a deformação especifica é conhecido como Módulo de Fluência (ou módulo de deformação). As características viscoelásticas influenciam no valor do módulo de fluência durante todo o tempo de solicitação do ensaio. Esta deformação por unidade de tensão relacionada ao tempo demonstra a variação do módulo de rigidez do material.

A partir dos valores medidos para deformação dos corpos de prova em função do tempo, determinou-se os módulos de fluência dos dois materiais. A Figura 4-14 ilustra o módulo de deformação do material GTnwS, os resultados encontrados para o material GTnwL estão exemplificados na Figura 4-15.

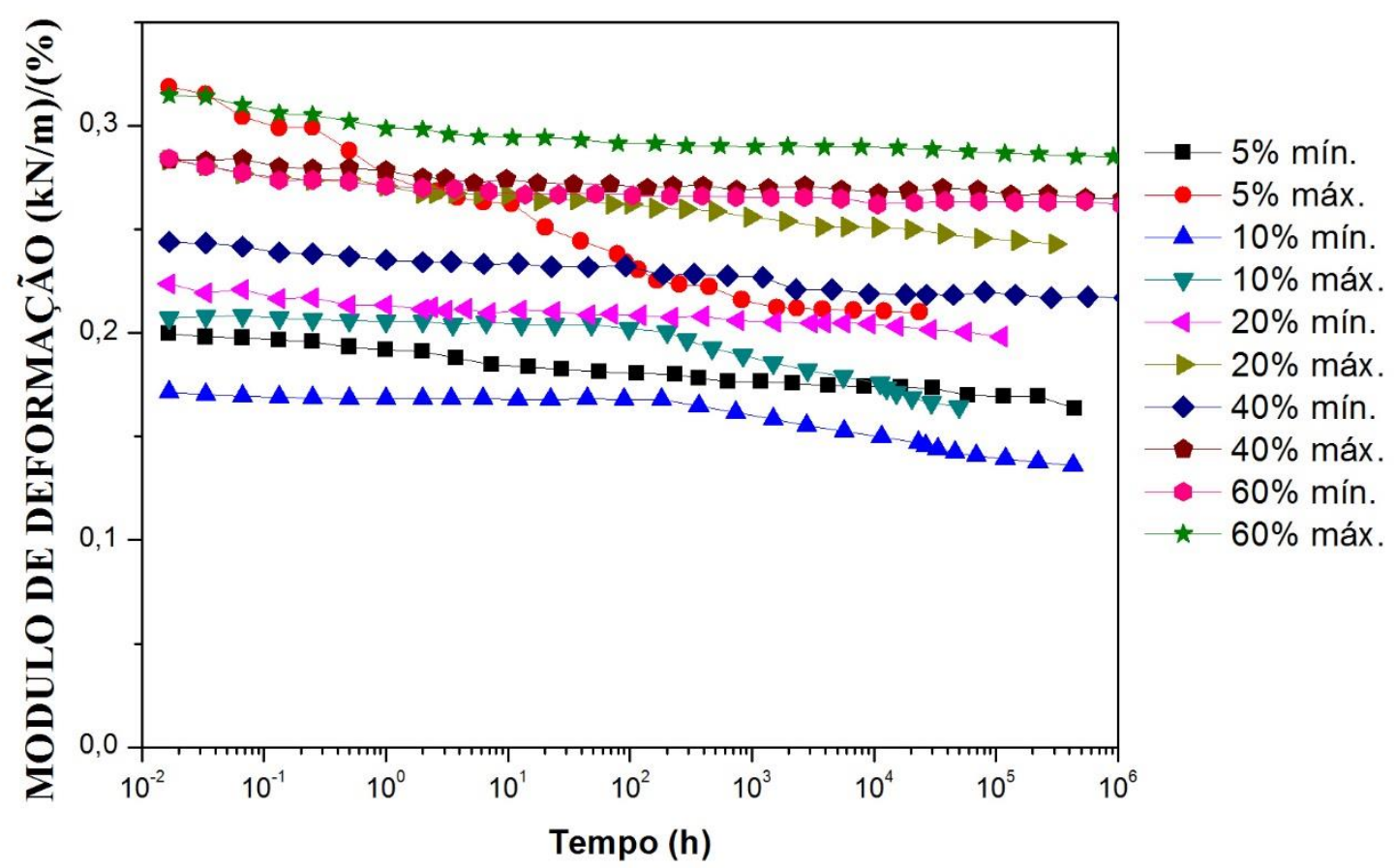

Figura 4-14 - Módulo de deformação - GTnwS. 


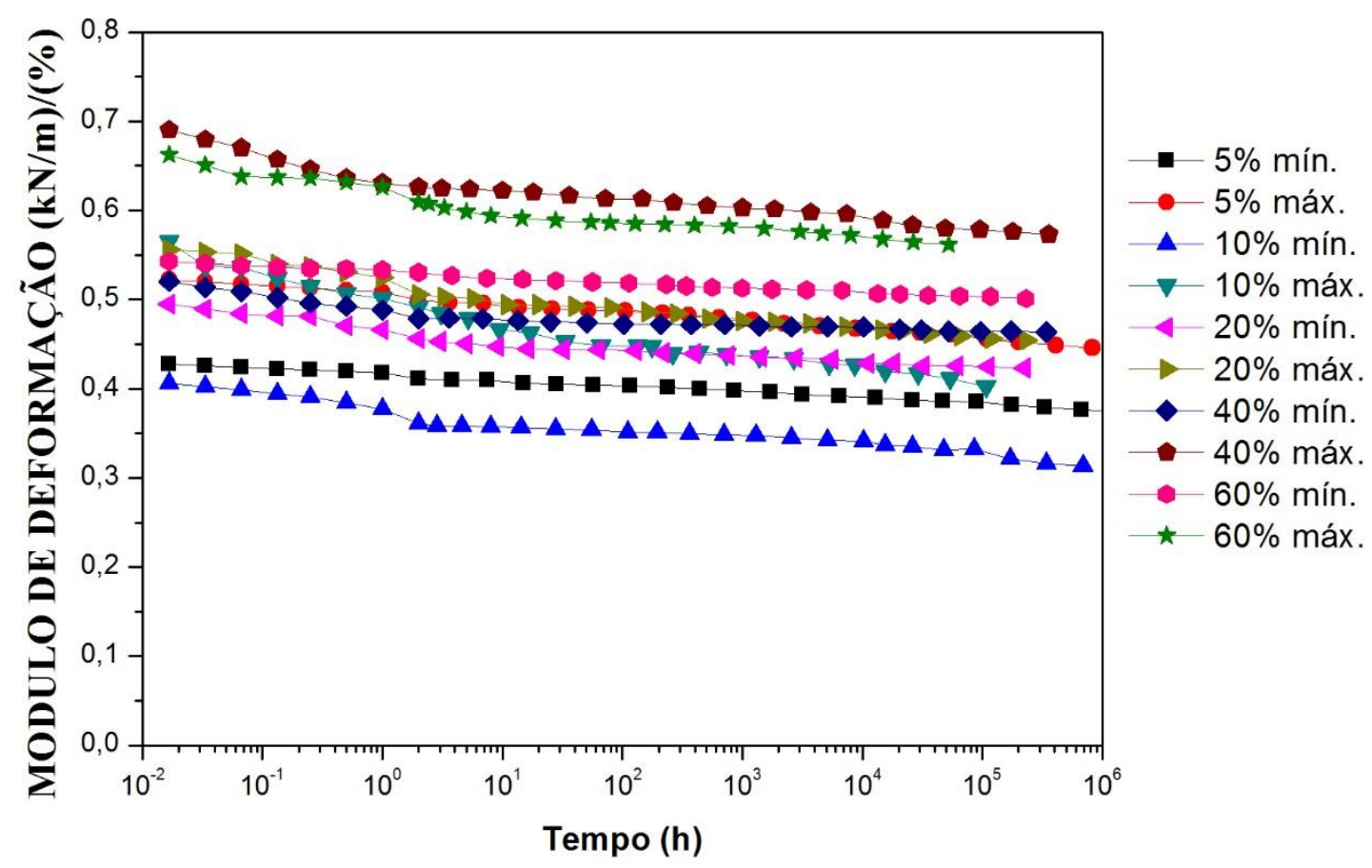

Figura 4-15 - Módulo de deformação - GTnwL.

Foram demonstrados os resultados que apresentaram respectivamente máximo e mínimo de deformação para cada patamar de solicitação imposta, tanto para o material composto por fibra curta, bem como o material de filamento continuo.

O material de GTnwL apresenta módulo de fluência maior que o GTnwS, isto é relacionado a uma resistência maior a tração combinado com valores de deformação menores que os encontrados nos corpos de prova do geotêxtil de fibra curta.

O geotêxtil de filamento continuo demonstrou, em todos os ensaios de fluência, sempre deformações iniciais menores que o geotêxtil de fibra curta, por isso o módulo de deformação do GTnwL apresenta resultados mais homogêneos e curvas com inclinações menores que a do GTnwS.

Outra forma de analisar os resultados encontrados é através das curvas isócronas, sendo esta, uma relação entre a solicitação aplicada e a deformação do material para tempos pré determinados. A Figura 4-16 ilustra a formação das curvas isócronas através dos pares de pontos de deformação por fluência do material GTnwS, os resultados encontrados para o material GTnwL estão exemplificados na Figura 4-17.

Analisando os resultados obtidos pelas isócronas, percebe-se que o material apresenta uma perda de rigidez referente à solicitação permanente da carga por um longo período de tempo, porém esta diminuição da rigidez apresenta pequena magnitude 
se comparado aos resultados da deformação instantânea. Esta baixa perda de rigidez é uma característica de materiais constituídos de poliéster (PET), sendo esta característica notada tanto para o material de GTnwS quanto para o material GTnwL.

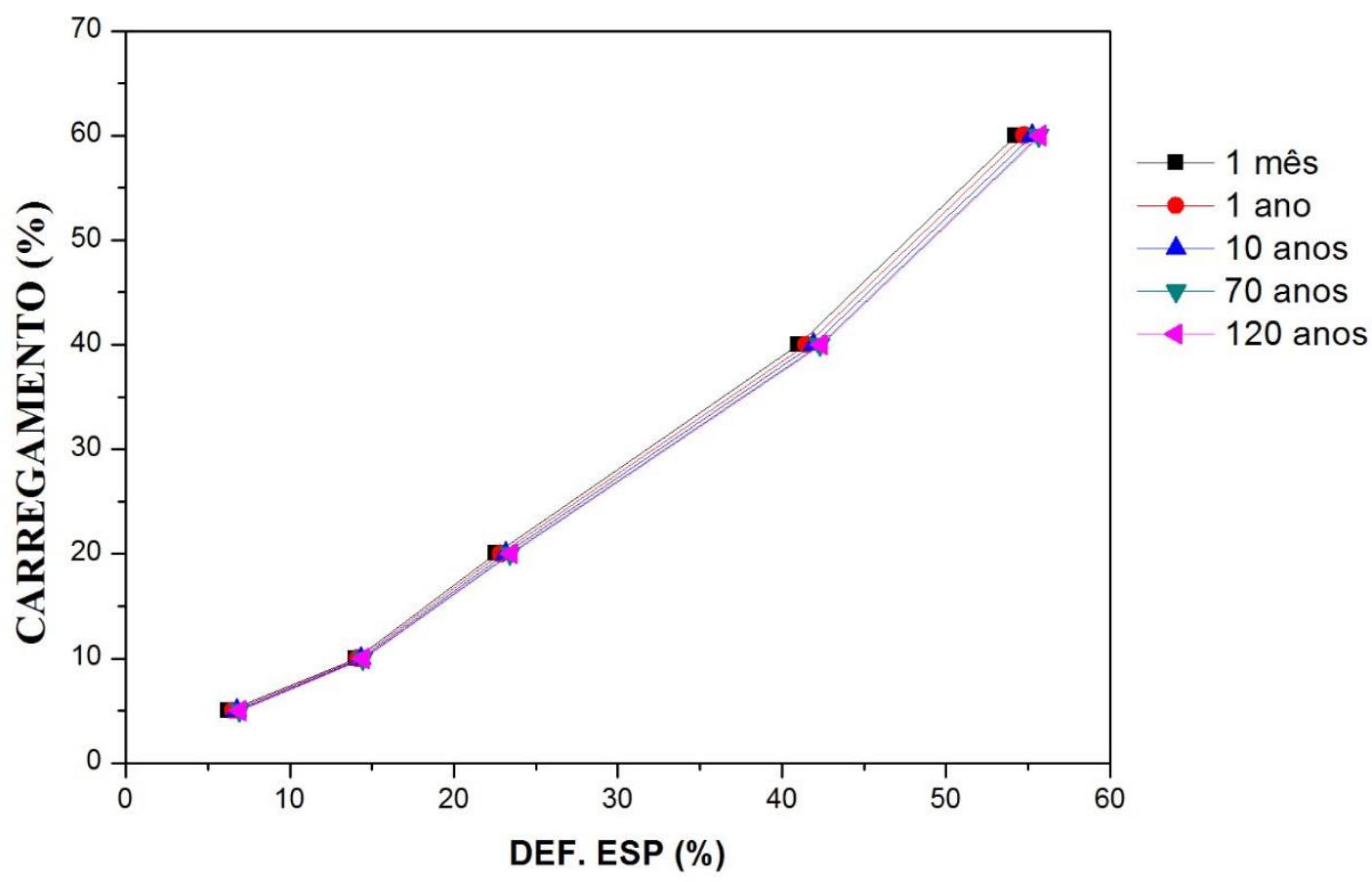

Figura 4-16 - Curva Isócrona - GTnwS. 


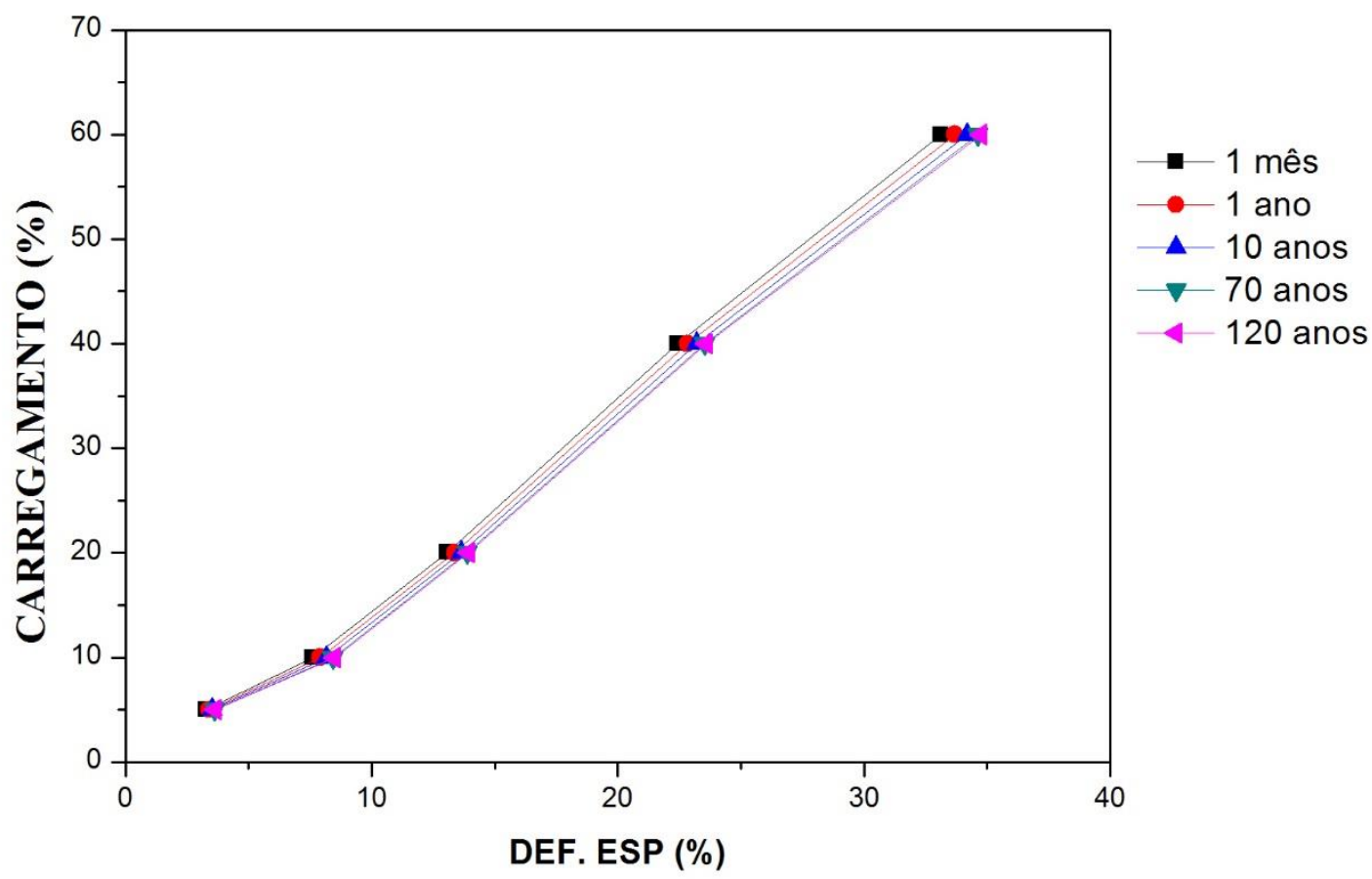

Figura 4-17 - Curva Isócrona - GTnwL. 


\section{CONCLUSÃO E SUGESTÕES}

Esta dissertação apresentou um estudo sobre a fluência não confinada de dois geotêxteis não tecidos de poliéster por meio de ensaios convencionais e acelerados (SIM). Para isto, foi implementado um novo equipamento para a realização do ensaio SIM no Laboratório de Geossintéticos da EESC-USP.

A pesquisa foi conduzida em 4 principais etapas, sendo estas a caracterização do material, ensaios de tração máxima em faixa larga, ensaios convencionais e ensaios acelerados pelo método SIM. As análises de fluência foram baseadas em métodos já consagrados e pesquisas anteriores serviram como base de dados para comparação.

O geotêxtil de fibra curta apresentou valores de deformação por são satisfatórios, pois as previsões de alcances das curvas pelo método SIM foram de até 355 anos e estão relativamente próximos aos valores indicados por Thornton (1998).

O geotêxtil de filamentos contínuos demonstrou uma resistência maior quanto à deformação inicial, se comparado ao material semelhante estudado por Baras (2001), pois os valores de deformação encontrados nesta pesquisa são sempre menores que os valores explicitados por Baras (2001). Outra constatação foi que o tempo de resposta das curvas de fluência demonstraram alcances próximos a 100 anos, e maior homogeneidade com menor deformação se comparado ao material de fibra curta.

Verificou-se que a escolha realizada da inclinação da curva ao encontrar o tempo virtual é a causa da variabilidade que ocorre entre os alcances. Os diferentes resultados encontrados para as deformações tem influência direta do processo de fabricação do material e da heterogeneidade entre as amostras analisadas.

Os valores de deformação obtidos pelo método SIM demonstraram boa convergência com os resultados encontrados pelo método convencional, porém os coeficientes angulares encontrados nesta pesquisa não apresentavam valores semelhantes (para um mesmo carregamento) como era o esperado, demonstrando que o material ainda apresenta variabilidade inerente, conforme já foi constatado na literatura, e constatando que o ensaio acelerado deve ser utilizado como artifício de controle rápido da qualidade do material, porem sempre que necessário e possível deverá ser 
considerado o ensaio convencional como o principal parâmetro para dados de projeto confiáveis.

Assim como mostrou outros autores como CAFFUZZI (1997) e DEN HOEDT (1986), os geotêxteis não tecidos de poliéster de fibra curta e contínua analisados nesta pesquisa apresentaram pequena variação de deformação para um tempo de 100 anos, evidenciando que para este tipo de polímero, o comportamento mecânico do geotêxtil é mais influenciado pela deformação inicial do que pela fluência.

\section{Sugestões de novos estudos}

- Analisar o efeito da distorção gerada pela realização de fotos com enquadramentos não convergentes;

- Estimar a resistência residual do material após longos períodos de ensaios de fluência por meio de ensaios de faixa larga.

- Realizar ensaios de fluência convencional com intervalos próximos a 10000 horas e compará-los com os valores obtidos através de ensaios acelerados. 


\section{REFERÊNCIAS BIBLIOGRÁFICAS}

ABRAMENTO, M. (1995). Durabilidade e comportamento de longo prazo de geossintéticos - parte I: propriedades mecânicas e hidráulicas. In: Geossintéticos'95. Anais. São Paulo, p. 217-226.

ANDRAWES, K. Z.; McGOWN, A.; KABIR MD, H. (1984). Uniaxial strength testing of woven and nonwoven geotextiles. Geotextiles and Geomembranes, 1. No. 1, 4156.

ASSOCIAÇÃO BRASILEIRA DE NORMAS TÉCNICAS (2003). NBR 12568 Geotêxteis - Determinação da massa por unidade de área.

ASSOCIAÇÃO BRASILEIRA DE NORMAS TÉCNICAS (2005). NBR 15226 Geossintéticos - Determinação do comportamento em deformação ou na ruptura, por fluência sob tração não confinada.

ASSOCIAÇÃO BRASILEIRA DE NORMAS TÉCNICAS (1992). NBR 12593 Amostragem e preparação de corpos de prova de geotêxteis. Rio de Janeiro.

ASSOCIAÇÃO BRASILEIRA DE NORMAS TÉCNICAS (1993). NBR 12824 Geotêxteis - Determinação da resistência à tração não-confinada - Ensaio de tração de faixa larga.

ASSOCIAÇÃO BRASILEIRA DE NORMAS TÉCNICAS (1993). NBR 13359 Determinação da resistência ao puncionamento estático - ensaio com pistão tipo CBR.

AMERICAN SOCIETY FOR TESTING AND MATERIALS. ASTM D3786 - 08a. Standard Test Method for Bursting Strength of Textile Fabrics - Diaphragm Bursting Strength Tester Method.

AMERICAN SOCIETY FOR TESTING AND MATERIALS. ASTM D4533 - 91. Standard Test Method for Trapezoid Tearing Strength of Geotextiles.

AMERICAN SOCIETY FOR TESTING AND MATERIALS. ASTM D4595 - 11. Standard Test Method for Tensile Properties of Geotextiles by the Wide-Width Strip Method. 
AMERICAN SOCIETY FOR TESTING AND MATERIALS. ASTM D4632 - 08.

Standard Test Method for Grab Breaking Load and Elongation of Geotextiles.

AMERICAN SOCIETY FOR TESTING AND MATERIALS. ASTM D4833 - 00.

Standard Test Method for Index Puncture Resistance of Geotextiles, Geomembranes, and Related Products.

AMERICAN SOCIETY FOR TESTING AND MATERIALS. ASTM D5262 - 07.

Standard Test Method for Evaluating the Unconfined Tension Creep and Creep Rupture Behavior of Geosynthetics. In: Annual book of ASTM standards. New York.

AMERICAN SOCIETY FOR TESTING AND MATERIALS. ASTM D6992 - 03. Standard Test Method for Accelerated Tensile Creep and Creep Rupture of Geosynthetic Materials Based on Time-Temperature Superposition Using the Stepped Isothermal Method. In: Annual book of ASTM standards. New York.

BARAS, L. C. S. (2001). Estudo da fluência em geotêxteis através de ensaios não confinados convencionais e acelerados. Dissertação de Mestrado. Escola de Engenharia de São Carlos. Universidade de São Paulo.

BATHURST, R. J.; HUANG, B.; ALLEN, T. M. (2011a). Analysis of installation damage tests for LRFD calibration of reinforced soil structures. Geotextiles and Geomembranes, 29, No. 3, 323-334.

BATHURST, R. J.; HUANG, B.; ALLEN, T. M. (2011b). Load and resistance factor design (LRFD) calibration for steel grid reinforced soil walls. Georisk, Vol. 5, Nos. 3-4, 218-228.

BATHURST, R. J.; HUANG, B.; ALLEN, T. M. (2012). Interpretation of laboratory creep testing for reliability-based analysis and load and resistance factor design (LRFD) calibration. Geosynthetics International, 19, No. 1, 3953.

BECK, A. T., Confiabilidade Estrutural. 2012. Apostila da disciplina SET-5915 Confiabilidade Estrutural - Escola de Engenharia de São Carlos - Universidade de São Paulo. 
BENJAMIM, J. R.; CORNELL, C. A. (1970). Probability, Statistics and Decision for Civil Engineers. McGraw-Hill, USA. 684p.

BENJAMIM, C. V. S. (2006), Avaliação experimental de protótipos de estruturas de contenção em solo reforçado com geotêxtil. Tese Doutorado em Geotecnia Departamento de Geotecnia, Escola de Engenharia de São Carlos, Universidade de São Paulo.

CAZZUFFI, D.; GHINELLI, A.; SACCHETTI, M.; VILLA, C. (1997). European experimental approach to the tensile creep behavior of high-strength geosynthetics. In: Geosynthetics'97. Proceedings. California. v.1, p. 253-266.

COSTA, C. M. L. (1999). Fluência em geotêxteis. São Carlos. Dissertação de Mestrado. Escola de Engenharia de São Carlos, Universidade de São Paulo.

COSTA, C. M. L. (2004). Deformações dependentes do tempo em muros de solo reforçado com geotêxteis. Tese Doutorado em Geotecnia - Departamento de Geotecnia, Escola de Engenharia de São Carlos, Universidade de São Paulo.

COSTANZI, M. A. (2003). Emprego do Método SIM para Obtenção das Curvas Isocrônas e de Ruptura por Fluência. Dissertação de Mestrado. Escola de Engenharia de São Carlos. Universidade de São Paulo.

DEN HOEDT, G. (1986). Durability of geotextiles. London, Chapman and Hall. P. 3438. Principles of creep and relaxation.

ELIAS et al (2001) - Mechanically stabilized earth walls and reinforced soil slopes design and construction guidelines. Publicação $\mathrm{n}^{\circ}$ FHWA-NHI-00-043. U.S. Department of Transportation Federal Highway Administration. Washington EUA.

FARRAG, K. Development of na Accelerated Creep Testing Procedure for Geosynthetics, Part II: Analysis. Geotechnical Testing Journal, GTJODJ, Vol 21, No. 1, March 1998, pp. 38-44.

FLUGGE, W. Viscoelasticity. Waltham, Mass.: Blaisdell Pub., 1967. 127 p. 
FRANÇA, F. A. N. Novo equipamento para realização de ensaios confinados e acelerados de fluência em geossintéticos. 2011. 259 f. Tese Doutorado, Escola de Engenharia de São Carlos, Universidade de São Paulo. 2012.

FRANÇA, F. A. N; BUENO, B. S; ZORNBERG, J. G. (2011). Ensaios Confinados e Acelerados de Fluência em Geossintéticos. Fundações e Obras Geotécnicas, p. 5663.

FREUDENTHAL, A. M. (1947). The Safety of Structural. Transactions of ASCE. Vol. 112 , p. $125-180$.

HELWANY, S. M. B.; SHIN, S. (1998). Creep and stress relaxation of geotextilereinforced soils. Geosynthetics International, v. 5, n. 4, p. 425-434.

ISO/TR 20432:2007, Guidelines for the determination of the long-term strength of geosynthetics for soil reinforcement.

KOERNER, R. M.; LORD, AE. Jr.; HALSE, Y. H. (1988). Long term durability and aging of geotextiles. Geotextiles and Geomembranes, v.7, p.147-158.

KOERNER, R. M.; SOONG, T.; KOERNER, G. R.; GONTAR, A. (2001). Creep testing and data extrapolation of reinforced GCLs. Geotextiles and Geomembranes n. 16 p. $365-382$.

LOW, B. K.; TANG, W. H. (2001). Efficient Reliability-Based Desing Using Spreadsheet Optimization. Proceedings of the Eight International Conference on Structural Safety and Reliability, ICOSSAR 01, Newport Beach, California, 17-22 June 2001.

MCGOWN, A.; ANDRAWES, K. Z.; KABIR, M. H. Load-extension testing of geotextiles confined in-soil. In: INTERNATIONAL CONFERENCE ON GEOTEXTILES, 2., 1982, Las Vegas, 1982. P 793-798.

MSOUTI, M. F.; BLIVET, J. C.; LEVACHER, D. (1987). Comportament au fluage des geotextiles en reforcemente mécanique. Etudes et recherches des laboratories des ponts et Chaussees, GT n.63.

NOWAK, A. S.; COLlinS, K. R. (2000). Reliability of Structures. Michigan: McGraw-Hill. 
REDDY, D. V.; BUTUL, B. (1999). A Comprehensive Literature Review of Liner Failures and Longevity. In: Florida Center for Solid and Hazardous Waste Management University of Florida.

ROYLANCE, D. (2001). Modulus in mechanics of materials, Massachusetts institute of technology, Cambridge, MA.

THORNTON, J. S.(1998). The stepped isothermal method (SIM) for time-temperature superposition. In: Creep and Assessment of geossynthetics for Soil Reinforcemente; Leatherhead. Proceedings. Report 98-0015.

THORNTON, J. S.; ALLEN, S. R.; THOMAS, R. W.; SANDRI, D. (1998). The Stepped Isothermal Method for Time-Temperature Superposition and Its Application to Creep Data on Polyester Yarn. In: Sixth International Conference on Geosynthetics, p.699-706.

VERTEMATTI, J. C. (2004) - Manual Brasileiro de Geossintéticos - Associação Brasileira das indústrias de não tecidos e tecidos técnicos - ABINT.

WU, J. T. H., HELWANY, S. M. B. (1996). A performance test for assessment of long term creep behavior of soil-geosynthetic composites. Geosynthetics International, v. 3, n. 1, p. 107-124.

YEO, S. S. (2007). Evaluation of Creep Behavior of Geosynthetics Using Accelerated and Conventional Method.

ZORNBERG, J, G. M.ASCE. BYLER, B, R. KNUDSEN, J, W. Creep of Geotextiles Using Time Temperature Superposition Methods. J. Geotech. Geoenviron. Eng. 2004. 130: pg 1158-1168. 